\title{
UTILIZAÇÃO DE DIFERENTES FONTES PROTÉICAS EM DIETAS FORMULADAS PELO CONCEITO DE PROTEÍNA IDEAL / PARA O "BLACK BASS" (Micropterus salmoides)
}

\author{
LEANDRo Portz M.SC. \\ Zootecnista
}

Orientador: Prof. Dr. José Eurico Possebon Cyrino

Tese apresentada à Escola Superior de Agricultura "Luiz de Queiroz", Universidade de São Paulo, para obtenção do título de Doutor em Agronomia, Área de Concentração: Ciência Animal e Pastagens.

\author{
PIRACICABA \\ Estado de São Paulo - Brasil \\ Setembro -2001
}


LEANDRO PORTZ. Utilização de diferentes fontes protéicas em dietas formuladas pelo conceito de proteína ideal para o "black bass"(Micropterus salmoides)/Tese

p. iten linha

$12 \quad 2.2 .1 .2$ décima quinta

$21 \quad 2.3 .2 \quad$ primeira

$\begin{array}{lll}21 & 2.3 .2 & \text { oitava }\end{array}$

$\begin{array}{lll}32 & 3.2 & \text { sexta }\end{array}$

$32 \quad 3.2$ décima terceira

$32 \quad 3.2 \quad$ décima quarta

33 Tabela 1 décima segunda

34 Tabela 2 vigésima primeia

$\begin{array}{lll}40 & 3.3 \quad \text { sexta }\end{array}$

$\begin{array}{lll}40 & 3.3 & \text { oitava }\end{array}$

$40 \quad 3.3 \quad$ décima nona

$45 \quad 4.1 \quad$ vigésima

$\begin{array}{lll}46 & 4.1 \quad \text { quarta }\end{array}$

49 Tabela 3 décima

49 Tabela 3 décima

55 Tabela 6 segunda

$\begin{array}{lll}58 & 4.3 \quad \text { quarta }\end{array}$

$\begin{array}{lll}58 & 4.3 \quad \text { nona }\end{array}$

$58 \quad 4.3 \quad$ nona

$59 \quad 4.3 \quad$ nona

66 Tabela 1 primeira onde se lê

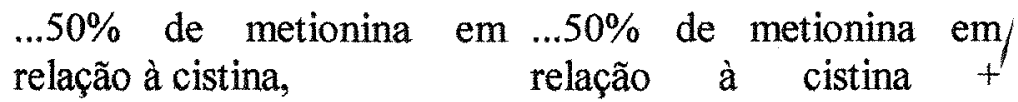
metionina

Os aminoácidos sulfurados - Os aminoácidos sulfurados lisina, treonina... mais lisina, treonina...

(d) a lisina é o aminoácido... (eliminar o período) ...(46 $\left.36^{\circ} 38^{\prime} \mathrm{S}, 23^{\circ} 15^{\prime} \mathrm{W}\right), \ldots \quad$.... $\left(23^{\circ} 15^{\prime} \mathrm{S}, 46^{\circ} 38^{\prime} \mathrm{W}\right), \ldots$ ...na represa de Santa Maria ...na represa de Barra da Serra,... ...( $\left(48^{\circ} 25^{\prime} \mathrm{S}, 22^{\circ} 35^{\prime} \mathrm{W}\right)$.

...do mesmo superscrito... ...pelo mesmo superscrito... Os aminoácidos sulfurados lisina,...

...menos abundante...

(d) a lisina é o aminoácido...

Um ingrediente de alto valor Um ingrediente de boa digestivel protéico...

...farelo de desengordurado...

** $0,03 \%$...

...em KOH

PR

Fontes protéicas...

(Tabela 5)

...o CDA deste aminoácido (eliminar o período) também foi baixo (Tabela 6).

(Tabela 5)

(Tabela 6)

Perfil de aminoácidos Perfil de aminoácidos... essenciais...

Digestível

...proteína consumida $(\mathrm{g})$ (eliminar parágrafo) 


\section{Dados Internacionais de Catalogação na Publicação (CIP) DIVISÃo DE BIBLIOTECA E DOCUMENTAÇÃO - Campus "Luiz de Queiroz"/USP}

Portz, Leandro

Utilização de diferentes fontes protéicas em dietas formuladas pelo conceito de proteína ideal para o "Black Bass" (Micropterus salmoides) / Leandro Portz. - Piracicaba, 2001.

$111 \mathrm{p}$.

Tese (doutorado) - Escola Superior de Agricultura Luiz de Queiroz, 2001.

Bibliografia.

1. Aminoácido 2. Dieta animal 3. Digestibilidade 4. Exigência nutricional 5. Percanegra I. Título

CDD 639.3758

Termitida a cópia total ou parcial deste documento, desde que citada a tonte 0 autor"

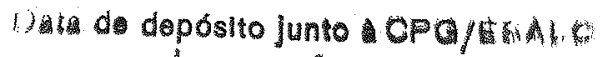

$21 / 09 / 2001$ 


\section{DEDICATÓRIA}

Dedico mais esta conquista em minha carreira profissional a minha família

Percio, Nelci, Adriano e Cristiana

pelo apoio, carinho e estímulo que nunca faltaram

e ofereço à eterna lutadora que muito fez por min

Da. Elisabeth Garlipp

("in memoriam")

"Longe daqui longe de tudo, na presença dos anjos, a ti cantarei louvores" Leandro Portz 


\section{AGRADECIMENTOS}

A Deus, por me proteger e estar ao meu lado em todos os momentos mostrando o melhor caminho a seguir;

Que estranha é a sina que cabe a nós, mortais ! Cada de um de nós está aqui para uma temporada; com que propósito, não se sabe... Os ideais que têm iluminado meu caminho, e repentinamente me têm renovado a coragem para enfrentar a vida com ânimo, são a Bondade, a Beleza e a Verdade.

Albert Einstein, The world as I see it (1931)

Aos meus pais, pelo grande exemplo de vida, educação e estímulo constantes;

À Fundação de Amparo à Pesquisa do Estado de São Paulo, pela concessão da bolsa de estudos e auxílio pesquisa financiados para realização das análises de aminoácidos;

Ao Departamento de Produção Animal e ao Curso de Pós-Graduação em Ciência Animal e Pastagens da Escola Superior de Agricultura "Luiz de Queiroz" da Universidade de São Paulo pela oportunidade de realizar este curso.

Ao Prof. Dr. José Eurico Possebon Cyrino, pela competente orientação, confiança e acima de tudo pela amizade única;

Aos Professores. Drs. José Fernando Machado Menten, Valdomiro Shigueru Miyada, Margarida Maria Barros Ferreira Lima, Luiz Edivaldo Pezzato, Luciano Verdade, Luiz Lehmann Coutinho, Dante Lanna, Wilson Mattos e Sila Carneiro da Silva, pelas sugestões e pela amizade;

Aos funcionários do Setor de Piscicultura do Departamento de Produção Animal da ESALQ, Ismael Baldessin Júnior e Sérgio Vanderlei Pena, às funcionárias da Secretaria do Departamento de Produção Animal, Cláudia Chuahy de Camargo, Creide Ely Martins, Vera Lúcia Graciano, e à Secretária do CPG Ciência Animal e Pastagens, 
Giovana Maria de Oliveira, pela amizade e apoio na condução dos trabalhos e de todos procedimentos burocráticos do doutorado;

À Nutron Alimentos, na pessoa da Enga. Agra. Srta. Alexsandra Caseiro, pelo apoio na forma da doação de ingredientes e uso dos recursos de formulação de rações;

Ao Professor Dr. Wilson Massamitu Furuya pelo valioso auxílio no levantamento bibliográfico;

À equipe da Lab Tec, nas pessoas de Lílian Fernandes Costa Priosti, Nevilson Carlos de Oliveira, Edson Brás de Brito e Rosimeire Leite dos Santos pela amizade e auxílio na condução das análises de aminoácidos.

Ao pesquisador e amigo Ricardo Cavalcanti Martino, pela fiel amizade e incentivo na realização deste trabalho;

Ao CEBTEC, na pessoa do Antônio Francisco de Campos Amaral, pela valiosa ajuda com o empréstimo do liofilizador;

Aos colegas e amigos da pós-graduação, em especial à Daniela Baconni, Ana Maria Barreto Menezes Sampaio, Luciane Conte, Geraldo Silva de Campos Almeida e Andréa Belém Costa;

Aos estagiários do Setor de Piscicultura do Departamento de Produção Animal, em especial ao André Luiz "Pesqueiro" Watanabe, pela amizade conquistada e valioso apoio prestado na execução dos experimentos;

Ao técnico agrícola André Roberto Alleoni Junior ("Limeira") pela ajuda na montagem dos aquários de digestibilidade;

À minha namorada Alesandra Bastiani dos Santos que soube me compreender, tolerar e amar;

Ao amigo e companheiro Marco Antônio Sundfeld da Gama que soube me incentivar nos momentos mais difíceis e dar todo o apoio que precisei;

Enfim, a todas as pessoas que, direta ou indiretamente, contribuíram para o sucesso deste trabalho, o meu sincero agradecimento. 


\section{SUMÁRIO}

Página

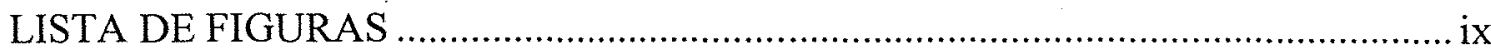

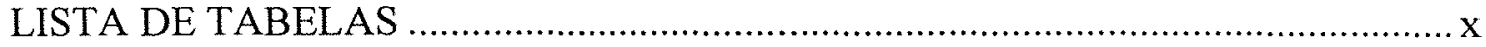

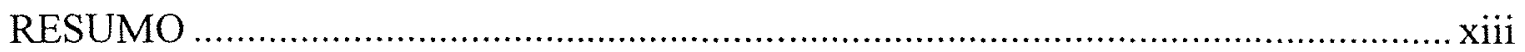

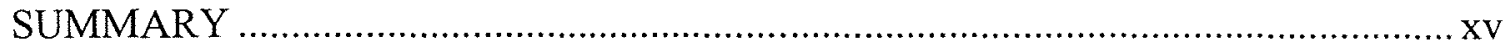

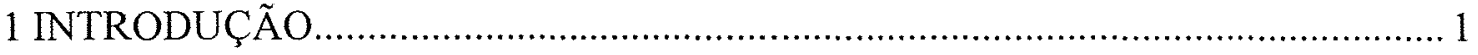

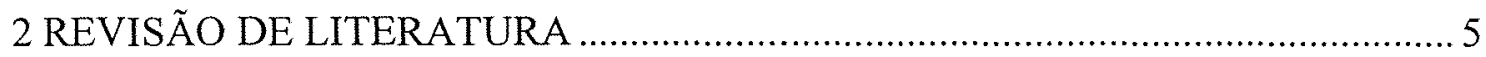

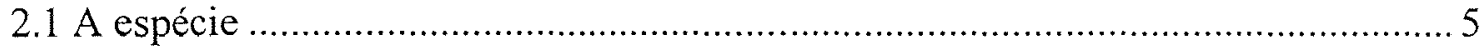

2.2 Nutrientes essenciais, com especial referência a proteína e

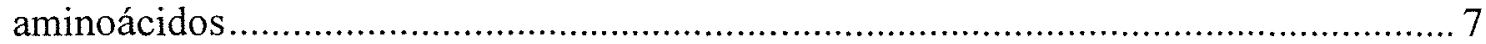

2.2.1 Exigências nutricionais dos peixes em proteína $\mathrm{e}$

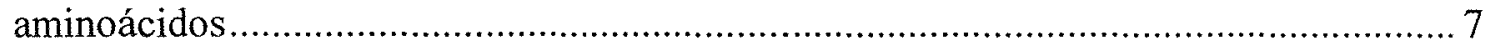

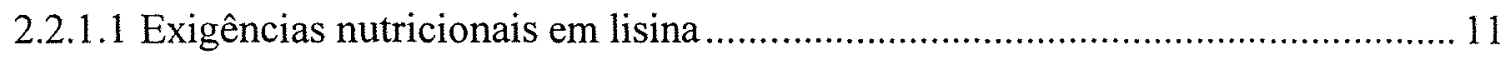

2.2.1.2 Exigências nutricionais em metionina e cistina ............................................... 12

2.2.1.3 Exigências nutricionais em triptofano ………............................................... 13

2.2.1.4 Exigências nutricionais em fenilalanina e tirosina .......................................... 13

2.2.1.5 Exigências nutricionais em arginina............................................................ 13

2.2.1.6 Interações entre leucina, isoleucina e valina ................................................... 14

2.2.2 Fatores que afetam as exigências em proteína e aminoácidos

$2.3 \mathrm{O}$ uso do conceito de proteína ideal como alternativa na determinação das exigências em aminoácidos para peixes.

2.3.1 Exigências em lisina como referência na estimativa da exigência em aminoácidos pelo conceito de proteína ideal 
2.4 Digestibilidade de aminoácidos em peixes

2.5 Uso de fontes protéicas alternativas em rações para peixes carnívoros

3 COMPARAÇÃO ENTRE A COMPOSIÇÃO DE AMINOÁCIDOS DO OVO, CARCAÇA E TECIDO MUSCULAR DO BLACK BASS (Micropterus salmoides) COMO PADRÃO PARA A DETERMINAÇÃO DAS EXIGÊNCIAS EM AMINOÁCIDOS PELO CONCEITO DE

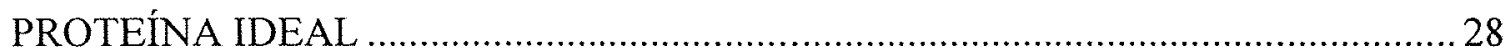

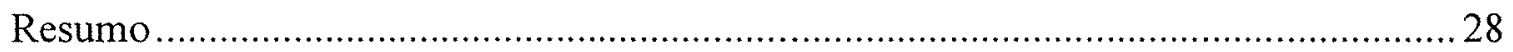

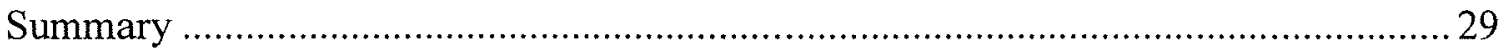

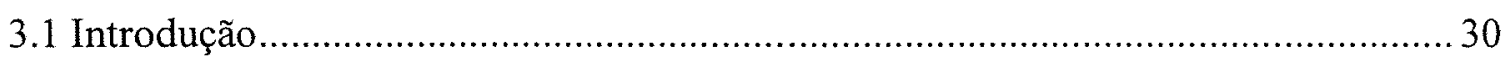

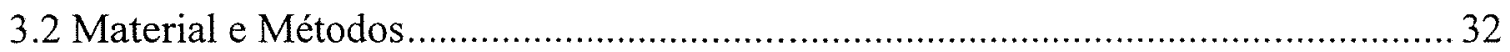

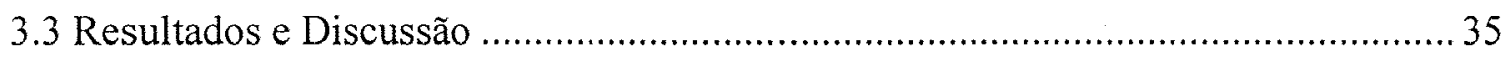

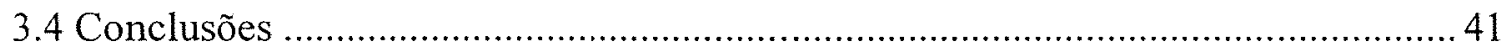

4 DIGESTIBILIDADE DE NUTRIENTES E AMINOÁCIDOS

DE DIFERENTES FONTES PROTÉICAS EM RAÇÕES

PARA O BLACK BASS Micropterus salmoides ........................................................ 42

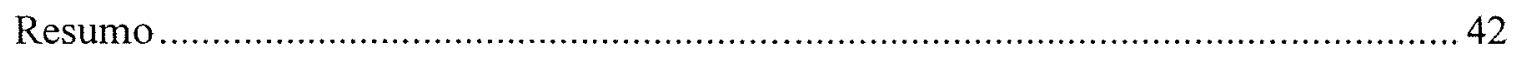

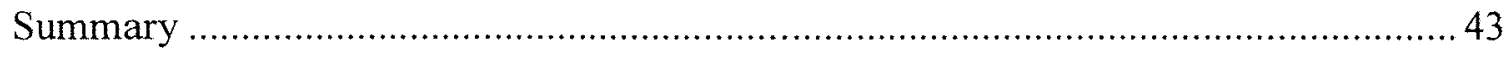

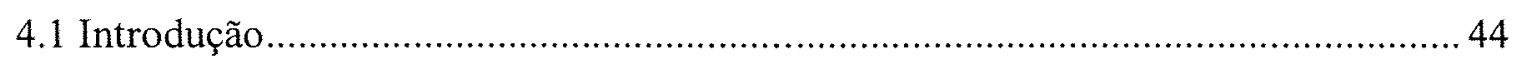

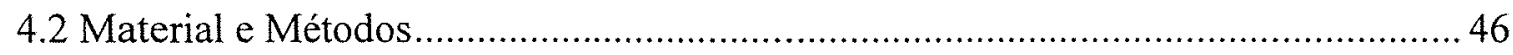

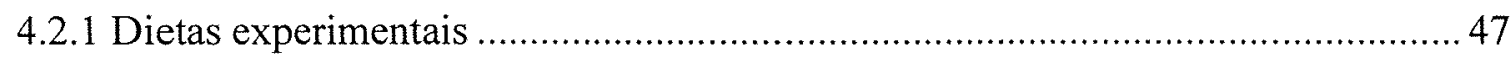

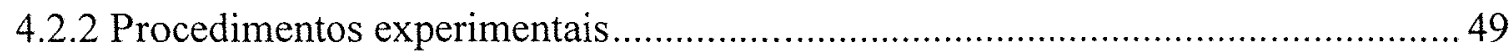

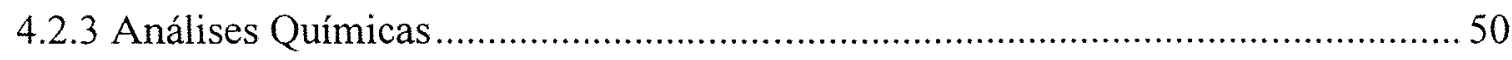

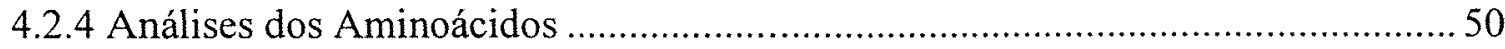

4.2.5 Determinação do coeficiente de digestibilidade aparente ....................................52

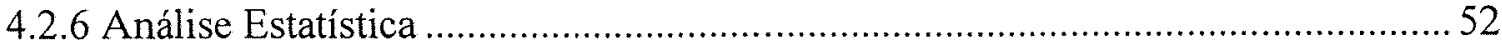

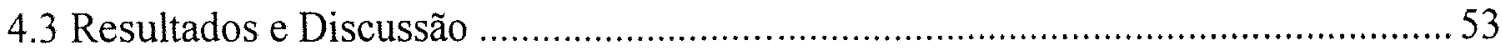

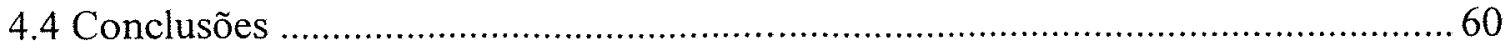


5 SUBSTITUIÇÃO DA FARINHA DE PEIXE PELA FARINHA DE VÍSCERAS EM RAÇÕES COMERCIAIS PARA O CARNÍVORO BLACK BASS Micropterus salmoides . 61

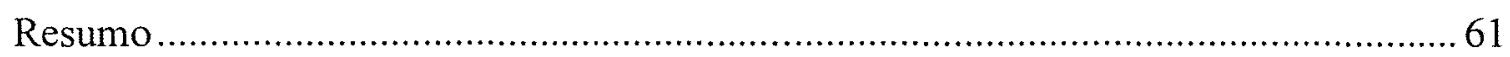

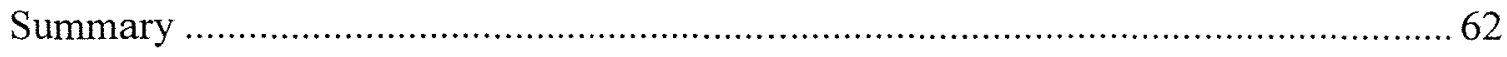

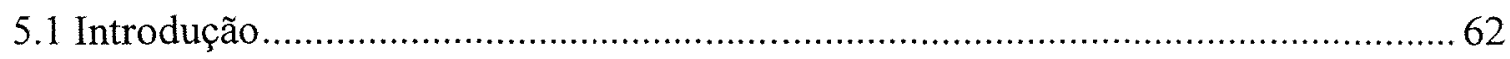

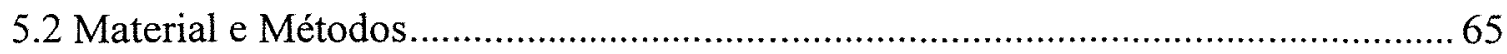

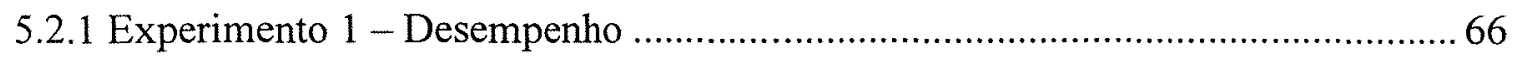

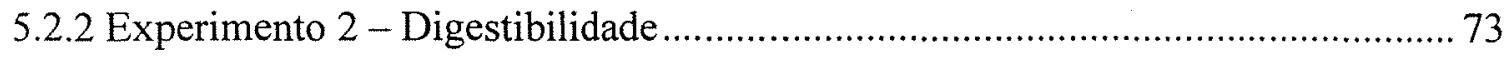

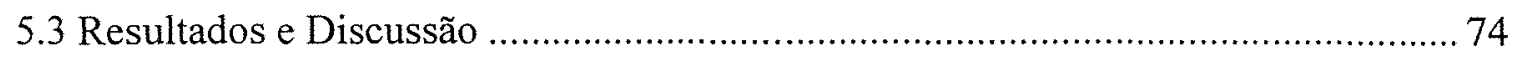

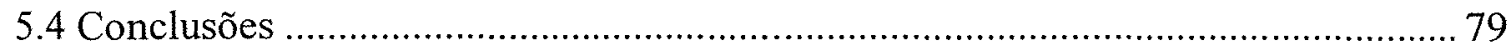

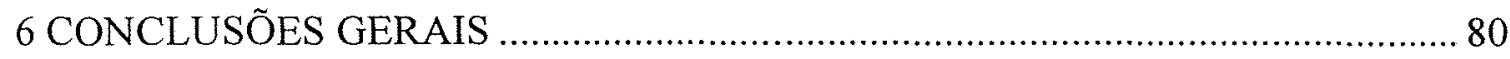

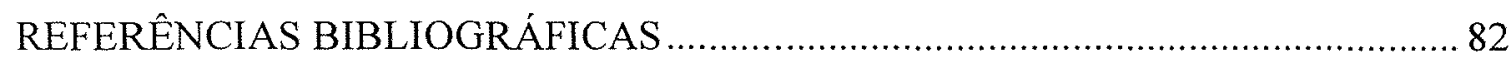




\section{LISTA DE FIGURAS}

Página

5. SUBSTITUIÇÃO DA FARINHA DE PEIXE PELA FARINHA DE VÍSCERAS EM RAÇÕES COMERCIAIS PARA O CARNÍVORO BLACK BASS Micropterus salmoides

1 Relação víscero-somática e níveis de lipídio visceral. Letras iguais não diferem significativamente $\mathrm{P}>0,05$ pelo teste Tukey (na matéria seca). 75 


\section{LISTA DE TABELAS}

Página

3 COMPARAÇÃO ENTRE A COMPOSIÇÃO DE AMINOÁCIDOS DO OVO, CARCAÇA E TECIDO MUSCULAR DO BLACK BASS (Micropterus salmoides) COMO PADRÃO PARA A DETERMINAÇÃO DAS EXIGÊNCIAS EM AMINOÁCIDOS PELO CONCEITO DE PROTEÍNA IDEAL

1 Composição centesimal de ovas, tecido muscular e carcaça do black bass, surubim e tilápia do Nilo (matéria seca - g 100 $\mathrm{g}^{-1}$ )

2. Composição de aminoácidos de ovas e tecido corporal total

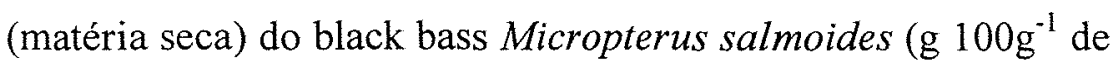
aminoácidos)

3 Composição de aminoácidos (matéria seca) do tecido muscular da tilápia do Nilo, surubim e black bass e comparação aos valores da composição de aminoácidos da carcaça do "yellowtail flounder" Pleuronectes ferruginea; "halibut" do Atlântico Hippoglossus hippoglossus; "Japanese flounder" Paralichthys olivaceus; truta arco-íris Oncorhynchus mykiss; salmão do Atlântico Salmo salar; salmão coho Oncorhynchus 
kisutch; salmão rosa Oncorhynchus gorbuscha; bagre do canal Ictalurus punctatus (g 100 ${ }^{-1}$ de aminoácidos)

4 Taxa de A/E [(aminoácido essencial / total de aminoácidos essenciais incluindo cistina e tirosina) x 1000] de espécies selecionadas.

4 DIGESTIBILIDADE DE NUTRIENTES E AMINOÁCIDOS DE DIFERENTES FONTES PROTÉICAS EM RAÇÕES PARA O BLACK BASS Micropterus salmoides

1 Análise química (matéria original) e valor econômico dos ingredientes utilizados na composição da ração referência e dietas testes (média de três repetições \pm erro padrão)

2 Composição e análise química da ração referência 48

3 Composição química (matéria original) das dietas testes (70\% da ração referência e $30 \%$ do ingrediente testado) utilizadas nos ensaios de digestibilidade

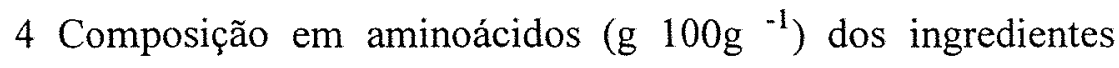
testados e da ração referência (matéria seca) 51

5 Coeficientes de digestibilidade (média de três repetições \pm erro padrão) da ração referência e ingredientes testados (valores seguidos pelo mesmo superscrito não diferem significativamente $\mathrm{P}>0,01$ ) 
6 Coeficiente de digestibilidade individual dos aminoácidos essenciais $\left(\mathrm{CDA}_{\mathrm{AAE}}\right)$, não essencial $\left(\mathrm{CDA}_{\mathrm{AANE}}\right)$, total de aminoácidos essenciais $\left(\mathrm{CDA}_{\mathrm{AAET}}\right)$; total de aminoácidos não essenciais $\left(\mathrm{CDA}_{\mathrm{AANET}}\right)$ e total de aminoácidos $\left(\mathrm{CDA}_{\mathrm{AAT}}\right)$ da ração referência e ingredientes testados (média de três repetições \pm erro padrão; valores seguidos pelo mesmo superscrito não diferem significativamente $\mathrm{P}>0,01$ )

\section{SUBSTITUIÇÃO DA FARINHA DE PEIXE PELA} FARINHA DE VÍSCERAS EM RAÇÕES COMERCIAIS PARA O CARNÍVORO BLACK BASS Micropterus salmoides

1 Perfil de aminoácidos essenciais do tecido muscular do black bass e determinação da estimativa da exigência de aminoácidos

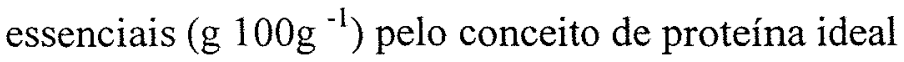

2 Ingredientes e níveis nutricionais analisados nas dietas experimentais (matéria seca)

3 Composição de aminoácidos das dietas experimentais (expressos na matéria seca como porcentagem de cada dieta).

4 Peso, ganho de peso (GP), consumo alimentar diário (CAD), conversão alimentar (CA), taxa de eficiência protéica (TEP), taxa de crescimento específico (TCE), retenção protéica (RP), retenção energética (RE), composição da carcaça' e coeficiente de digestibilidade aparente (CDA) dos nutrientes nas dietas experimentais (média \pm erro padrão de quatro repetições). Valores seguidos pelo mesmo superscrito não diferem significativamente $\mathrm{P}>0,01$ 


\section{UTILIZAÇÃO DE DIFERENTES FONTES PROTÉICAS EM DIETAS FORMULADAS PELO CONCEITO DE PROTEÍNA IDEAL PARA O "BLACK BASS" (Micropterus salmoides)}

Autor: Leandro Portz Orientador: Prof. Dr. José Eurico Possebon Cyrino

\section{RESUMO}

O desenvolvimento de rações de alto valor nutricional e economicamente viáveis depende do aprofundamento dos conhecimentos sobre as exigênçias nutricionais das espécies produzidas em sistema intensivo, objetivo deste trabalho, que visa determinar as exigências nutricionais em aminoácidos do black bass Micropterus salmoides com base no conceito da proteína ideal. Os conteúdos de nutrientes das ovas e tecido muscular do black bass foram comparados com resultados de trabalhos clássicos relacionados ao conceito de proteína ideal aplicado a diferentes espécies. O conteúdo de proteína nas ovas do black bass foi mais alto em comparação à carcaça, mas os conteúdos de lipídios das ovas e da carcaça não diferiram $(\mathrm{P}>0,01)$. As diferenças observadas entre os conteúdos de aminoácidos na carcaça da tilápia, surubim e black bass foram significativas $(\mathrm{P}<0,05)$, sendo mais elevados no black bass. $\mathrm{O}$ mesmo foi observado em relação ao teor de aminoácidos essenciais individuais e o teor de aminoácidos essenciais corporais (A/E). Os resultados indicam que os perfis de aminoácidos encontrados no black bass e surubim poderiam ser utilizados como ferramenta auxiliar no balanceamento de aminoácidos em formulações de rações para estas espécies, bem como na confirmação de valores de exigência em aminoácidos 
encontrados em estudos de desempenho. Em seguida foi avaliado o coeficiente de digestibilidade aparente da matéria seca, proteína, lipídios, energia, cálcio e fósforo, e a disponibilidade de aminoácidos, essenciais e não essenciais, de ingredientes protéicos de origem animal e vegetal utilizados em dietas práticas para peixes carnívoros. Juvenis de black bass $(8,0 \pm 0,5 \mathrm{~g} ; 10,0 \pm 0,3 \mathrm{~cm})$ confinados em gaiolas de polipropileno com uma dieta granulada ( $30 \%$ do ingrediente teste e $70 \%$ de uma ração de referência - RR), contendo $40 \% \mathrm{~PB} ; 4.741 \mathrm{kcal} / \mathrm{kg} \mathrm{EB}$ e $0,5 \%$ de $\mathrm{Cr}_{2} \mathrm{O}_{3}$. As gaiolas eram então transferidas para aquários cônicos $(200 \mathrm{~L})$ onde as fezes eram coletadas por sedimentação em recipiente refrigerado. Os ingredientes protéicos apresentaram altos coeficientes de digestibilidade aparente para proteína e lipídio. Houve diferença significativa $(\mathrm{P}<0,01)$ para todos os coeficientes de digestibilidade aparente (CDA) dos aminoácidos testados. Os resultados permitem inferir que o farelo de soja e o farelo de glúten de milho podem ser utilizados como substitutos parciais na fonte protéica de origem animal nas rações. Finalmente, com o objetivo de avaliar o efeito da substituição da farinha de peixe pela farinha de vísceras (FV) em rações para peixes carnívoros, foram formuladas, com base no conceito de proteína ideal, seis dietas comerciais isonitrogenadas $(43 \% \mathrm{~PB})$ e isocalóricas $(3.870 \mathrm{kcal} / \mathrm{kg} \mathrm{ED})$ contendo proporções crescentes de FV - 20FP:0FV; 0FP:20FV; 5FP:20FV; 10FP:15FV; 15FP:10FV; 20FP:5FV, e administradas a juvenis de black bass $(21,0 \pm 1,5 \mathrm{~g}) \mathrm{em}$ um delineamento experimental totalmente ao acaso $(n=4)$. As dietas que continham FV mostraram melhores resultados de ganho de peso e conversão alimentar $(\mathrm{P}<0,05)$, retenção protéica e energética. Com exceção do fósforo, houve diferença significativa $(\mathrm{P}<0,05)$ para os CDA da matéria seca, proteína, extrato etéreo, fibra bruta, energia e cálcio. A inclusão de $20 \%$ de $\mathrm{FV}$ em substituição à FP em rações para peixes carnívoros é tecnicamente possível e economicamente viável. 


\title{
VARYING PROTEIN SOURCES AND APPLICATION OF IDEAL PROTEIN CONCEPT IN FORMULATION OF FEEDS FOR LARGEMOUTH BASS (Micropterus salmoides)
}

\author{
Author: Leandro Portz \\ Adviser: Prof. Dr. José Eurico Possebon Cyrino
}

\section{SUMMARY}

The development of processed feeds of high nutritional value and economical feasibility depends on the in-depth knowledge about the nutritional requirements of intensively farmed fish. This work aims to determine nutritional amino acids requirements of the black bass Micropterus salmoides based in the ideal protein concept. Nutrients and amino acids contents of roe and of the carcass of different size classes of the black bass were determined and compared to results of selected, classic works related to the concept of ideal protein, dealing with different, commercially farmed fish. Protein contents in the roes of the black bass were higher in comparison to the carcass, but the contents of lipids of the roes and of the carcass did not present significant difference $(P>0,01)$. Black bass showed significantly higher muscle protein and amino acids contents in comparison to tilapia, surubim $(\mathrm{P}<0,05)$; values of the relationship between the contents of individual, essential amino acids and the total contents of essential amino (A/E) followed the same trend. Results herein presented indicate that the amino acids profile of largemouth bass and surubim could be used as complementary tool for balancing amino acids in formulated feed for these species, and in the validation of amino acids requirements determined in performance studies. Another trial was set up to evaluate apparent digestibility coefficients of dry matter, protein, lipids, energy, calcium and phosphorus, and both essential and non-essential amino acids availability of 
animal and vegetable protein sources used in practical diets of carnivorous fish. Juvenile black bass $(8,0 \pm 0,5 \mathrm{~g} ; 10,0 \pm 0,3 \mathrm{~cm})$ conditioned to accept artificial feed and stocked in plastic cages were fed with pelleted test diets $-30 \%$ of the ingredient tested mixes with $70 \%$ of a reference ration (RR), containing $40 \% \mathrm{CP}$ and $4.741 \mathrm{kcal} / \mathrm{kg} \mathrm{GE}$ and $0,5 \% \mathrm{Cr}_{2} \mathrm{O}_{3}$. Cages were transferred to cylinder, conical-bottomed aquaria $(200 \mathrm{~L})$ where the feces were collected by sedimentation in refrigerated container. Protein sources presented high apparent digestibility coefficients $(A D C)$ for protein and lipid; $\mathrm{ADC}$ of tested amino acids presented significant differences $(\mathrm{P}<0,01)$. Results allow to infer that the soybean meal and corn gluten meal can partially replace animal protein sources in carnivorous fish diets, reducing final production costs. One last assay aimed to evaluate the effects of the substitution of fish meal - FM by poultry by product meal PM in carnivorous fish feeds, formulated by the concept of ideal protein. Six commercial, iso-nitrogenous ( $43 \% \mathrm{CP})$ and iso-energetic $(3.870 \mathrm{kcal} / \mathrm{kg} \mathrm{GE})$ diets, containing increasing contents of PM - 20FM:0PM; 0FM:20PM; 5FM:20PM; 10FM:15PM; 15FM:10PM; 20FM:5PM, were fed to largemouth $(21,0 \pm 1,5 \mathrm{~g})$ in a completely randomized design $(n=4)$. Diets containing PM led to better performance and feed conversion ratio $(\mathrm{P}<0,05)$, dietetic protein and energy retention. Except for the phosphorus, differences were detected $(\mathrm{P}<0,05)$ for the ADC of dry matter, protein, lipids, crude fiber, energy and calcium. Inclusion of $20 \%$ PM in substitution to FM in feeds for carnivorous fish is technically possible and economically feasible. 


\section{INTRODUÇÃo}

$\mathrm{Na}$ última década, a produção mundial da aqüicultura aumentou de 6,7 para 20,9 milhões de toneladas métricas. Isto significa que a produção mundial da aqüicultura responde pelo equivalente a 13,7 milhões de toneladas de carne para consumo humano, o que corresponde a $6,2 \%$ da produção mundial total de 222,1 milhões de toneladas, ocupando a quarta posição, abaixo das carnes suína (37,6\%), bovina $(24,0 \%)$ e de frango $(20,9 \%)$, e acima das carnes de carneiro $(3,2 \%)$ e de outras carnes, que juntas representam 8,1\% do total (Tacon, 2001).

Com a oscilação da produção de pescado capturado, a aqüicultura deverá assumir, neste novo milênio, a responsabilidade pelo suprimento do déficit da demanda, através do aumento da utilização e da produtividade das espécies próprias para a atividade da piscicultura. Porém este crescimento deverá ser baseado nos seguintes conceitos: produção economicamente viável, segurança alimentar, sustentabilidade e o desenvolvimento sócio-econômico (Valenti, 2000).

Apesar das populações nativas de peixes apresentarem alta diversidade, a introdução ou translocação de peixes exóticos nas bacias hidrográficas brasileiras com fins de incrementar a pesca recreativa ou a piscicultura, foi prática comum no passado recente. Apenas na bacia do Rio Grande foram introduzidas e reintroduzidas várias espécies de peixes carnívoros, tanto exóticas como o "black bass" - Micropterus salmoides e a truta arco-íris - Oncorhynchus mykiss, como o nativo tucunaré - Cichla monoculum (Santos, 1994).

A criação comercial das espécies carnívoras foi impulsionada com o domínio das técnicas de propagação artificial, condicionamento e treino alimentar. Atualmente, a produção mundial de peixes carnívoros alcança duas mil toneladas/ano, e representa $6 \%$ 
do total de produtos aqüícolas produzidos no mundo (FAO, 1997). Este ramo da piscicultura exige a adoção de sistemas de criação manejados em regime intensivo, onde o manejo da nutrição desempenha o papel mais importante, exigindo sério esforço de pesquisa para geração de tecnologia adequada. As poucas pesquisas até então realizadas no país sobre o assunto tratam, em sua maioria, de adaptações de resultados de pesquisas internacionais às nossas condições.

A criação de peixes carnívoros no Brasil foi iniciada há mais de 40 anos com a introdução da truta arco-íris. Durante a década de 90, outras espécies nativas de hábito alimentar carnívoro passaram a ser exploradas, como o dourado Salminus maxillosus, o pintado ou surubim Pseudoplatystoma coruscans, o pirarucu Arapaima gigas, e o tucunaré Cichla sp., todas muito valorizadas tanto como peixes de mesa quanto peixes esportivos. Mais recentemente o "black bass" passou a merecer grande atenção dos praticantes da pesca esportiva da Região Sul do Brasil, despertando o interesse em sua criação comercial (Mouawad, 1996).

Quando comparados aos demais vertebrados na escala evolucionária, os peixes carnívoros possuem um sistema digestório simples e pouco desenvolvido. Como conseqüência, têm pouca habilidade em utilizar carboidratos como fonte energética e exigem dietas com altos níveis de proteína, que garantem não só uma alta taxa de síntese de tecido muscular, como também suprem suas necessidades energéticas (Millward, 1989). Somado a isso, as exigências nutricionais em aminoácidos dos peixes carnívoros, tanto quantitativas como qualitativas, condicionam o uso de ingredientes de origem animal na fabricação de rações para estas espécies, elevando o custo de produção.

Em sistemas de criação em regime intensivo, a densidade de peixes por unidade de área ou volume é muito alta, exigindo o uso de rações completas, de alta densidade nutricional. Existe uma preocupação dentro do contexto da aqüicultura moderna em relação aos sistemas intensivos de criação de peixes - a sustentabilidade e o impacto ambiental ou poluição causados por estes sistemas. Os resíduos de alimentos e as fezes dos peixes são uma fonte potencial considerável de poluentes orgânicos nestes sistemas (Colt \& Montgomery, 1991; Diana et al., 1997; Seim et al., 1997). 
O desenvolvimento de rações de alto valor nutricional e que garantam a economicidade das criações, depende do aprofundamento dos conhecimentos sobre as espécies produzidas, principalmente em relação ao manejo alimentar e exigências nutricionais. Estes conhecimentos vão permitir ainda a produção de rações balanceadas eficientes do ponto de vista nutricional, que permitem a adoção de estratégias de alimentação que resultem em menores níveis de resíduos nos efluentes aquaculturais.

As pesquisas sobre alimentação e nutrição de peixes carnívoros são centradas em trabalhos com os Centrarchideos, criteriosamente estudados em universidades da América do Norte e Europa. Estas espécies são consideradas modelos para aplicação e aprimoramento de novas técnicas, avaliação da qualidade nutricional de ingredientes e avaliação do potencial produtivo de espécies carnívoras. As informações sobre exigências nutricionais de Centrarchideos são de fundamental importância para uma maior precisão e eficiência na formulação de rações para peixes.

Com base no exposto, foi desenvolvido o presente trabalho, cujo objetivo foi estimar a exigência em aminoácidos para o "black bass" Micropterus salmoides, Centrarchideo norte-americano introduzido no Brasil na década de 1920, através do método de estimativa pelo conceito de proteína ideal, seguido da avaliação da digestibilidade de fontes protéicas de origem animal e vegetal pelo "black bass". Com base nos resultados dos dois capítulos anteriores, foi desenvolvido um terceiro estudo, avaliando os efeitos da substituição parcial e total da farinha de peixe no desempenho, composição corporal e digestibilidade de rações comerciais formuladas com base no conceito de proteína ideal para o "black bass".

Os resultados do presente estudo devem assumir importância significativa para o embasamento de futuras pesquisas e no desenvolvimento de rações comerciais para peixes carnívoros, trazendo inúmeros benefícios tanto para os produtores da região Sudeste, bem como de todo o país, que poderiam passar a aplicar as técnicas de adequação alimentar propostas nos estudos nutricionais desta espécie às demais espécies de peixes carnívoros, viabilizando sua criação e utilização em larga escala, tanto na indústria da produção de alimento como da pesca esportiva. O refinamento das 
estratégias de produção desta espécie de grande valor de mercado para pesca esportiva poderá abrir novas perspectivas à emergente indústria da aqüicultura brasileira. 


\section{REVISÃO DE LITERATURA}

\subsection{A espécie}

O "largemouth bass" Micropterus salmoides (Perciformes, Centrarchidae) é uma espécie originária de lagos e pequenos rios da América do Norte, podendo ser encontrada também no México e alguns países da Europa. A espécie foi introduzida no Estado de Minas Gerais em 1924 (Godoy, 1954), passando a ser conhecida como black bass e disseminando-se rapidamente pelas regiões de clima ameno do Rio de Janeiro, São Paulo e toda região sul do país, onde é manejada extensivamente como peixe esportivo e vem se constituindo em exemplo do potencial econômico da produção de espécies carnívoras.

É considerada a principal espécie da indústria de pesca esportiva nos Estados Unidos, que conta com 46 milhões de adeptos que movimentam, em média, US\$28 bilhões anualmente, ou cerca de 0,5\% do PIB daquele país (Fish and Wildlife Service, 1992, citado por Kubitza, 1995). Muitos pescadores amadores e profissionais consideram o black bass a principal espécie do mercado de peixes esportivos.

Apenas no Estado de São Paulo, onde o black bass já foi introduzido e encontra-se perfeitamente adaptado, a indústria da pesca esportiva tem movimentado, anualmente, valores brutos ao redor de R\$ 500.000.000,00 (Carvalho Filho, 1997; Scorvo Filho \& Ayrosa, 1996). Tal fato demonstra a importância de maiores estudos sobre a alimentação e nutrição de espécies esportivas, o que possibilitará sua criação em sistemas manejados intensivamente com o uso de rações completas, eliminando a necessidade da utilização de espécies forrageiras para sua alimentação, a exemplo do 
que já ocorre na América do Norte (Leyva, 1998; Lovshin \& Rushing, 1989) a partir do desenvolvimento de técnicas de treino alimentar (Snow, 1960; 1963) e seu posterior aprimoramento (Kubitza et al. 1997; Kubitza \& Lovshin 1997; Lovshin \& Rushing, 1989; Sloane, 1993).

Ensaios preliminares sobre a produção intensiva de juvenis avançados do black bass alimentados com ração comercial seca em viveiros sem renovação de água e com aeração de emergência, resultaram em produções de 2.800 a $7.200 \mathrm{~kg} / \mathrm{ha}$ (média de $4.200 \mathrm{~kg} / \mathrm{ha}$ ) em ciclos de produção de 117 a 153 dias, com valores de conversão alimentar de 0,97 a 1,14 (Kubitza \& Lovshin 1997; Kubitza et al. 1997). Estes autores citam ainda que tais resultados despertaram o interesse dos criadores em produzir juvenis avançados para programas de estocagem corretiva de represas, bem como em utilizar peixes treinados a aceitar ração comercial na produção de peixes para pesca esportiva (400 a $450 \mathrm{~g})$.

Brecka et al. (1996) realizaram experimentos com black bass, utilizando seis rações comerciais para carnívoros, e concluíram que os peixes de água quente e fria respondem de maneira diferente às rações comerciais e que as informações a respeito das exigências nutricionais do black bass são bastante limitadas. Coyle et al. (2000) afirmam que pisciculturas que criam o black bass nos Estados Unidos executam o manejo alimentar da espécie a partir de rações de salmonídeos, normalmente com mais de $40 \%$ de proteína, baseados no princípio que esta dieta estaria disponibilizando teores adequados de nutrientes e seriam mais convenientes. Contudo, as exigências específicas de nutrientes, em particular dos aminoácidos essenciais, do black bass podem ser diferenciadas. O balanço inadequado dos aminoácidos poderiam estar reduzindo o crescimento e diminuindo a conversão alimentar desta espécie quando utilizamos rações para salmonídeos. 


\subsection{Nutrientes essenciais, com especial referência a proteína e aminoácidos}

A exemplo de qualquer outro organismo, as células dos peixes contêm polipeptídeos intimamente relacionados com os processos vitais. As proteínas são os principais constituintes orgânicos do tecido dos peixes, perfazendo 65 a $75 \%$ do total de matéria seca corporal. Os peixes consomem proteínas na forma de alimento para obter aminoácidos. No processo fisiológico da digestão, a proteína é digerida ou hidrolisada liberando aminoácidos livres, os quais são absorvidos pelo trato intestinal e distribuídos pelo sangue para todos os órgãos e tecidos. Estes aminoácidos são utilizados nos tecidos para síntese de novo de proteínas.

Uma ingestão regular de proteína é exigida porque os aminoácidos são exigidos continuamente pelo organismo do peixe, tanto para formar novas proteínas crescimento e reprodução - como para repor proteínas que são degradadas no corpo do peixe - manutenção de tecidos e órgãos. Uma quantidade de proteína inadequada na dieta resulta na redução ou parada do crescimento e na perda de peso, devido à degradação de proteína dos tecidos, feita com o objetivo de manter as funções vitais (Millward, 1989). Se a quantidade de proteínas suplementada na dieta é superior às exigências do peixe, somente parte destas poderia ser utilizada para produção de novas proteínas; o excesso seria convertido em energia de armazenamento ou simplesmente eliminado (Steffens, 1989). Em relação às espécies carnívoras tropicais em geral, e às espécies brasileiras em particular, poucos são os estudos já desenvolvidos nesta área da nutrição de peixes.

\subsubsection{Exigências nutricionais dos peixes em proteína e aminoácidos}

As primeiras tentativas de determinação das exigências em proteína e aminoácidos pelos peixes foram conduzidas por J.E. Halver e seus colaboradores junto à "School of Fisheries, University of Washington, Seattle, WA, USA" no final da década de 1950 com espécies de salmão (Wilson, 1989). As avaliações das exigência em proteína e aminoácidos eram então conduzidas na forma de experimentos dose-resposta com dietas purificadas, que continham caseína, gelatina, proteína e aminoácidos 
sintéticos baseados na proporção de aminoácidos encontrada no ovo da galinha, ovo do salmão e do saco vitelínico dos alevinos (Halver, 1957; DeLong et al. 1958, 1962; Chance et al., 1964).

Geralmente a análise de dados de experimentos de exigências nutricionais em proteína e aminoácidos essenciais em experimentos de dose-resposta é conduzida através do modelo estatístico da regressão segmentada, a partir do exemplo de Zeitoun et al. (1976), que utilizaram este modelo matemático na análise e determinação da exigência de proteína dietética para a truta arco-íris Oncorhynchus mykiss a partir da análise da curva de ganho de peso da espécie. O modelo da regressão segmentada foi ainda considerado ideal na avaliação das exigências nutricionais em proteína de alevinos e juvenis de Micropterus dolomieu e Micropterus salmoides, respectivamente "smallmouth bass" e "largemouth bass" (Anderson et al., 1981), e na avaliação das exigências em aminoácidos do "stripped bass" híbrido (Griffin et al., 1992; Keembiyehetty \& Gatlin III, 1992, 1993).

Outras técnicas de determinação de exigências em aminoácidos essenciais utilizam ${ }^{14} \mathrm{C}$ como marcador isotópico (Bruckental, 1985). O marcador radioativo, acoplado a um substrato (glucose), é injetado no peixe acompanhado de um aminoácido que o peixe seria capaz de sintetizar. Todos os outros aminoácidos não são marcados e assim tenta-se determinar, por diferença, o quanto do aminoácido marcado foi incorporado ou sintetizado. Este método procura identificar apenas a essencialidade de um aminoácido, mas não o nível de exigência dietética do mesmo (Steffens, 1989).

As diferentes espécies de peixes e demais monogástricos não possuem níveis idênticos de exigência em proteína. Embora esta exigência possa variar nas mais diversas fases de vida do animal, é imprescindível que haja um perfeito equilíbrio no balanço de aminoácidos essenciais e não essenciais em todas as fases (Jobling, 1994).

Gatlin III (1999a) cita que normalmente a exigência mínima em proteína é estimada por curvas de regressão em estudos de dose-resposta mínima, também chamados de "break points" e que normalmente as exigências em proteína para carnívoros são altas - 40 a $50 \%$ da dieta. Peixes têm capacidade inata de utilizar a proteína dietética como fonte de energia (Tacon \& Cowey, 1985). A experiência mostra 
que, às vezes, as rações são formuladas com níveis protéicos insuficientes, ou com fontes de proteína de baixa qualidade e valor biológico. Neste caso, as exigências em energia normalmente são satisfeitas por fontes não protéicas, geralmente gorduras saturadas, que resultam em baixo desempenho e acúmulo excessivo de gordura visceral (Smith, 1989).

As exigências em proteína dietética de peixes carnívoros foram inicialmente investigadas em salmões Oncorhynchus tshawytscha por De Long et al. (1958). Nestes ensaios os peixes eram alimentados durante 10 semanas com dietas purificadas contendo níveis gradualmente maiores de proteína de alta qualidade. Os níveis de proteína dietética que resultavam em maior taxa de crescimento eram então considerados os níveis ótimos de exigência nutricional para os peixes. A partir do trabalho de De Long et al. (1958), vários estudos para determinação de exigências nutricionais em peixes foram conduzidos, a exemplo de Anderson et al. (1981), Brown et al. (1992), Cho (1992), Daniels \& Robinson (1986), Samantary \& Mohanty (1997) e Tidwell et al. (1996).

As exigências protéicas para peixes são normalmente expressas como porcentagem fixa da dieta ou como a relação de quilocalorias de energia dietética por gramas de proteína. As pesquisas mostram que para peixes carnívoros estas exigências nutricionais podem ser elevadas, a exemplo do observado para o linguado Pleuronectes platessa, cuja exigência nutricional em proteína bruta foi fixada em $50 \%$, ou para o "snakehead" Channa striata, cuja exigência nutricional em proteína bruta foi fixada em $52 \%$ (Wee \& Tacon, 1982).

Vários autores citam que os altos teores de proteína exigidos nas dietas dos peixes são geralmente função do seu hábito alimentar - carnívoro ou onívoro (De Silva, 1995). Entretanto, segundo Halver (1989) algumas destas exigências podem estar sendo superestimadas em função da utilização de metodologia inadequada na avaliação dos resultados dos ensaios biológicos. Pesquisas mais recentes mostram uma forte tendência na diminuição dos níveis de inclusão e uma maior preocupação com métodos alternativos na avaliação das exigências dietéticas de proteínas, principalmente no contexto do valor biológico e digestibilidade das fontes utilizadas (NRC, 1993). 
Segundo Cho (1992), a concentração ótima de proteína em rações para peixes está marcada por um delicado balanço entre energia digestível e proteína bruta. Um excesso de energia não protéica, como resultado da formulação de rações com uma relação ED/PB (energia digestível / proteína bruta) mais elástica, pode levar à inibição da ingestão voluntária antes que haja o consumo da quantidade suficiente de proteína, prejudicando a utilização de outros nutrientes: os níveis de ingestão são determinados, fundamentalmente, pela quantidade total de energia disponível na dieta (Colin et al., 1993). Uma dieta deficiente em energia em relação à proteína, resulta em redução da taxa de crescimento, uma vez que parte da proteína ingerida como alimento vai ser utilizada para manutenção das necessidades energéticas (NRC, 1993). Por outro lado, uma ingestão desproporcionalmente alta de energia leva a um maior acúmulo de gordura corporal (NRC, 1993), produzindo peixes gordurosos, característica indesejável no pescado produzido em confinamento.

Os níveis de proteína na dieta devem assegurar quantidades adequadas de aminoácidos para atender uma espécie em particular, permitindo que o organismo sintetize suas próprias proteínas para manutenção de um desenvolvimento e crescimento adequados. Além de suprir as necessidades mínimas de cada aminoácido, uma dieta fornecida a uma determinada espécie de peixe deve assegurar a manutenção de uma relação constante entre as concentrações destes aminoácidos. Excesso ou deficiência de certos aminoácidos pode causar um desequilíbrio na relação e interações entre os aminoácidos, causando sintomas metabólicos de toxicidade, antagonismo ou imbalanço, afetando a taxa de ingestão, o transporte de nutrientes, o catabolismo, a taxa de síntese e degradação de tecido muscular e formação de metabolitos tóxicos (Jaramillo et al., 1996).

Os níveis de exigência nutricional dos dez aminoácidos essenciais já estão bem definidos para as principais espécies de peixes produzidas em confinamento (Cowey, 1994). Segundo Cyrino (2000) as diversas fontes protéicas disponíveis no mercado para formulação das rações não possuem todas os mesmos valores nutricionais e níveis de aminoácidos exigidos pelo peixe, tanto quantitativa como qualitativamente. A avaliação de um ingrediente protéico deve ser feita em função da composição e digestibilidade dos 
aminoácidos nele presentes. No caso de fontes protéicas de baixo valor biológico, os níveis de proteína na forma de nitrogênio não protéico são altos. Quando ingeridos pelos peixes, estes alimentos aumentam a produção e excreção de amônia, levando a baixos índices de produtividade e piora na qualidade da água do ambiente criatório (Cho, 1990, 1992).

\subsubsection{Exigências nutricionais em lisina}

As exigências em lisina para peixes variam entre 5,0 a $6,8 \%$ da proteína da dieta, sendo os valores mais altos normalmente relacionados a peixes carnívoros. A exigência em aminoácidos para peixes deve ser determinada em termos de quantidades ótimas e ideais da dieta protéica (NRC, 1993). Segundo Coyle et al. (2000) a exigência em lisina do black bass é de $2,8 \%$ da dieta ou $6 \%$ da proteína; os autores comentam ainda que este valor é semelhante ao das exigências de outras espécies da família, como é o caso do híbrido "sunshine bass" (Morone chrysops x Morone saxatilis) (Griffin, et al., 1992; Keembiyehetty \& Gatlin III, 1993) e do "sea bass" (Dicentrarchus labrax L.) (Tibaldi \& Lanari, 1991).

Steffens (1989) descreve que níveis deficientes de lisina em dietas para truta arco-íris causam principalmente depressão na taxa de formação do colágeno. As fontes de proteína utilizadas nas rações de peixes devem conter níveis adequados de lisina para cada espécie, caso contrário, esta deverá ser suplementada na dieta. Níveis adequados de lisina melhoram consideravelmente a taxa sobrevivência e crescimento do peixe além de prevenir mortes por erosões na nadadeira caudal e deformações nas nadadeiras dorsal, peitoral e ventral (Halver, 1989).

Experimentos com truta arco-íris demonstram existir sinergismo antagônico entre os aminoácidos arginina e lisina, ou seja, um aumento do conteúdo de lisina na dieta pode levar à depressão nas concentrações de arginina no plasma sangüíneo (Jaramillo et al., 1996). Estes resultados são contestados por observações de Robinson \& Wilson (1981), Ketola (1983b) e Wilson \& Cowey (1985) que, trabalhando com bagre do canal, salmão e truta arco-íris, respectivamente, não observaram nenhum efeito 
antagônico quando as dietas destas espécies foram suplementadas com doses elevadas de lisina.

Em função do reduzido número de estudos até então realizados, muitas dúvidas persistem em relação ao metabolismo pós-absortivo de aminoácidos em peixes. Assim sendo, torna-se necessário a realização de estudos que elucidem os mecanismos e processos antagônicos entre aminoácidos no metabolismo de peixes (Nordrum et al., 2000; Rodehutscord et al., 2000).

\subsubsection{Exigências nutricionais em metionina e cistina}

Dentre estes dois aminoácidos sulfurados, a cistina é considerado não essencial, uma vez que pode ser sintetizado pelos peixes a partir de aminoácidos essenciais. Assim sendo, a metionina serve de base para quantificação das exigências nutricionais e da suplementação de cistina em rações de peixes (Halver, 1989). A metionina é um importante doador de grupamento metil e os níveis de exigência para peixes são apresentados de acordo com as concentrações dietéticas de cistina, que pode ser substituída parcialmente pela metionina (De Silva, 1995).

Baseados em estudos de crescimento e eficiência alimentar utilizando dietas purificadas contendo diferentes níveis de metionina e cistina, Moon \& Gatlin III (1991) demonstraram que alto conteúdo de cistina na dieta permite economia de aproximadamente $40 \%$ das exigências em metionina do "red drum" Sciaenops ocellatus, sem interferir significativamente com o desempenho deste peixe. O efeito economizador ou substitutivo da cistina por metionina deve ser considerado com cuidado. As fontes protéicas utilizadas nas rações devem conter um mínimo de $50 \%$ de metionina em relação à cistina, já que a metionina normalmente é o aminoácido mais limitante (Keembiyehetty \& Gatlin III, 1993).

Redução no crescimento é um dos muitos sinais de deficiência em metionina em peixes, sendo a catarata o sinal clínico mais comum (Rumsey et al., 1983). Thebault et al. (1985) citam que o excesso de metionina na dieta de peixes também é prejudicial e pode causar redução nas taxas de crescimento. Para que os peixes consigam perfeita assimilação dos aminoácidos sulfurados, é importante que sejam atendidas as exigências 
nutricionais mínimas do mineral enxofre, que deve estar presente na dieta em proporção de 1:10 com cálcio (NRC, 1993).

\subsubsection{Exigências nutricionais em triptofano}

O triptofano é o principal componente do protocolágeno e precursor do colágeno. Além de ser constituinte da proteína, o triptofano possui algumas outras funções tais como precursor da serotonina e ácido nicotínico e como um regulador do metabolismo de carboidrato (Sidransky et al., 1981). Segundo Walton et al. (1984) a maioria destas funções ainda não estão bem elucidadas em peixes. Deficiências de triptofano em peixes ocasionam hipertrofia generalizada, escoliose, deposição anormal de cálcio no rim e ossos planos; nas fase inicial de vida estas deformidades podem ser reversíveis caso a deficiência seja diagnosticada precocemente e se passe a fazer a suplementação deste aminoácido em níveis adequados (Halver, 1989).

\subsubsection{Exigências nutricionais em fenilalanina e tirosina}

A fenilalanina e a tirosina fazem parte do grupo dos aminoácidos aromáticos e seguem uma relação semelhante aos sulfurados. Para peixes, somente certa quantidade de fenilalanina pode ser suprida pela síntese a partir da tirosina. Desta forma, é muito importante determinar as quantidades adequadas dos aminoácidos aromáticos exigidas por cada espécie (Jaramillo et al., 1996). Poucos estudos demonstram o papel da tirosina como substituto de uma porção do total de aminoácidos aromáticos exigidos pelas diferentes espécies de peixe, com conseqüente economia de fenilalanina (Robinson et al., 1980). Steffens (1989) comenta ainda que para algumas espécies de peixes um excesso no conteúdo de tirosina na dieta pode causar toxicidade.

\subsubsection{Exigências nutricionais em arginina}

Uma das mais notáveis interações entre aminoácidos é o antagonismo que ocorre entre lisina e arginina (Robinson \& Wilson, 1981). A arginina tem importante função nutricional e fisiológica, considerada pelo NRC (1993) como aminoácido essencial na dieta de muitas espécies de peixes. Experimentos com leitões, ratos e 
frangos têm indicado que a sintese renal de arginina é a maior fonte endógena deste aminoácido para estes animais (Wu \& Morris, 1998). O fígado sintetiza prontamente arginina a partir da citrulina, por sua vez originada do metabolismo intestinal do glutamato. A síntese endógena via eixo intestinal-renal promove uma razoável explanação para a arginina ser considerada um aminoácido indispensável para muitas espécies de mamíferos que possuem uma taxa insuficiente de síntese (Baker, 1991).

Buentello \& Gatlin III (2000) citam que são poucos os estudos conduzidos para quantificação das exigências de arginina para peixes e que erros experimentais nestes experimentos normalmente são atribuídos aos altos conteúdos de ácido aspártico e glutamato nas dietas experimentais para ajustes dos teores de nitrogênio. Assim como o glutamato é um importante precursor para síntese endógena de arginina, este ajuste de nitrogênio nas dietas experimentais poderia afetar a determinação da real exigência de arginina da espécie de peixe estudada.

\subsubsection{Interações entre leucina, isoleucina e valina}

Estes aminoácidos de cadeia ramificada competem pela mesma via metabólica de absorção causando problemas de interação e, quando em excesso, podem ser prejudiciais ao peixe (Halver, 1989). Jaramillo (1996) cita que o antagonismo entre estes três aminoácidos foi avaliado em experimentos com salmão (Oncorhynchus tshawystscha), tendo sido observado que as exigências em isoleucina dependem da quantidade de leucina contida na dieta. Este mesmo autor observou que um excesso na concentração de isoleucina aumenta a necessidade de leucina acarretando baixo desempenho, o mesmo acontecendo quando se invertem as concentrações destes aminoácidos.

Hughes et al. (1983) observaram a ocorrência de trocas nas concentrações de aminoácidos de cadeia ramificada em experimentos com truta quando foram testadas concentrações crescentes do aminoácido valina em dietas purificadas. As concentrações de isoleucina e leucina plasmática foram mais altas nos tratamentos deficientes em valina e suas concentrações diminuíam quando os níveis de valina foram aumentados. Em experimentos com truta arco-íris foi demonstrado que embora altas concentrações 
dietéticas de leucina tem implicações tóxicas, mas não diminuem as concentrações de valina e isoleucina livre no plasma, músculo e fígado dos peixes (Cho, 1990).

\subsubsection{Fatores que afetam as exigências em proteína e aminoácidos}

Pouco se sabe sobre fatores não dietéticos que podem afetar as exigências nutricionais em proteína e aminoácidos pelos peixes confinados. Além dos fatores antinutricionais presentes em algumas fontes protéicas normalmente utilizadas nas rações - inibidores de tripsina, ácido fítico, hemaglutininas, baixos níveis de metionina do farelo de soja, por exemplo -, a idade dos peixes é um importante fator de variação das exigência nutricionais em proteína dietética e, conseqüentemente, em aminoácidos.

Geralmente as exigências em proteína diminuem à medida que o peixe cresce e envelhece. Nas fases iniciais, salmões necessitam uma dieta contendo entre 45 e $50 \%$ de proteína bruta, enquanto que no estágio juvenil esta exigência cai para $40 \%$ e na fase final do crescimento pode ser satisfeita com $35 \%$ de proteína bruta dietética (Hilton et al., 1981; NRC, 1981). O mesmo pode ser observado em relação ao bagre do canal, que na fase de pós-larva exige dietas com $40 \%$ de proteína; alevinos exigem de 30 a $35 \%$ e peixes acima de $110 \mathrm{~g}$ exigem apenas 25 a $30 \%$ de proteína bruta na dieta (Page \& Andrews, 1973; NRC, 1977, 1993).

Tilápias com menos de $1 \mathrm{~g}$ necessitam de 35 a $50 \%$ de proteína na dieta; tilápias de 1 a $5 \mathrm{~g}$, exigem de 30 a $40 \%$; de 5 a $25 \mathrm{~g}$ a exigência é de 25 a $30 \%$ e para tilápias pesando mais que $25 \mathrm{~g}$ são necessárias dietas contendo de 20 a $25 \%$ de proteína bruta (Balarin \& Haller 1982), porém estes valores ainda podem variar de acordo com a intensidade e regime de criação (Carneiro et al., 1999).

A variação de parâmetros ambientais também determina alterações nas exigências em proteína e aminoácidos pelos peixes (De Silva, 1995). DeLong et al. (1958) demonstraram que a uma temperatura de $8^{\circ} \mathrm{C}$ a exigência nutricional em proteína do salmão do Atlântico é de $40 \%$, e a $15{ }^{\circ} \mathrm{C}$ de $55 \%$. Para "stripped bass" foram determinadas exigências em proteína de $47 \%$ a $20^{\circ} \mathrm{C}$ e de $55 \%$ a $24^{\circ} \mathrm{C}$ (Millikin, 1982, 1983). Kaushik (1979) e Jaramillo (1996) citam que as exigências em arginina da truta arco-íris são menores quando a salinidade dos tanques de criação é aumentada. 
O hábito alimentar das espécies é outro fator que influencia a variação das exigências em proteína. Exceto quando criados em regime intensivo, os peixes onívoros conseguem satisfazer suas exigências nutricionais através do consumo do alimento natural, ao contrário do que é observado nas criações de peixes carnívoros, praticadas exclusivamente em regime intensivo, onde a única e exclusiva fonte de nutrientes é a ração, que deve ser completa, ou seja, suprir todas suas exigências nutricionais (Steffens, 1989). Os alimentos naturais normalmente encontrados nos ambientes de criação e explorados pelos peixes onívoros, possuem grande valor energético e alto conteúdo de proteína de excelente qualidade, o que impede a ocorrência de possíveis deficiências em aminoácidos das dietas comerciais.

O "ótimo" de proteína exigida pelos peixes em uma dieta está intimamente relacionado com o balanço energético-protéico e a composição e digestibilidade em aminoácidos, bem como com a quantidade e qualidade da fonte de energia não protéica (Halver, 1989). Em resumo, independentemente da espécie considerada, deve-se considerar que as necessidades em proteína estão influenciadas pela qualidade das fontes protéicas utilizadas, fatores ambientais, em especial a temperatura e, de maneira particular, pela idade do peixe (Tacon, 1985; Steffens, 1989; Halver, 1989).

Caso a dieta fornecida ao peixe não possua quantidades ideais de energia, este irá utilizar preferencialmente a degradação da proteína ingerida na forma de alimento para suprir suas necessidades energéticas. Segundo Portz et al. (2001) o perfeito balanceamento energético-protéico, principalmente em rações de carnívoros, é de fundamental importância. Somente assim pode-se minimizar possíveis deficiências nutricionais causadas pela deaminação de aminoácidos para produção de esqueleto carbônico e, conseqüentemente, de energia para manutenção corporal e armazenamento na forma de lipídios.

Erroneamente, em geral as características, fisiológicas, etológicas, fenotípicas e genotípicas não são levadas em consideração como um todo na formulação de rações comerciais para peixes e outros organismos aquáticos. Desta forma, há uma necessidade iminente de estudos que esclareçam possíveis dúvidas e permitam a formulação de dietas nutricionalmente mais eficientes para organismos aquáticos. 


\subsection{O uso do conceito de proteína ideal como alternativa na determinação das exigências em aminoácidos para peixes.}

Durante muitos anos as rações de peixes foram formuladas com base nas exigências em proteína bruta. Avanços no conhecimento permitiram o uso aminoácidos sintéticos nas rações a fim de suprir possíveis deficiências. Isto levou os nutricionistas a concluírem que era necessário considerar nas formulações as exigências específicas em aminoácidos considerados indispensáveis ou essenciais para um perfeito crescimento dos peixes, levando à realização de muitos estudos nos últimos 20 anos para determinação de exigência em aminoácidos de peixes (Wilson, 1989).

Entretanto este processo é extremamente caro e laborioso, já que os peixes constituem o maior grupo de vertebrados existente e possuem diferentes hábitos alimentares e exigências nutricionais específicas e variadas. Sendo assim, ainda não existem valores precisos sobre exigência em aminoácidos para muitas espécies de peixes, principalmente para as diferentes fases de vida e crescimento destas espécies. Em adição, as rações comerciais de peixes costumam apresentar um considerável desequilíbrio no balanço de aminoácidos, uma fonte extremamente cara de energia metabolizável, e uma potencial fonte de poluentes orgânicos pelo aumento da excreção direta de nitrogênio e fósforo que induzem.

Yo conceito de proteína ideal não é recente; foi descrito por Mitchell e colaboradores na década de 60 . Resumidamente, o conceito define a existência de uma combinação de aminoácidos ou proteína que é completa e prontamente disponível na digestão e metabolismo dos alimentos e que esta combinação pode ser idêntica às composição (perfil) em aminoácidos do corpo e às exigências do animal para crescimento e manutenção das atividades metabólicas (Parsons \& Baker, 1994).) Ogino (1980) considerou este conceito como sendo a ferramenta ideal na determinação das exigências em aminoácidos para carpas (Cyprinus carpio). (A vantagem do uso deste conceitos é que o mesmo pode ser adaptado facilmente a uma magnitude muito grande de situações, principalmente na formulação de dietas nutricionalmente completas, uma 
vez que as relações ideais se mantêm relativamente estáveis, independente das trocas no plano nutricional dos aminoácidos.

Vários trabalhos testaram esta mesma hipótese de correlação (Wilson \& Cowey, 1985; Cowey \& Tacon, 1983; Cowey \& Luquet, 1983a; Wood \& Soares, 1996; Akiyama et al., 1997; Fagbenro, 2000), com destaque para Wilson \& Poe (1985), que demonstraram a existência de uma relação entre os aminoácidos essenciais da carcaça ou do músculo e a exigência destes mesmos aminoácidos determinadas por estudos de crescimento. Para ser considerada ideal, uma proteína ou combinação de proteínas não deve apresentar excesso de aminoácidos. Todos os 20 aminoácidos devem estar presentes na dieta em quantidades precisas e nos níveis exigidos para uma máxima deposição protéica corporal, além de suprir os gastos com manutenção. Na elaboração deste conceito, proposto como ideal na nutrição de animais monogástricos, todos os aminoácidos indispensáveis são expressos como taxas ideais ou porcentagem de um aminoácido referência, normalmente o mais limitante. Uma vez determinado o aminoácido mais limitante, a exigência dietética para todos os aminoácidos pode ser rapidamente estimada.

Para formular dietas testes para alevinos de salmão, Arai (1981) introduziu o conceito da relação $\mathrm{A} / \mathrm{E}$, definida como a relação entre o conteúdo de cada aminoácidos essencial e o total de aminoácidos essenciais na carcaça, incluindo cistina e tirosina, multiplicado por 1.000 , e observou que peixes alimentados com as dietas formuladas com base neste conceito apresentavam maior crescimento e melhor eficiência alimentar. Uma ampla revisão sobre este conceito é apresentada na revisão de Akiyama et al. (1997). Exemplos de estudos que demonstram esta metodologia podem ser observados em Ogata et al. (1983) em experimentos com alevinos de salmão rosa; Wilson \& Poe (1985) com bagre do canal; Brown (1995) em estudos com "sunshine bass"; Small \& Soares (1998) com "stripped bass" (Morone saxatilis); e Kim \& Lall (2000) com "halibut" do Atlântico (Hippoglossus hippoglossus), linguado "yellowtail" (Pleuronectes ferruginea) e linguado japonês (Paralichthys olivaceus).

Até o momento são conhecidas as exigências quantitativas em aminoácidos essenciais apenas para um número limitado de espécies: a truta arco-íris Oncorhynchus 
mykiss (Ogino 1980), a tilápia do Nilo Oreochromis niloticus (Santiago \& Lovell 1988), a catla Catla catla (Ravi \& Devaraj 1991), a carpa comum Cyprinus carpio Nose 1979), a enguia japonesa Anguilla japonica (NRC, 1993), o bagre do canal Ictalurus punctatus (NRC, 1993), o salmão Chinook Oncorhynchus kisutch (Arai \& Ogata 1993), o "milkfish" Chanos chanos (Borlongan \& Coloso 1993) e o esturjão branco Acipenser transmontanus (Ng \& Hung 1995).

$\mathrm{O}$ conceito de proteína ideal tem sido utilizado um método alternativo para auxiliar na formulação inicial de rações de peixes, baseado na identificação da proporção de cada aminoácido nos tecidos corporais das espécies de peixes de criação (De Silva, 1995) e, com base neste conceito, os aminoácidos essenciais são estimados em relação ao aminoácido mais limitante. Alguns estudos mostram uma comparação da proporção de aminoácidos corporal dos peixes com cada aminoácido individual já determinado por outros autores em experimentos dose-resposta, que por sua vez mostram uma alta correlação perante a exigência dos aminoácidos para as espécies estudadas (Cowey \& Tacon, 1983; Wilson \& Poe, 1985). Na tentativa de determinar todos os 10 aminoácidos essenciais para muitas espécies ainda não submetidas a investigações sobre exigências nutricionais em diferentes idades de crescimento, podem ser utilizadas então, como um parâmetro alternativo bastante aproximado de estimativa das exigências em aminoácidos, as taxas de aminoácidos essenciais em relação aos aminoácidos totais do tecido muscular de peixe (Small \& Soares 1998).

Vários pesquisadores observaram aumento no crescimento e eficiência alimentar quando dietas experimentais de salmonídeos foram suplementadas com aminoácidos indispensáveis, simulando os níveis encontrados no tecido muscular, ovos ou corpo total destas espécies (Rumsey \& Ketola, 1975; Arai, 1981; Ketola, 1982; Ogata et al., 1983). Entretanto, analisando a composição de aminoácidos de ovos de várias espécies de peixes, Ketola (1982) demonstrou que, de modo geral, a composição em aminoácidos dos ovos varia bastante em comparação aos valores das concentrações de aminoácidos das composições corporais destas espécies. Este mesmo autor aponta ainda que esta diferença se dá em função das diferenças nas exigências de cada espécie para sua formação inicial. Vários autores citam que os critérios para se determinar e utilizar 
tabelas de exigências em aminoácidos para as diferentes espécies em suas diferentes fases de vida devem ser rigorosos e específicos, já que estes valores entre as espécies não podem ser intercambiáveis e correlacionados (NRC, 1993).

Comparando as exigências em aminoácidos essenciais para crescimento com valores da composição de aminoácidos do ovo, do saco vitelínico, da carcaça de alevinos e juvenis de truta arco-íris, Jobling (1994) demonstrou que os dados de composição em aminoácidos nas diversas fases de vida podem ser utilizados como uma base de informações e diretrizes na formulação de rações para uma determinada espécie em um determinado estágio de vida. Com base em observações e estudos realizados com outros animais monogástricos, Cowey \& Tacon (1983) sugeriram que as exigências em aminoácidos essenciais de um peixe podem ser, sempre, relacionadas ou governadas por um padrão de aminoácidos presentes no tecido muscular. Estes mesmos autores mostraram uma alta correlação entre os padrões de aminoácidos do tecido da carpa com os encontrados em experimentos realizados por Nose (1979), em que a exigência de cada aminoácido essencial era estabelecida através de um ensaio dose-resposta.

Wilson \& Poe (1985) observaram um coeficiente de regressão de 0,96 quando as exigências em aminoácidos essenciais para juvenis de bagre do canal Ictalurus punctatus foram correlacionadas ao padrão de aminoácidos da carcaça de peixes da mesma espécie. Um baixo coeficiente de correlação $\left(r^{2}=0,68\right)$ foi encontrado quando os autores contrastaram os valores de exigência com o padrão de aminoácidos dos ovos da espécie, mostrando que existe uma diferença entre as exigências nutricionais em aminoácidos entre as diferentes classes de idade do bagre do canal. Esta mesma hipótese foi testada por Wilson $(1981,1985)$ trabalhando com o bagre do canal, Wood \& Soares (1996) com "stripped bass" e Fagbenro (2000) com a tilápia do Nilo. Estes autores também encontraram elevada correlação entre as exigências em aminoácidos, determinadas em experimentos dose-resposta, e a composição corporal em aminoácidos das respectivas espécies em suas diferentes fases de vida. 
2.3.1 Exigências em lisina como referência na estimativa da exigência em aminoácidos pelo conceito de proteína ideal

Os aminoácidos sulfurados - lisina, treonina, triptofano, valina e arginina - são os mais importantes na nutrição dos monogástricos (Parsons \& Baker, 1994). Segundo Baker (1994a) a lisina é o aminoácido mais importante entre os aminoácidos essenciais e pode ser utilizada como aminoácido de referência devido a fatores como: (a) é um aminoácido estritamente essencial, não apresentando nenhuma via de síntese endógena; (b) ao contrário dos aminoácidos sulfurados, possui metabolismo básico e único orientado para deposição de proteína corporal; (c) as análises laboratoriais para determinação dos seus níveis nos ingredientes, rações e tecidos são bastante precisas; (d) a lisina é o aminoácido mais estudado em experimentos de dose-resposta com peixes.

Assim, uma vez estabelecida as exigências nutricionais em lisina para uma espécie em suas diversas fases de crescimento, todas as outras exigências em aminoácidos essenciais poderiam ser estimadas através do conceito de proteína ideal. A exemplo dos demais monogástricos, a lisina é o aminoácido mais limitante para peixes na fase inicial de crescimento (Robinson \& Wikson, 1981; Ketola, 1983a; Tibaldi \& Lanari, 1991; Craig \& Gatlin III, 1992; Griffin et al., 1992; Keembiyehetty \& Gatlin III, 1992; Tibaldi et al., 1994).

\subsection{Digestibilidade de aminoácidos em peixes}

Normalmente as rações para peixes possuem as mesmas características de uma ração para animais monogástricos, mas os valores de digestibilidade dos vários ingredientes utilizados na formulação de rações para os peixes são diferentes, principalmente os aminoácidos. Quando fontes de proteína de origem vegetal (e.g. glúten de milho e farelo de soja) são incluídos em dietas para peixes, seria importante considerar as diferenças em digestibilidade destas fontes protéicas para proceder às formulações das rações baseadas nas quantidades de aminoácidos digestíveis (Baker, 1991, 1994a, 1994b; Ogino, 1981). 
A digestibilidade de um nutriente pode variar consideravelmente em função do ingrediente utilizado, do nível de inclusão do nutriente na dieta, o processo de manufatura da dieta, e a interação entre seus nutrientes. Rações formuladas com precisão com base na composição centesimal dos ingredientes, podem ter até $10 \%$ de diferença na digestibilidade da energia em função da variação das fontes de lipídios, proteína e carboidratos utilizadas (Austreng et al., 1979; Morales et al., 1994; Storebakken et al., 1998). Quando o conteúdo de carboidratos não é equilibrado na composição da ração em função da digestibilidade dos ingredientes, podem ocorrer grandes perdas no aproveitamento dos nutrientes (Aksnes, 1995; Bergot \& Breque, 1983; Cho et al., 1985; De Silva \& Anderson, 1995).

Um ingrediente protéico de alta digestibilidade não necessariamente apresenta uma alta disponibilidade dos aminoácidos para os peixes (De Silva et al., 2000). Dificilmente a disponibilidade de aminoácidos nos ingredientes protéicos é avaliada em ensaios de digestibilidade para peixes. A maior parte dos pesquisadores opta apenas pela avaliação da digestibilidade da matéria seca e dos principais nutrientes, como a proteína. Inexistem na literatura trabalhos que mostrem as exigências em aminoácidos do black bass, bem como a disponibilidade dos aminoácidos das diferentes fontes protéicas utilizadas na formulação de dietas para a espécie. (Anderson et al., 1992; Burel et al., 2000; Degani et al., 1987; Furuya, 2001; Sullivan \& Reigh, 1995; Sadiku \& Jauncey 1995; Small et al., 1999; Stone et al., 2000; Storebakken et al., 2000; Mu et al., 2000; Wilson et al., 1981; Wilson \& Poe, 1985; Yehuda et al., 1997).

Os coeficientes de digestibilidade dos nutrientes das rações de peixes são baseados em medidas feitas pela coleta das fezes dos animais, o que depende fundamentalmente das condições e metodologias utilizadas na realização dos experimentos com digestibilidade. Como acima de 30\% do nitrogênio excretado pelo peixe é altamente solúvel (Lied, 1982), nenhum método de coleta de fezes de peixes está livre de erros em função das perdas por lixiviação e solubilidade de componentes, afetando assim os resultados propostos (Bureau et al., 1999; De La Noüe \& Choubert, 1986; Hajen et al., 1993a; Vens-Cappell, 1985; Windell et al., 1978). 
Vários métodos de coleta de fezes são descritos na literatura. Para alguns autores, o método que evita qualquer lixiviação na água, é feita pela retirada do peixe da água onde as amostras são coletadas diretamente da região posterior do intestino. Os métodos mais utilizados são o de dissecação (Smith \& Lovell, 1971, 1973; Austreng, 1978; Windell et al., 1978; Henken et al., 1985), compressão (Inaba et al., 1962; Nose, 1967; Austreng, 1978; Windell et al., 1978; Vens-Cappel, 1985), e sucção anal (Windell et al., 1978; Brown et al., 1985). Estes métodos exigem uma manipulação mais freqüente com peixe em questão, sendo este um fator altamente estressante podendo haver assim falhas no momento da coleta, principalmente quanto a uma quantidade representativa de material.

Os estudos sobre digestibilidade de nutrientes em peixes podem ainda ser conduzidos em câmaras metabólicas (Smith, 1971), através de peneiras acopladas em tanques (Windell et al., 1978), por pipetagem direta no fundo do tanque (Alliot et al., 1978), ou por filtragem contínua (Choubert et al., 1979, 1982). Desta forma, embora possa levar a perdas de componentes das fezes por lixiviação, a utilização do método da decantação parece ser o método menos traumático aos animais e que menos interfere na composição fecal (Cho et al., 1982). Independentemente do método selecionado e utilizado, é necessário minimizar tanto quanto possível as perdas de nutrientes por lixiviação quando se utiliza qualquer dos métodos de coleta com o peixe dentro da água (Anderson et al., 1992; Alexis et al., 1995; Allan et al., 2000; Bureau et al., 1999; Choubert et al., 1979; De Silva et al., 2000; Kabir et al., 1998; Mu et al., 2000; Spyridakis et al., 1989; Storebakken et al., 1998; Tacon \& Rodrigues, 1984; Weatherup \& McCracken, 1998).

\subsection{Uso de fontes protéicas alternativas em rações para peixes carnívoros}

Dentre os ingredientes utilizados na formulação de rações para peixes carnivoros, as fontes protéicas são consideradas as mais importantes, uma vez que estes peixes utilizam a proteína dietética não só como alimento plástico mas também como 
fonte de energia (Tacon \& Cowey, 1985). As rações representam o maior percentual no custo total da produção de peixes carnívoros, normalmente criados de forma intensiva, afetando diretamente a eficiência da produção e desenvolvimento deste ramo da piscicultura (Allan et al., 2000; Lovell, 1989a; Naylor et al., 2000).

A produção de farinha de peixe para o consumo animal emprega aproximadamente $35 \%$ do total de pescado capturado (Tacon \& Domini, 1999). Dentro de proporções aceitáveis, avicultura e suinocultura são também dependentes da farinha de peixe. Assim sendo, a produção da farinha de peixe eventualmente não será suficiente para suprir a demanda mundial. Para que haja um aumento sustentável da produção de pescado através da aqüicultura, é essencial reduzir o uso da farinha de peixe nas rações para piscicultura intensiva como um todo, na produção de espécies carnívoras em particular (Pike, 1996; Tacon, 1996; Webster et al., 1992).

As pesquisas para a escolha de possíveis substitutos para farinha de peixe são algo tendenciosas, sempre relacionadas à soja ou farelo de soja, "commodities" que cujo preço está vinculado ao dólar americano; às farinhas de sangue, carne e osso e carne, que sofrem restrições em função de problemas sanitários (e.g. mal da vaca louca) e às proteínas microbianas, que ainda apresentam problemas de disponibilidade (Webster et al., 1999; Tacon, 1994). A utilização destas fontes protéicas alternativas, de origem animal ou vegetal, ainda demandam uma avaliação mais precisa do seu valor biológico para os peixes (Boonyaratpalin et al, 1998; Gomes et al., 1995; Kikuchi, 1999; Webster et al.,1999; Webster et al, 2000). As quantidades de farinha de peixe já foram bastante reduzidas na maioria das rações de peixes carnívoros. Restam, entretanto, várias dúvidas e problemas a serem equacionados em relação balanço em aminoácidos, presença de polissacarídeos amiláceos e estruturais e à baixa digestibilidade das fontes de proteína de origem vegetal (Ozório et al., 2001).

Neste contexto, a farinha de vísceras de abatedouros avícolas aparece como uma alternativa viável para a questão da substituição da farinha de peixe por uma fonte de proteína animal de alto valor biológico, sanitariamente segura e de preço accessível (Webster et al., 1999; Lim \& Domini, 1991; Maffi, 1993). Diante da importância deste produto como possivel substituto para farinha de peixe, muitas pesquisas vem sendo 
realizadas na tentativa viabilizar a utilização eficiente deste ingrediente em dietas para peixes (Giri et al.,2000; Webter et al., 1999; Webster et al., 2000).

Avaliando rações com diferentes fontes protéicas para híbrido "sunshine bass" Morone chrysops x Morone saxatilis, Webster et al. (1999) observaram resultados de desempenho idênticos quando os peixes foram alimentados com dietas que tinham a composição protéica baseada em $32 \%$ de farelo de soja e $28 \%$ de farinha de vísceras ou $25,5 \%$ de farelo de soja e $30 \%$ de farinha de peixe; mesmo assim os autores consideraram que nem sempre a farinha de peixe pode ser substituída totalmente. Giri et al. (2000) demonstraram que o bagre africano Clarias batrachus Linn. apresenta redução no ganho de peso, conversão alimentar e retenção protéica quando o farinha de peixe é completamente substituída pela farinha de vísceras nas dietas para a espécie.

O farelo de soja é considerado uma das mais nutritivas fontes de proteína de origem vegetal. Entretanto, vários autores observaram que quanto maior a porcentagem de inclusão desta fonte protéica em rações para peixes carnívoros, piores os resultados de desempenho, conversão alimentar, taxa de eficiência protéica e retenção protéica (Webster et al., 2000, Boonyaratpalin, et al., 1998; Kaushik et al.,1995). A baixa eficiência alimentar das fontes protéicas de origem vegetal pode estar relacionada à presença de fatores antinutricionais, como inibidores de protease, carboidratos nãodigestíveis, lecitinas e fitatos, além de baixa palatabilidade, balanço inadequado de aminoácidos e menor quantidade de fósforo disponível (Furuya, 2000; Elangovan \& Shim, 2000).

Vários estudos citam a suplementação de aminoácidos sintéticos nas rações como forma de solucionar possíveis problemas na deficiência. Quando Mambrini et al. (1999) suplementaram níveis crescentes de DL-metionina em rações para truta arco-íris (Oncorhynchus mykiss) utilizando o farelo de soja como única fonte protéica, observaram uma melhora no desempenho das trutas devido ao aumento da taxa de consumo alimentar. Mambrini et al. (1999) observaram ainda que o crescimento das trutas era afetado quando a quantidade de farelo de soja na ração era superior a $50 \%$, e mesmo quando DL-metionina era adicionada à ração, o crescimento não era significativamente melhorado, o que demonstra que o uso de fontes protéicas de origem 
vegetal na nutrição dos peixes carnívoros tem como principal fator limitante os seus respectivos padrões de aminoácidos totais e digestíveis.

Webster et al. (1995) demonstraram que rações formuladas com farelo de soja em substituição à farinha de peixe, contendo $35 \%$ de proteína e suplementadas com fosfato bicálcico e L-metionina, podem ser utilizadas na alimentação de juvenis do bagre azul Ictalurus furcatus, sem que ocorram efeitos adversos no crescimento e na composição da carcaça. Entretanto, deve-se notar que a fim de atenuar possíveis problemas com a palatabilidade e equilibrar ácidos graxos essenciais nas dietas, Webster et al. (1995) equilibraram as fontes de energia das rações com óleo de fígado de peixe. Finalmente, estes autores recomendam que quando o nível protéico na ração é inferior a $30 \%$, as rações contenham um percentual mínimo de farinha de peixe, uma vez que, nestas condições, o valor biológico dos aminoácidos provenientes da soja ficaria abaixo do que é exigido pela espécie.

Em estudos com juvenis de "sea bass" alimentados com rações onde a proporção da substituição da farinha de peixe pelo farelo de soja foi de $37 \%$, não foram observadas redução no crescimento e na taxa de consumo alimentar. Quando a proporção de substituição era aumentada, foi observada uma redução no crescimento provavelmente devido a redução na taxa de consumo. Os autores do estudo, Boonyaratpalin et al, (1998), consideraram que a farinha de peixe foi melhor utilizada pelos juvenis de "sea bass" do que os produtos derivados da soja. Mais recentemente, em estudo de substituição de farinha de peixe por fontes protéicas vegetais, Burel et al. (2000) concluíram que, desde que tratadas por processo de extrusão, fontes vegetais podem substituir até $50 \%$ da farinha de peixe na dieta do tunídeo Psetta maxima sem afetar o desempenho, eficiência alimentar e qualidade da carcaça da espécie, mesmo que as dietas apresentem deficiência em lisina e metionina.

Regulamentações ambientais passam a exigir a adoção de práticas ambientalmente seguras de produção de pescado em aqüicultura. Desperdício de alimentos, nutrientes não digeridos e produtos excretados pelos peixes originam nitrogênio e fósforo, dois elementos de particular importância na saturação ambiental com matéria orgânica (Einen et al., 1995). A minimização da descarga excessiva destes 
nutrientes em sistemas intensivos de criação de peixes está diretamente relacionada ao manejo de um conjunto de parâmetros-chave relacionados à composição das dietas e taxas de alimentação dos peixes confinados.

Uma importante estratégia para o controle do efeito poluidor causado pelo desperdício de nutrientes é a redução nos teores e a substituição das fontes protéicas tradicionais de origem animal por fontes alternativas, de menor impacto ambiental. $\mathrm{O}$ conceito de formular dietas com alta densidade de nutricional e baixo efeito poluidor é utilizado com sucesso em sistemas intensivos de criação de peixes nos países desenvolvidos (Alsted, 1991; Kiaerskou, 1991; Johansen \& Wandsvik, 1991; Losordo, 1998; Meyers, 1999).

Nos países escandinavos, onde a indústria da salmonicultura intensiva alcança os maiores índices de desenvolvimento, foi observada acentuada melhora na taxa de conversão alimentar, de 4,5 para $1,2 \mathrm{~kg}$ de alimento por quilograma de salmão do Atlântico produzido em sistemas intensivos, nas últimas duas décadas (Einen, 1995), Este fato demonstra que a indústria aqüícola pode produzir de três ou até quatro vezes mais peixe com um mesmo nível de descarga de nutrientes comparado aos valores de duas décadas atrás. A taxa de conversão alimentar é um dos fatores de maior importância em sistemas de criação intensiva onde os custos de produção estão altamente atrelados a este fator. Portanto são necessárias pesquisas para o desenvolvimento de rações que sejam nutricionalmente eficientes e de alto índice de conversão alimentar, minimizando assim as descargas de matéria orgânica e nutrientes nos efluentes.

A estimativa dos coeficientes de digestibilidade dos ingredientes de uma ração traz benefícios tanto econômicos quanto ecológicos. A avaliação eficiente dos coeficientes de digestibilidade dos alimentos utilizados em piscicultura vai levar à formulação de rações mais econômicas e mais eficientes do ponto de vista do aproveitamento de nutrientes, contribuindo para que a aqüicultura se desenvolva como agroindústria economicamente viável, socialmente desejável e ambientalmente segura. 


\section{COMPARAÇÃO ENTRE A COMPOSIÇÃO DE AMINOÁCIDOS DO OVO, CARCAÇA E TECIDO MUSCULAR DO BLACK BASS (Micropterus salmoides) COMO PADRÃO PARA A DETERMINAÇÃO DAS EXIGÊNCIAS EM AMINOÁCIDOS PELO CONCEITO DE PROTEÍNA IDEAL}

\section{RESUMO}

Espécies carnívoras têm grande importância para aqüicultura mundial e demandam procedimentos de manejo alimentar específicos. Para fundamentar a estimativa das exigências em aminoácidos do black bass Micropterus salmoides com base no conceito da proteína ideal, foram determinadas a composição em nutrientes e aminoácidos das ovas e da carcaça de diferentes classes de tamanho do black bass. Os conteúdos de nutrientes do tecido muscular do black bass foram comparados com resultados de trabalhos clássicos relacionados ao conceito de proteína ideal, relativos a diferentes espécies criadas comercialmente. O conteúdo de proteína nas ovas do black bass foi mais alto em comparação à carcaça, mas os conteúdos de lipídios das ovas e da carcaça não apresentaram diferença significativa $(\mathrm{P}>0,01)$. $\mathrm{O}$ black bass apresenta teores mais altos de proteína no tecido muscular em comparação a outras espécies. As variações observadas neste estudo entre os conteúdos de aminoácidos na carcaça da tilápia, surubim e black bass foram significativas $(P<0,05)$, confirmando o que alguns autores relatam sobre variações no conteúdo de aminoácidos na carcaça entre espécies selecionadas. A mesma tendência foi observada em relação aos valores da relação entre o teor de aminoácidos essenciais corporais individuais e o teor de aminoácidos essenciais totais $(\mathrm{A} / \mathrm{E})$. Os resultados apresentados neste estudo indicam que os perfis de 
aminoácidos encontrados para o black bass e surubim poderiam ser utilizados como ferramenta auxiliar no balanceamento de aminoácidos em formulações de rações para estas espécies, bem como na confirmação de valores de exigência em aminoácidos encontrados em estudos de desempenho.

\section{SUMMARY}

Comparison of the composition of amino acids of the eggs, whole body and muscle tissue of the Black bass (Micropterus salmoides) as pattern in the determination of the requirement in amino acids for the concept of ideal protein

Carnivorous fish have fundamental importance for world aquaculture and demand specific procedures for feed management. Nutritional amino acids requirements of varying size classes of black bass Micropterus salmoides was determined using the ideal protein concept. Nutrients and amino acids contents of roe and carcass of the different size classes were determined. Nutrient contents of the muscle tissue of the black bass were compared to results of selected, classic works related to the concept of ideal protein, dealing with different, commercially farmed fish. Protein contents in the roes of the black bass were higher in comparison to the carcass, but the contents of lipids of the roes and of the carcass did not present significant difference $(\mathrm{P}<0,05)$. Black bass showed higher muscle protein contents in comparison to other species. Although some authors report variations in the contents of some amino acids in the carcass of selected species, differences observed in this study regarding carcass amino acids contents of tilapia, speckled catfish and black bass were not significant $(\mathrm{P}<0,05)$; values of the relationship between the contents of individual, essential amino acids and the total contents of essential amino $(\mathrm{A} / \mathrm{E})$ followed the same trend. Results indicate that the amino acids profile of largemouth bass and speckled catfish could be used as complementary tool for balancing amino acids in formulated feed for these species, and in the validation of amino acids requirements determined in performance studies. 


\subsection{Introdução}

O "largemouth bass" Micropterus salmoides (Perciformes, Centrarchidae) é uma espécie carnívora originária de lagos e pequenos rios da América do Norte e introduzida no Brasil em 1924 (Godoy, 1954). Conhecido popularmente como black bass, pode ser encontrado em regiões de clima mais ameno do sul e sudeste do Brasil, onde é manejada extensivamente como peixe esportivo e vem se constituindo um exemplo do potencial econômico da produção de espécies carnívoras.

As exigências em proteína de espécies carnívoras é alta, estimada entre 40 e 44 g $100 \mathrm{~g}^{-1}$ dependendo da fase de criação (Anderson et al., 1981; Portz et al., 2001). Desta forma, a suplementação protéica é um dos fatores que mais influenciam os índices de produtividade destas espécies em confinamento. A falta de estudos que determinem a exigência em proteína e aminoácidos de peixes carnívoros se estende às espécies nativas, como o pintado (Pseudoplatystoma coruscans) e o pirarucu (Arapaima gigas), espécies consideradas promissoras dentro da cadeia produtiva da piscicultura brasileira (Val et al., 2000).

Fatores endógenos e exógenos podem afetar as exigências nutricionais dos peixes. Disponibilidade de nutrientes, como energia e proteína bruta dietéticas, idade dos peixes, espécie, hábito alimentar, sexo e genética resultam em exigências variáveis de nutrientes, incluindo os aminoácidos essenciais (Jobling, 1994).

Face a dificuldade em executar inúmeros ensaios dose-resposta para quantificação de cada aminoácido essencial (Fagbenro, 2000; Kim \& Lall, 2000), nutricionistas vem desenvolvendo técnicas que utilizam o conceito de proteína ideal para solucionar problemas de determinação das exigências destes aminoácidos, considerando relações ideais de aminoácidos como base para cálculo de padrões de aminoácidos dietéticos (Arai, 1981; Ogino, 1980; Chung \& Baker, 1992; Ogata et al., 1983; Wilson \& Poe, 1985; Wang \& Fuller, 1989; NRC, 1993; Mambrini \& Kaushik, 1995).

Conceitualmente, a exigência em aminoácidos dos peixes deve ser determinada em termos de quantidades ótimas e ideais da dieta protéica (NRC, 1993). Coyle et al. (2000) mostraram que a exigência nutricional em lisina do black bass é de $2,8 \%$ da dieta, 
ou $6 \%$ da proteína, e que este valor se assemelha às exigências de outras espécies da mesma família, como o "stripped bass" híbrido Morone chrysops x Morone saxatilis (Griffin, et al., 1992; Keembiyehetty \& Gatlin III, 1993) e o "sea bass" Dicentrarchus labrax L. (Tibaldi \& Lanari, 1991).

Embora as exigências nutricionais em aminoácidos para peixes sejam conhecidas apenas para um pequeno número de espécies (NRC, 1993), entende-se que, com base em observações e estudos realizados com outros animais monogástricos, as exigências em aminoácidos essenciais dos peixes podem estar relacionadas ou serem governadas por um padrão de aminoácidos presentes nas ovas ou no tecido muscular dos peixes (Cowey \& Tacon, 1983; Tacon, 1994). Cowey \& Tacon (1983) demonstraram uma alta correlação entre os padrões de aminoácidos da carcaça da carpa com os resultados de experimentos realizados por Nose (1979), em que a exigência em cada aminoácido essencial da espécie era estabelecida em ensaios dose-resposta. Em experimentos com salmão do Atlântico e truta arco-íris, Ketola (1982) mostrou que estas espécies respondem bem a adequação na suplementação de aminoácidos na dieta simulando padrões de aminoácidos encontrado nas ovas ou na carcaça das espécies consideradas.

Vários outros autores também demonstraram esta correlação, bem como o conceito da relação entre o conteúdo de cada aminoácido essenciais e o total de aminoácidos essenciais incluindo cistina e tirosina multiplicados por mil - A/E (Arai, 1981). Uma ampla discussão sobre este conceito é apresentada por Akiyama et al. (1997). Alguns exemplos de estudos que utilizam esta metodologia podem ser observados em Ogata et al. (1983) em experimentos com alevinos de salmão rosa; Wilson \& Poe (1985) com bragre do canal; Kim \& Lall (2000) com "halibut" do Atlântico Hippoglossus hippoglossus, linguado amarelo Pleuronectes ferruginea e linguado japonês Paralichthys olivaceus; Small \& Soares (1998) com "stripped bass" (Morone saxatilis) e Brown (1995) com o "sunshine bass".

A vantagem em usar tais conceitos reside no fato que estes podem ser adaptados facilmente a um número muito grande de situações que se aplicam na formulação de dietas nutricionalmente completas, uma vez que as relações ideais se 
mantém relativamente estáveis, independente das trocas no plano nutricional dos aminoácidos (Wilson, 1981; Cowey \& Tacon, 1983; Cowey \& Luquet, 1983b; Wood \& Soares, 1996; Akiyama et al., 1997; Fagbenro, 2000). O presente estudo tem como objetivo avaliar a aparente relação existente entre os conteúdos de aminoácidos das ovas, carcaça e tecido muscular do black bass, bem como a relação $\mathrm{A} / \mathrm{E}$ do tecido muscular, para servir como subsídio em futuros estudos de exigência nutricional e formulação de dietas nutricionalmente completas para esta espécie de grande importância econômica para pesca esportiva internacional.

\subsection{Material e Métodos}

Diferentes classes de tamanhos (Tabelas 1 e 2) do carnívoro black bass (Micropterus salmoides) foram obtidos de um produtor comercial estabelecido na cidade de Piracicaba, SP, Brasil ( $\left.22^{\circ} 42^{\prime} 30^{\prime \prime} \mathrm{S}, 47^{\circ} 38^{\prime} 00^{\prime \prime} \mathrm{W}\right)$, e também capturados de uma população introduzida há 50 anos na represa Atibaia-Atibainha, da Companhia de Abastecimento de Água do Sistema Cantareira, localizada na cidade de Atibaia, SP, Brasil ( $\left.46^{\circ} 38^{\prime} \mathrm{S}, 23^{\circ} 15^{\prime} \mathrm{W}\right)$, a partir do uso de equipamentos de pesca amadora com isca artificial. Todos os peixes foram sacrificados imediatamente após a coleta por super dosagem do anestésico benzocaína e congelados imediatamente em nitrogênio líquido.

Os resultados da determinação de aminoácidos na carcaça do black bass foram comparados a determinações feitas em amostras do tecido da musculatura dorso-lombar do surubim Pseudoplatystoma fasciatum Linnaeus (1766) $(12,13 \pm 3,58 \mathrm{~kg})$ e da tilápia do Nilo Oreochromis niloticus L. (381,00 $\pm 0,85 \mathrm{~g})$, capturados de populações selvagens, respectivamente no rio Xingu $\left(6,20^{\circ} \mathrm{S} ; 52,34^{\circ} \mathrm{W}\right)$ e na represa de Santa Maria da Serra, rio Tietê $\left(48^{\circ} 25^{\prime} \mathrm{S}, 22^{\circ} 35^{\prime} \mathrm{W}\right)$.

Após evisceração dos exemplares de black bass, foram retiradas amostras da musculatura dorso-lombar e gônadas maduras das fềmeas adultas. Todas as amostras foram então moídas e imediatamente desidratadas em liofilizador a ${ }^{-50}{ }^{\circ} \mathrm{C}$. Após a secagem as amostras eram finamente moídas em gral com nitrogênio líquido, 
homogeneizadas e submetidas à analise químico-bromatológica. O mesmo procedimento amostral feito para as amostras de tecido muscular do surubin e da tilápia do Nilo.

Tabela 1. Composição centesimal de ovas, tecido muscular e carcaça do black bass,

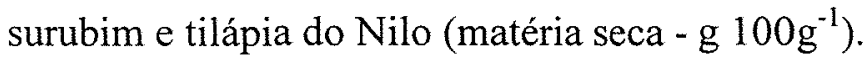

\begin{tabular}{lccccc}
\hline Black bass (g) & Proteina & Lipídio & Cinzas & Cálcio & Fósforo \\
\hline Ovas & $80,20^{\mathrm{a}} \pm 0,05^{*}$ & $16,06^{\mathrm{a}} \pm 0,01$ & - & - & - \\
$0,53 \pm 0,03^{* *}$ & $68,85^{\mathrm{b}} \pm 0,05$ & $17,11^{\mathrm{a}} \pm 0,04$ & $11,04^{\mathrm{a}} \pm 0,04$ & $3,92 \pm 0,03^{\mathrm{a}}$ & $2,55 \pm 0,01^{\mathrm{a}}$ \\
$60,96 \pm 0,87^{* *}$ & $67,17^{\mathrm{b}} \pm 0,09$ & $17,18^{\mathrm{a}} \pm 0,11$ & $12,42^{\mathrm{a}} \pm 0,02$ & $3,17 \pm 0,01^{\mathrm{b}}$ & $1,99 \pm 0,04^{\mathrm{ab}}$ \\
$278,52 \pm 2,99^{* *}$ & $69,54^{\mathrm{b}} \pm 0,11$ & $16,52^{\mathrm{a}} \pm 0,09$ & $11,26^{\mathrm{a}} \pm 0,04$ & $2,67 \pm 0,05^{\mathrm{b}}$ & $1,82 \pm 0,03^{\mathrm{b}}$ \\
$844,42 \pm 5,51^{* *}$ & $71,84^{\mathrm{b}} \pm 0,13$ & $13,88^{\mathrm{a}} \pm 0,15$ & $11,91^{\mathrm{a}} \pm 0,05$ & $2,87 \pm 0,03^{\mathrm{b}}$ & $1,86 \pm 0,03^{\mathrm{ab}}$ \\
ANOVA $(\operatorname{Pr}>F)$ & 0,0093 & 0,1347 & 0,0995 & & 0,0035 \\
Black bass*** & $87,63^{\mathrm{a}} \pm 0,05$ & $2,26^{\mathrm{b}} \pm 0,01$ & - & & 0,0007 \\
Surubin*** & $89,22^{\mathrm{a}} \pm 0,09$ & $7,70^{\mathrm{a}} \pm 0,11$ & - & - & - \\
Tilápia do Nilo*** & $69,17^{\mathrm{b}} \pm 0,11$ & $7,30^{\mathrm{a}} \pm 0,09$ & - & - & - \\
ANOVA $(\operatorname{Pr}>F)$ & 0,0101 & 0,0021 & - & - & - \\
\hline
\end{tabular}

* Média \pm coeficiente de variação de triplicatas de análises. Valores seguidos do mesmo superscrito não diferem significativamente $\mathrm{P}>0,01$.

** Amostras de carcaça

*** Amostras de tecido muscular. 
Tabela 2. Composição de aminoácidos de ovas e tecido corporal total (matéria seca) do black bass Micropterus salmoides ( $100 \mathrm{~g}^{-1}$ de aminoácidos).

\begin{tabular}{|c|c|c|c|c|c|c|c|}
\hline \multirow[b]{2}{*}{ Aminoácidos* } & \multicolumn{2}{|c|}{ Três amostragens** } & \multicolumn{3}{|c|}{ Média de três peixes (gramas) } & \multirow{2}{*}{$\begin{array}{c}\text { Erro } \\
\text { padrão }\end{array}$} & \multirow{2}{*}{$\begin{array}{c}A N O V A \\
\operatorname{Pr}>\mathrm{F}\end{array}$} \\
\hline & Ovas & 0,53 & 60,96 & 278,52 & 844,42 & & \\
\hline Arginina & $9,06 \pm 0,04^{\mathrm{ab}}$ & $10,0 \pm 0,09^{a}$ & $8,43 \pm 0,07^{b}$ & $8,50 \pm 0,01^{b}$ & $8,47 \pm 0,02^{b}$ & 0,0995 & 0,0378 \\
\hline Histidina & $2,33 \pm 0,06$ & $2,07 \pm 0,01$ & $2,07 \pm 0,07$ & $2,06 \pm 0,05$ & $2,09 \pm 0,05$ & 0,0645 & 0,7411 \\
\hline Isoleucina & $3,32 \pm 0,02^{b}$ & $3,65 \pm 0,03^{\mathrm{ab}}$ & $4,18 \pm 0,01^{\mathrm{a}}$ & $4,00 \pm 0,03^{\mathrm{ab}}$ & $4,09 \pm 0,02^{\mathrm{ab}}$ & 0,0353 & 0,0577 \\
\hline Leucina & $8,14 \pm 0,04$ & $6,75 \pm 0,08$ & $8,12 \pm 0,07$ & $8,01 \pm 0,05$ & $6,89 \pm 0,07$ & 1,1605 & 0,6553 \\
\hline Lisina & $7,39 \pm 0,01$ & $7,77 \pm 0,05$ & $7,92 \pm 0,01$ & $8,10 \pm 0,03$ & $7,91 \pm 0,03$ & 0,0763 & 0,1538 \\
\hline Metionina & $2,64 \pm 0,01$ & $2,57 \pm 0,04$ & $2,67 \pm 0,01$ & $2,59 \pm 0,04$ & $2,61 \pm 0,05$ & 0,0212 & 0,8127 \\
\hline Fenilalanina & $4,33 \pm 0,03$ & $3,94 \pm 0,04$ & $4,06 \pm 0,02$ & $3,97 \pm 0,01$ & $4,12 \pm 0,02$ & 0,0126 & 0,1496 \\
\hline Treonina & $5,00 \pm 0,02^{\mathrm{a}}$ & $4,35 \pm 0,01^{b}$ & $4,18 \pm 0,05^{b}$ & $4,40 \pm 0,02^{b}$ & $4,22 \pm 0,06^{b}$ & 0,0176 & 0,0220 \\
\hline Triptofano & $1,07 \pm 0,00$ & $0,89 \pm 0,04$ & $0,83 \pm 0,03$ & $0,89 \pm 0,02$ & $0,70 \pm 0,02$ & 0,0073 & 0,1062 \\
\hline Valina & $6,17 \pm 0,02^{a}$ & $4,21 \pm 0,04^{b}$ & $4,68 \pm 0,02^{b}$ & $4,63 \pm 0,01^{b}$ & $4,45 \pm 0,02^{b}$ & 0,0298 & 0,0026 \\
\hline Ác. Aspártico & $10,75 \pm 0,02$ & $11,99 \pm 0,01$ & $11,37 \pm 0,00$ & $11,75 \pm 0,04$ & $11,33 \pm 0,08$ & 0,1204 & 0,2670 \\
\hline Ác. Glutâmico & $12,04 \pm 0,02$ & $13,81 \pm 0,03$ & $13,42 \pm 0,01$ & $13,34 \pm 0,02$ & $14,72 \pm 0,04$ & 0,4061 & 0,2681 \\
\hline Alanina & $7,24 \pm 0,02^{\mathrm{a}}$ & $7,01 \pm 0,01^{\mathrm{ab}}$ & $6,11 \pm 0,06^{\mathrm{b}}$ & $5,97 \pm 0,04^{\mathrm{b}}$ & $6,77 \pm 0,00^{\mathrm{ab}}$ & 0,0570 & 0,0279 \\
\hline Cistina & $1,13 \pm 0,04^{a}$ & $0,62 \pm 0,04^{\mathrm{b}}$ & $0,72 \pm 0,02^{\mathrm{ab}}$ & $0,83 \pm 0,01^{\mathrm{ab}}$ & $0,77 \pm 0,04^{\mathrm{ab}}$ & 0,0108 & 0,0601 \\
\hline Glicina & $4,19 \pm 0,04^{b}$ & $7,25 \pm 0,03^{3}$ & $8,03 \pm 0,04^{a}$ & $7,76 \pm 0,05^{\mathrm{a}}$ & $8,45 \pm 0,03^{a}$ & 0,1958 & 0,0044 \\
\hline Serina & $6,09 \pm 0,05^{2}$ & $4,54 \pm 0,03^{b}$ & $3,93 \pm 0,0 \mathrm{l}^{\mathrm{c}}$ & $4,21 \pm 0,04^{b c}$ & $4,13 \pm 0,02^{b c}$ & 0,0149 & 0,0004 \\
\hline Prolina & $4,95 \pm 0,05$ & $5,34 \pm 0,01$ & $5,93 \pm 0,04$ & $5,99 \pm 0,01$ & $5,42 \pm 0,04$ & 0,0620 & 0,1027 \\
\hline Tirosina & $3,67 \pm 0,01^{\mathrm{a}}$ & $3,01 \pm 0,03^{b}$ & $3,02 \pm 0,04^{b}$ & $2,88 \pm 0,03^{\mathrm{b}}$ & $2,89 \pm 0,00^{\mathrm{b}}$ & 0,0158 & 0,0172 \\
\hline
\end{tabular}

*Média \pm coeficiente de variação de triplicatas de análises. Valores seguidos pelo mesmo superscrito não diferem significativamente $\mathrm{P}>0,05$.

**Ovos coletados de três fêmeas maduras e pós-larvas com 20 dias de vida.

As análises químico-bromatológicas das amostras foram realizadas em triplicatas com base na matéria seca e seguiram os procedimentos metodológicos da "Official Methods of Analysis of the Association of Official Analytical Chemists" (AOAC, 1984), sob padronização do Compêndio Brasileiro de Nutrição Animal (MAA, 1998). A proteína bruta foi analisada pelo método Kjeldahl $(\mathrm{N} \times 6,25)$ em um autoanalisador LECO modelo FP-428. O extrato etéreo foi determinado após extração por éter de petróleo pelo método de Soxhlet. Cálcio e fósforo foram determinados por espectrofotometria de absorção atômica (plasma) após mineralização e digestão ácida da 
amostra (Termo-Jarrel-Ash, Modelo Iris/AP). Os aminoácidos foram determinados após digestão ácida e básica e separados por cromatografia de troca iônica (HPLC).

O método de preparação das amostras para análise de aminoácidos seguiu metodologia da AOAC (2000): digestão ácida em tubos de vidro lacrados sob atmosfera de nitrogênio a $110^{\circ} \mathrm{C}$ com $\mathrm{HCl} 6 \mathrm{~N}$ por 24 horas. Os aminoácidos cistina e metionina foram determinados após oxidação com ácido perfórmico antes da hidrólise ácida como descrito por Moore (1963). Após a hidrólise as soluções eram filtradas a vácuo, diluídas a $0,25 \mathrm{M}$ com $\mathrm{HCl} 0,02 \mathrm{~N}$ para ajuste ao $\mathrm{pH} 8,5$ e filtradas em membrana Millipore $(0,45 \mu \mathrm{m})$. Para análise do aminoácido triptofano, foi realizada a hidroxilação de uma amostra com hidróxido de lítio - hidrólise alcalina. Os aminoácidos livres eram separados em um auto analisador de aminoácidos Hitachi modelo L-8500A e os resultados processados em aplicativo específico em computador acoplado. Os valores das 3 repetições das análises dos diferentes nutrientes analisados foram submetidos a análise de variância (ANOVA) depois submetidos ao teste de comparação de médias de Tukey $(\mathrm{P}>0,01$ e $\mathrm{P}>0,05)$ pelo aplicativo estatístico SAS (1985).

\subsection{Resultados e Discussão}

O conteúdo de proteína das ovas do black bass foi mais alto em comparação ao conteúdo da carcaça dos exemplares da mesma espécie (Tabela 1); as quantidades de lipídio dos ovos e carcaça e matéria mineral da carcaça não apresentaram variação significativa. Os conteúdos de cálcio e fósforo foram sempre maiores para as amostras da carcaça dos alevinos. Os conteúdos de proteína e lipídios do tecido muscular do black bass e do surubim (Tabela 1) foram maiores que da tilápia do Nilo; o surubim e a tilápia apresentaram maiores concentrações de lipídio corporal que o black bass.

A composição em aminoácidos das ovas e da carcaça de quatro classes de tamanho de black bass são apresentados na Tabela 2. A concentração de aminoácidos das ovas foi maior que as concentrações de aminoácidos corporais de quaisquer das classes de tamanho dos peixes. Entre todos os aminoácidos que apresentaram uma 
variação estatisticamente significativa $(\mathrm{P}<0,05)$, a glicina analisada no ovo do black bass foi o único aminoácido que apresentou concentrações menores que as outras classes de tamanho deste peixe. Trabalhos com outras espécies também têm demonstrado diferenças no padrão de aminoácidos dos ovos e da carcaça, sendo que as concentrações dos nutrientes nas ovas são sempre mais elevados que na carcaça (Arai, 1981; Ketola, 1982; Ogata et al., 1983; Wilson \& Poe, 1985; Jobling, 1994).

Foram comparados os conteúdos de aminoácidos do tecido muscular da tilápia, do surubim e do black bass com resultados de trabalhos clássicos conduzidos com diferentes espécies criadas comercialmente no mundo, todos relacionados ao conceito de proteína ideal (Tabela 3). As variações entre os conteúdos dos aminoácidos determinados nas análises originais dos tecidos da tilápia, do surubim e do black bass e aqueles descritos na literatura foram muito pequenas. Os conteúdos de aminoácidos do tecido muscular dos carnívoros surubim e black bass são mais semelhantes entre si do que o conteúdo de aminoácidos determinado nos tecidos da tilápia (Tabela 3). Quando foram calculados os valores das taxas A/E (Arai, 1981) dos aminoácidos essenciais corporais, a mesma tendência foi observada (Tabela 4).

O black bass apresentou as maiores taxas A/E para os aminoácidos essenciais lisina, metionina mais cistina, fenilalanina mais tirosina e treonina, e concentrações menores nas taxas dos outros aminoácidos em relação à tilápia ou ao surubim (Tabela 4). Os valores das taxas $\mathrm{A} / \mathrm{E}$ do black bass foram muito semelhantes quando comparadas com a mesma taxa para as demais espécies, tanto nas análises originais como na literatura. Segundo Wilson \& Cowey (1985), taxas A/E semelhantes entre espécies podem sugerir que exigências em aminoácidos expressas como porcentagem da proteína dietética podem ser muito similares, se não as mesmas, para as diferentes espécies.

A tilápia apresentou as maiores taxas $\mathrm{A} / \mathrm{E}$ para os aminoácidos essenciais arginina, isoleucina e leucina. Já o carnívoro surubim apresentou taxas $\mathrm{A} / \mathrm{E}$ muito semelhantes às do black bass, com exceção para o aminoácido histidina, cuja taxa foi maior (Tabela 4). 
Tabela 3. Composição de aminoácidos (matéria seca) do tecido muscular da tilápia do Nilo, surubim e black bass e comparação aos valores da composição de aminoácidos da carcaça do "yellowtail flounder" Pleuronectes ferruginea; "halibut" do Atlântico Hippoglossus hippoglossus; "Japanese flounder" Paralichthys olivaceus; truta arco-íris Oncorhynchus mykiss; salmão do Atlântico Salmo salar; salmão coho Oncorhynchus kisutch; salmão rosa Oncorhynchus gorbuscha; bagre do canal Ictalurus punctatus ( $\mathrm{g}$ $100 \mathrm{~g}^{-1}$ de aminoácidos) ${ }^{1}$.

\begin{tabular}{lcccccc}
\hline Aminoácidos & $\begin{array}{c}\text { Yellowtail } \\
\text { Flounder }^{2}\end{array}$ & Halibut $^{2}$ & $\begin{array}{c}\text { Japanese } \\
\text { Flounder }^{2}\end{array}$ & $\begin{array}{c}\text { Truta arco- } \\
\text { iris }^{3}\end{array}$ & $\begin{array}{c}\text { Salmão do } \\
\text { Atlântico }^{3}\end{array}$ & $\begin{array}{c}\text { Salmão } \\
\text { coho }^{4}\end{array}$ \\
\hline Arginina & $6,79 \pm 0,03$ & $6,85 \pm 0,02$ & $6,75 \pm 0,03$ & $6,41 \pm 0,08$ & $6,61 \pm 0,03$ & 5,99 \\
Histidina & $2,45 \pm 0,02$ & $2,88 \pm 0,02$ & $2,36 \pm 0,01$ & $2,96 \pm 0,10$ & $3,02 \pm 0,08$ & 2,99 \\
Isoleucina & $4,11 \pm 0,11$ & $4,36 \pm 0,03$ & $3,91 \pm 0,02$ & $4,34 \pm 0,08$ & $4,41 \pm 0,03$ & 3,70 \\
Leucina & $7,57 \pm 0,04$ & $7,82 \pm 0,03$ & $7,59 \pm 0,03$ & $7,59 \pm 0,03$ & $7,72 \pm 0,03$ & 7,49 \\
Lisina & $8,56 \pm 0,04$ & $8,85 \pm 0,04$ & $9,15 \pm 0,04$ & $8,49 \pm 0,06$ & $9,28 \pm 0,30$ & 8,64 \\
Metionina & $2,28 \pm 0,08$ & $2,83 \pm 0,05$ & $2,92 \pm 0,00$ & $2,88 \pm 0,50$ & $1,83 \pm 0,03$ & 3,53 \\
Fenilalanina & $3,98 \pm 0,10$ & $4,63 \pm 0,02$ & $4,55 \pm 0,02$ & $4,38 \pm 0,01$ & $4,36 \pm 0,03$ & 4,14 \\
Treonina & $4,43 \pm 0,05$ & $4,62 \pm 0,01$ & $4,49 \pm 0,02$ & $4,76 \pm 0,07$ & $4,95 \pm 0,02$ & 5,11 \\
Triptofano & $1,32 \pm 0,03$ & $1,07 \pm 0,03$ & $1,06 \pm 0,01$ & $0,93 \pm 0,01$ & $0,93 \pm 0,01$ & 1,40 \\
Valina & $5,63 \pm 0,33$ & $5,24 \pm 0,10$ & $4,57 \pm 0,01$ & $5,09 \pm 0,01$ & $5,09 \pm 0,01$ & 4,32 \\
Ác. Aspártico & $9,87 \pm 0,09$ & $10,02 \pm 0,02$ & $10,24 \pm 0,02$ & $9,94 \pm 0,13$ & $9,92 \pm 0,11$ & 9,96 \\
Ác. Glutâmico & $14,58 \pm 0,06$ & $14,42 \pm 0,03$ & $15,18 \pm 0,03$ & $14,22 \pm 0,26$ & $14,31 \pm 0,01$ & 15,25 \\
Alanina & $6,42 \pm 0,03$ & $6,00 \pm 0,02$ & $6,39 \pm 0,02$ & $6,57 \pm 0,10$ & $6,52 \pm 0,05$ & 6,08 \\
Cistina & $1,22 \pm 0,04$ & $0,87 \pm 0,02$ & $0,97 \pm 0,02$ & $0,80 \pm 0,11$ & $0,95 \pm 0,05$ & 1,23 \\
Glicina & $8,40 \pm 0,14$ & $6,65 \pm 0,06$ & $6,54 \pm 0,11$ & $7,76 \pm 0,32$ & $7,41 \pm 0,17$ & 7,31 \\
Serina & $4,62 \pm 0,07$ & $4,48 \pm 0,03$ & $4,69 \pm 0,02$ & $4,66 \pm 0,06$ & $4,61 \pm 0,03$ & 4,67 \\
Prolina & $4,58 \pm 0,08$ & $4,68 \pm 0,04$ & $4,73 \pm 0,04$ & $4,89 \pm 0,14$ & $4,64 \pm 0,01$ & 4,76 \\
Tirosina & $2,53 \pm 0,08$ & $2,82 \pm 0,03$ & $3,31 \pm 0,02$ & $3,38 \pm 0,10$ & $3,50 \pm 0,01$ & 3,44 \\
\hline
\end{tabular}


Tabela 3. Composição de aminoácidos (matéria seca) do tecido muscular da tilápia do Nilo, surubim e black bass e comparação aos valores da composição de aminoácidos da carcaça do "yellowtail flounder" Pleuronectes ferruginea; "halibut" do Atlântico Hippoglossus hippoglossus; "Japanese flounder" Paralichthys olivaceus; truta arco-íris Oncorhynchus mykiss; salmão do Atlântico Salmo salar; salmão coho Oncorhynchus kisutch; salmão rosa Oncorhynchus gorbuscha; bagre do canal Ictalurus punctatus (g $100 \mathrm{~g}^{-1}$ de aminoácidos) ${ }^{1}$.

\begin{tabular}{|c|c|c|c|c|c|c|c|}
\hline Aminoácidos & $\begin{array}{l}\text { Salmão } \\
\text { rosa }^{5}\end{array}$ & $\begin{array}{l}\text { Bagre do } \\
\text { canal }^{6}\end{array}$ & $\begin{array}{l}\text { Tilápia do } \\
\text { Nilo** }\end{array}$ & Surubim** & Back bass ** & $\begin{array}{l}\text { Erro } \\
\text { Padrão }\end{array}$ & $\begin{array}{c}A N O V A \\
\operatorname{Pr}>\mathrm{F}\end{array}$ \\
\hline Arginina & 6,23 & 6,67 & $7,98 \pm 0,06^{\mathrm{a} *}$ & $6,53 \pm 0,02^{b}$ & $6,07 \pm 0,07^{b}$ & 0,0349 & 0,0009 \\
\hline Histidina & 2,39 & 2,17 & $2,47 \pm 0,01^{\mathrm{a}}$ & $2,88 \pm 0,04^{\mathrm{ab}}$ & $2,06 \pm 0,07^{b}$ & 0,0402 & 0,0082 \\
\hline Isoleucina & 3,96 & 4,29 & $5,26 \pm 0,09^{\mathrm{a}}$ & $4,05 \pm 0,06^{b}$ & $3,47 \pm 0,01^{b}$ & 0,0530 & 0,0024 \\
\hline Leucina & 7,54 & 7,40 & $8,99 \pm 0,05^{\mathrm{a}}$ & $7,56 \pm 0,10^{b}$ & $6,94 \pm 0,07^{b}$ & 0,0657 & 0,0029 \\
\hline Lisina & 8,81 & 8,51 & $9,00 \pm 0,07^{\mathrm{a}}$ & $8,16 \pm 0,09^{b}$ & $8,18 \pm 0,01^{b}$ & 0,0374 & 0,0044 \\
\hline Metionina & 3,14 & 2,92 & $2,85 \pm 0,01$ & $2,67 \pm 0,03$ & $2,75 \pm 0,01$ & 0,0163 & 0,0298 \\
\hline Fenilalanina & 4,63 & 4,14 & $4,23 \pm 0,05^{\mathrm{a}}$ & $3,99 \pm 0,08^{\mathrm{ab}}$ & $3,70 \pm 0,02^{\mathrm{b}}$ & 0,0363 & 0,0158 \\
\hline Treonina & 4,63 & 4,41 & $5,02 \pm 0,03^{a}$ & $4,50 \pm 0,07^{b}$ & $4,18 \pm 0,05^{\mathrm{c}}$ & 0,0141 & 0,0009 \\
\hline Triptofano & 0,83 & 0,78 & $1,03 \pm 0,04$ & $0,89 \pm 0,00$ & $0,82 \pm 0,03$ & 0,0248 & 0,0551 \\
\hline Valina & 4,85 & 5,15 & $5,13 \pm 0,07^{\mathrm{a}}$ & $4,25 \pm 0,05^{b}$ & $3,83 \pm 0,02^{\mathrm{c}}$ & 0,0178 & 0,0005 \\
\hline Ác. Aspártico & 9,93 & 9,74 & $10,35 \pm 0,08^{\mathrm{a}}$ & $8,84 \pm 0,07^{b}$ & $9,51 \pm 0,00^{\mathrm{b}}$ & 0,0530 & 0,0041 \\
\hline Ác. Glutâmico & 15,39 & 14,39 & $15,02 \pm 0,04^{\mathrm{a}}$ & $13,01 \pm 0,07^{b}$ & $13,53 \pm 0,01^{\mathrm{c}}$ & 0,0212 & 0,0003 \\
\hline Alanina & 6,35 & 6,31 & $5,74 \pm 0,04^{\mathrm{a}}$ & $5,19 \pm 0,04^{b}$ & $5,61 \pm 0,06^{c}$ & 0,0081 & 0,0006 \\
\hline Cistina & 1,34 & 0,86 & $1,20 \pm 0,01^{\mathrm{a}}$ & $0,73 \pm 0,06^{b}$ & $0,89 \pm 0,02^{b}$ & 0,0187 & 0,0050 \\
\hline Glicina & 7,62 & 8,14 & $5,00 \pm 0,03^{\mathrm{a}}$ & $5,43 \pm 0,07^{\mathrm{ab}}$ & $5,76 \pm 0,04^{b}$ & 0,0363 & $0,006 \mathrm{I}$ \\
\hline Serina & 4,48 & 4,89 & $3,92 \pm 0,01^{a}$ & $3,37 \pm 0,06^{\mathrm{a}}$ & $3,86 \pm 0,01^{b}$ & 0,0286 & 0,0076 \\
\hline Prolina & 4,33 & 6,02 & $3,67 \pm 0,07$ & $3,49 \pm 0,08$ & $3,35 \pm 0,04$ & 0,0549 & 0,1142 \\
\hline Tirosina & 3,58 & 3,28 & $3,03 \pm 0,04$ & $2,88 \pm 0,11$ & $3,11 \pm 0,04$ & 0,0531 & 0,1767 \\
\hline
\end{tabular}

'Valores (média \pm erro padrão da média de tres amostras com duplicatas de análises)

${ }^{2} \mathrm{Kim} \&$ Lall $(2000)$

${ }^{3}$ Wilson \& Cowey (1985)

${ }^{4}$ Arai (1981)

${ }^{5}$ Ogata et al. (1983)

${ }^{6}$ Wilson \& Poe (1985)

*Valores seguidos pelo mesmo superscrito não diferem significativamente $\mathrm{P}>0,05$.

**Amostras de tecido muscular (média de três amostras \pm erro padrão). 
Tabela 4. Taxa de A/E [(aminoácido essencial / total de aminoácidos essenciais incluindo cistina e tirosina) $\mathrm{x} 1000$ ] de espécies selecionadas.

\begin{tabular}{|c|c|c|c|c|c|c|c|c|c|}
\hline Aminoácidos & $\begin{array}{l}\text { Yellowtail } \\
\text { flounder }^{3}\end{array}$ & Halibut $^{3}$ & $\begin{array}{l}\text { Japanese } \\
\text { flounder }\end{array}$ & $\begin{array}{c}\text { Truta } \\
\text { arco-iris }\end{array}$ & $\begin{array}{l}\text { Salmão do } \\
\text { Atlântico }^{4}\end{array}$ & $\begin{array}{c}\text { Bagre do } \\
\text { canal }^{3}\end{array}$ & $\begin{array}{c}\text { Tilápia do } \\
\text { Nilo }^{6}\end{array}$ & Surubim $^{6}$ & $\begin{array}{l}\text { Black } \\
\text { bass }{ }^{6}\end{array}$ \\
\hline Lisina & 168,3 & 167,6 & 177,2 & 163,2 & 192,5 & 183,2 & 173,2 & 179,4 & 202,6 \\
\hline Arginina & 133,4 & 129,5 & 130,7 & 123,2 & 137,1 & 143,6 & 153,5 & 143,6 & 144,5 \\
\hline Histidina & 48,2 & 54,5 & 45,7 & 58,0 & 62,7 & 46,7 & 47,5 & 63,3 & 49,0 \\
\hline Isoleucina & 80,8 & 82,5 & 75,6 & 83,4 & 91,4 & 92,3 & 101,2 & 89,1 & 82,6 \\
\hline Leucina & 148,8 & 148,0 & 147,1 & 145,9 & 160,1 & 159,3 & 173,1 & 166,2 & 165,2 \\
\hline Met + Cys & 69,0 & 70,1 & 75,3 & 70,7 & 57,7 & 81,3 & 77,9 & 74,8 & 86,7 \\
\hline $\mathrm{Phe}+\mathrm{Tyr}^{2}$ & 128,0 & 141,0 & 152,4 & 149,2 & 163,0 & 159,8 & 139,7 & 151,1 & 162,1 \\
\hline Treonina & 87,1 & 87,4 & 87,0 & 91,5 & 102,7 & 95,0 & 96,6 & 98,9 & 99,5 \\
\hline Triptofano & 26,0 & 20,2 & 20,6 & 17,9 & 19,2 & 16,8 & 19,8 & 19,6 & 19,5 \\
\hline Valina & 110,6 & 99,2 & 88,5 & 97,9 & 105,6 & 110,9 & 98,7 & 93,4 & 91,1 \\
\hline
\end{tabular}

${ }^{1}$ Metionina + cistina

${ }^{2}$ Fenilalanina + tirosina

${ }^{3} \mathrm{Kim} \&$ Lall (2000)

${ }^{4}$ Wilson \& Cowey $(1985)$

${ }^{5}$ Wilson \& Poe (1985)

${ }^{6}$ Valores calculados a partir dos valores da Tabela 3.

Vários pesquisadores têm observado aumento no crescimento e eficiência alimentar quando dietas de salmonídeos foram suplementadas com aminoácidos indispensáveis, simulando os níveis encontrados no tecido muscular, ovas ou corpo total destas espécies (Rumsey \& Ketola, 1975; Arai, 1981; Ketola, 1982; Ogata et al., 1983). Jobling (1994) comparou as exigências em aminoácidos essenciais para crescimento com valores da composição de aminoácidos das ovas, do saco vitelínico, de alevinos e de juvenis de truta arco-íris, e demonstrou que a composição em aminoácidos nas diversas fases de vida das trutas pode ser utilizada como base de informações e diretrizes na formulação de rações para a espécie em um determinado estágio de vida.

Analisando a composição de aminoácidos das ovas de várias espécies de peixes, Ketola (1982) mostrou que, de modo geral, a composição em aminoácidos dos ovos varia bastante em comparação aos conteúdos de aminoácidos dos tecidos corporais, corroborando os resultados encontrados no presente estudo com o black bass. Este 
mesmo autor sugere ainda que estas diferenças acontecem em função das diferentes exigências de cada espécie para sua formação inicial. Desta forma, sugere-se que os critérios para se determinar e utilizar tabelas de exigências em aminoácidos para as diferentes espécies em suas diferentes fases de vida devem ser rigorosos e especificos, já que as exigências não são intercambiáveis e correlacionadas entre as espécies (NRC, 1993).

Os aminoácidos sulfurados lisina, treonina, triptofano, valina e arginina, são os mais importantes na nutrição dos monogástricos (Parsons \& Baker, 1994). Pelo fato da lisina ser normalmente o aminoácido menos abundante (limitante) na maioria das fontes protéicas utilizadas na formulação de rações para monogástricos em geral, peixes em particular, Cole (1978) considera que com base no conceito de proteína ideal, as exigências nutricionais de uma determinada espécie em todos os outros aminoácidos essenciais podem ser expressas em relação às exigências de lisina.

Estas considerações são corroboradas por afirmações de Baker (1994a), para quem a lisina pode ser utilizada como aminoácido de melhor referência devido a fatores como: (a) é um aminoácido estritamente essencial, não apresentando nenhuma via de síntese endógena; (b) ao contrário dos aminoácidos sulfurados, possui metabolismo básico e único, orientado principalmente para deposição de proteína corporal; (c) as análises laboratoriais para determinação dos conteúdos de lisina nos ingredientes, rações e tecidos são bastante precisas; e (d) a lisina é o aminoácido mais estudado em experimentos de dose-resposta com peixes.

Como pode ser observado nas Tabelas 2 e 3 , a lisina foi o aminoácido essencial encontrado em maior abundância na carcaça e no tecido muscular do black bass, da tilápia e do surubim, enquanto o triptofano apresentou as menores concentrações. Desta forma, atenção redobrada deve ser dada às concentrações costumeiramente reduzidas destes aminoácidos nos ingredientes utilizados em dietas para peixes (Kim \& Lall, 2000).

Wilson \& Poe (1985) compararam as taxas A/E calculadas através de conteúdos de aminoácidos determinados na análise da carcaça e em estudos de dose-resposta com bagre do canal e concluíram que existia uma alta correlação entre estas taxas. Este fato 
suporta a idéia de que seria possível formular dietas para o black bass utilizando o padrão das taxas de $\mathrm{A} / \mathrm{E}$ da carcaça (Tabela 4), simulando um balanço ótimo de aminoácidos essenciais necessário para o máximo de desempenho deste peixe.

Através de uma análise diagramática de dissimilaridade entre a taxa $\mathrm{A} / \mathrm{E}$ calculada com dados de estudos dose-resposta e em análise do perfil de aminoácidos da carcaça em diferentes espécies de peixes, Akiyama et al. (1997) deduziram que quando a taxa $\mathrm{A} / \mathrm{E}$ era calculada através das exigências em aminoácidos essenciais estimados em estudos feitos pelo conceito de proteína ideal, as exigências em aminoácidos de famílias e espécies distintas filogeneticamente eram semelhantes, ao contrário do que era observado quando estes mesmos valores eram comparados pela determinação da exigência de aminoácidos através de estudos dose-resposta.

\subsection{Conclusões}

O perfil de aminoácidos no tecido muscular e na carcaça do black bass é, aparentemente, um índice muito melhor do que o padrão das ovas para determinação das exigências nutricionais em aminoácidos pela espécie. As pequenas diferenças encontradas na composição de alguns aminoácidos da carcaça do black bass com peso vivo variando entre 0,53 e $844,0 \mathrm{~g}$, pode servir como uma indicação de que as exigências em aminoácidos da espécie, quando expressas como porcentagem da proteína dietética, diferem com o aumento do tamanho do peixe. As relações entre aminoácidos apresentadas neste estudo indicam que as exigências em aminoácidos do black bass e do surubim, espécies ictiófagas, não apresentam maiores variações, ao contrário da tilápia, espécie herbivora; e estas poderiam ser utilizadas como uma ferramenta de auxílio no ajuste do balanceamento de aminoácidos em formulações de rações para estas espécies. 


\section{DIGESTIBILIDADE DE NUTRIENTES E AMINOÁCIDOS DE DIFERENTES FONTES PROTÉICAS EM RAÇÕES PARA O BLACK BASS Micropterus salmoides}

\section{RESUMO}

A digestibilidade de nutrientes em peixes varia com o hábito alimentar da espécie e com a origem da fonte dos nutrientes da dieta. O objetivo deste trabalho foi avaliar o coeficiente de digestibilidade aparente da matéria seca, proteína, lipídios, energia, cálcio e fósforo, e a disponibilidade de aminoácidos, essenciais e não essenciais, de ingredientes protéicos de origem animal e vegetal utilizados em dietas práticas de peixes carnívoros. Juvenis de black bass Micropterus salmoides $(8,0 \pm 0,5 \mathrm{~g} ; 10,0 \pm 0,3$ $\mathrm{cm})$ condicionados a aceitar alimento artificial e confinados em gaiolas de polipropileno, eram alimentados no período diurno com uma dieta teste granulada, que consistia de 30

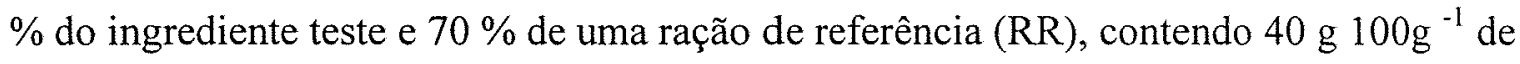
proteína bruta e $19,85 \mathrm{~kJ} \mathrm{~g}^{-1}$ de energia bruta e $0,5 \%$ do indicador óxido de cromio. No período noturno as gaiolas eram transferidas para aquários cilindro-cônicos de $200 \mathrm{~L}$ onde as fezes eram coletadas por sedimentação em recipiente refrigerado. Os ingredientes protéicos testados apresentaram altos coeficientes de digestibilidade aparente para proteína e lipídio. Houve diferença significativa $(\mathrm{P}<0,01)$ para todos coeficientes de digestibilidade dos aminoácidos testados. A presença dos ingredientes de origem vegetal não influenciou significativamente o coeficiente de digestibilidade das dietas. Os resultados apresentados permitem inferir que o farelo de soja e o farelo de glúten de milho podem ser utilizados como substitutos parciais na fonte protéica de 
origem animal nas rações, reduzindo o custo final de produção das dietas para peixes carnívoros.

\section{SUMMARY}

Digestibility of nutrients and amino acids of different protein sources in rations for the black bass Micropterus salmoides

Digestibility of nutrients in fish varies with the species feeding habits and with the origin of the nutrient source of the diet. This study aims to evaluate apparent digestibility coefficients of dry matter, protein, lipids, energy, calcium and phosphorus, and both essential and non-essential amino acids availability of animal and vegetable protein sources used in practical diets of carnivorous fish. Juvenile black bass Micropterus salmoides $(8,0 \pm 0,5 \mathrm{~g} ; 10,0 \pm 0,3 \mathrm{~cm})$ conditioned to accept artificial feed and stocked in plastic cages were fed in the daytime period with pelleted test diets $30 \%$ of the ingredient tested mixes with $70 \%$ of a reference ration (RR), containing $40 \mathrm{~g}$ $100 \mathrm{~g}^{-1}$ of crude protein and $19,85 \mathrm{~kJ} \mathrm{~g}^{-1}$ gross energy and $0,5 \%$ of cromic oxide. At night cages were transferred to cylinder, conical-bottomed aquaria $(200 \mathrm{~L})$ where the feces were collected by sedimentation in refrigerated container. Protein sources presented high apparent digestibility coefficients for protein and lipid; apparent digestibility coefficients of tested amino acids of varying protein sources presented significant differences $(\mathrm{P}<0,01)$. Vegetable nutrient sources did not influence significantly apparent digestibility coefficients of diets. Results allow to infer that the soybean meal and corn gluten meal can partially replace animal protein sources in carnivorous fish diets, reducing final production costs. 


\subsection{Introdução}

O "largemouth bass" Micropterus salmoides (Perciformes, Centrarchidae) é uma espécie originária de lagos e pequenos rios da América do Norte, encontrada também no México e alguns países da Europa e introduzida no Brasil através do Estado de Minas Gerais em 1924 (Godoy, 1954). Disseminou-se rapidamente pelas regiões de clima ameno do Rio de Janeiro, São Paulo e toda região sul do país, passando a ser conhecida como black bass. A espécie é manejada extensivamente como peixe esportivo e vem se constituindo em exemplo do potencial econômico da produção de espécies carnívoras.

O black bass é uma espécie carnívora, com exigência nutricional em proteína

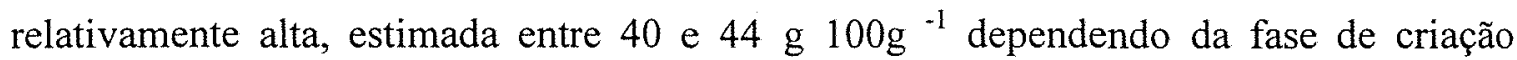
(Anderson et al., 1981; Portz et al., 2001). A proteína é o macronutriente de maior custo em rações de peixes, mas devido ao seu alto valor biológico e palatabilidade (Contreras, 1999) continua sendo utilizada como a principal fonte protéica nas formulações de rações para peixes carnívoros.

O aumento na demanda de farinha de peixe de qualidade no Brasil pela ascendente indústria de ração de peixe nacional, levantam a necessidade de definição de fontes alternativas de proteína para rações. Existe ainda um aumento constante no preço de mercado da farinha de peixe de qualidade atrelado à sazonalidade da oferta deste ingrediente (Galleguillos \& Romo, 1992). Em adição, o surgimento da encefalomielite espongiforme bovina, conhecida como "doença da vaca louca", está causando uma drástica diminuição da utilização de fontes protéicas como a farinha de carnes em diversos países, aumentando a demanda por farinha de peixe e outras fontes de proteína de origem animal (Lusas, 1999).

A emissão de poluentes orgânicos ao meio ambiente é, por vezes, associada à intensificação da aqüicultura que utiliza grandes quantidades de fontes protéicas nas rações de peixes carnívoros (Mayers, 1999). A seleção de ingredientes protéicos de alta digestibilidade torna-se cada vez mais importante para o controle e diminuição deste efeito poluidor. $\mathrm{O}$ conceito de formular dietas com alta densidade de nutrientes e baixo 
efeito poluidor já é utilizado com sucesso em sistemas intensivos de criação de peixes na Europa (Alsted, 1991; Johnsen \& Wandsvik, 1991; Kiaerskou, 1991).

Para solução ou minimização destes problemas são apresentadas então as alternativas de desenvolvimento de rações com alta energia para espécies carnívoras criadas intensivamente (Cho \& Kaushik, 1990; Johnsen \& Wandsvik 1991; Kiaerskou, 1991) e a substituição da farinha de peixe, em vários níveis, por fontes protéicas alternativas de origem vegetal e animal (Allan et al., 2000; Alvarez et al., 1999; Belal \& Assem, 1995; Carter \& Hauler, 2000; Elangovan \& Shim, 2000; Mambrini et al., 1999; Stone et al., 2000; Tacon 1990; Tacon \& De Silva, 1997; Webster et al., 1995; Webster et al., 2000).

Os ingredientes utilizados em rações comerciais para peixes carnívoros na indústria da alimentação animal brasileira ainda não foram suficientemente bem avaliados em relação à digestibilidade de nutrientes. Em geral, as formulações de rações comerciais são baseados em dados da literatura internacional para espécies de clima temperado e em ensaios de digestibilidade in vitro utilizando pepsina para digestão (Akeson \& Stahman, 1964). A maior exatidão nas formulações das rações comerciais para peixes depende da determinação dos coeficientes de digestibilidade dos diferentes alimentos utilizados nas rações bem como do refinamento dos conhecimentos sobre as exigências nutricionais das espécies (Cho et al., 1985; De Silva \& Anderson, 1995).

Um ingrediente de alto valor digestível protéico não necessariamente apresenta uma disponibilidade dos aminoácidos essenciais equivalente e em quantidades suficientes para o peixe (De Silva et al., 2000). Dificilmente a disponibilidade de aminoácidos nos ingredientes protéicos tem sido avaliada em ensaios de digestibilidade para peixes (Anderson et al., 1992; Furuya, 2000; Mu et al., 2000; Sadiku \& Jauncey 1995; Small et al., 1999; Stone et al., 2000; Storebakken et al., 2000). A maior parte das pesquisas opta apenas pela avaliação da digestibilidade da matéria seca e dos principais nutrientes, como a proteína (Burel et al., 2000; Degani et al., 1997; Sullivan \& Reigh, 1995; Wilson \& Poe, 1985; Yehuda et al., 1997).

Com base no exposto, os objetivos do presente estudo foram determinar os coeficientes de digestibilidade aparente da matéria seca, proteína, lipídios, energia, 
cálcio e fósforo, aminoácidos essenciais e não essenciais e aminoácidos totais de quatro fontes protéicas tradicionalmente utilizadas na indústria de alimentação de peixes: duas de origem animal - farinha de peixe e farinha de vísceras - e duas de origem vegetal farelo de soja desengordurado e farelo de glúten de milho ou protenose.

\subsection{Material e Métodos}

O experimento foi conduzido no Laboratório de Nutrição de Peixes do Departamento de Produção Animal da Escola Superior de Agricultura Luiz de Queiroz, Campus Luiz de Queiroz da Universidade de São Paulo, em Piracicaba, SP (22 $42^{\circ} 30^{\prime \prime S}$; $47^{\circ} 38^{\prime} 00^{\prime \prime} \mathrm{W}$; altitude $546 \mathrm{~m}$ ). O laboratório conta com sistema fechado de recirculação de água com temperatura controlada por bomba de troca de calor $\left(26 \pm 0,5{ }^{\circ} \mathrm{C}\right)$, é iluminado por 8 lâmpadas de halogênio de $370 \mathrm{~W}$, controladas por temporizador, mantendo um fotoperíodo de 14L:10E, segundo recomendações de Heinen (1998). O monitoramento dos parâmetros de qualidade da água foi feito duas vezes ao dia através de equipamentos eletrônicos: medidor de pH marca Hanna HI 1280; medidor de oxigênio marca Mettler modelo MO 128; amônia e nitrito através do kit de análise de água modelo $\mathrm{HACH} / \mathrm{FF}-2$.

A escolha dos ingredientes protéicos de origem animal - farinha de peixe (FP) e farinha de vísceras (FV) - e vegetal - farelo de soja (FS) e farelo de glúten (FG) - foi baseada na disponibilidade, preço, composição química e resultados apresentados por pesquisas já conduzidas com peixes carnívoros com estes produtos (Tabela 1) (De Silva et al., 2000; Small et al., 1999; Sullivan \& Reigh, 1995; Mu et al., 2000). A determinação dos coeficientes de digestibilidade aparente (CDA) foi feita pelo método indireto utilizando o marcador inerte óxido de cromio $\left(\mathrm{Cr}_{2} \mathrm{O}_{3}\right)$, recomendado para estudos de digestibilidade com peixes (Brisson, 1956; Furukawa \& Tsukahara, 1966; Gaylord \& Gatlin III, 1996; Lied, 1982; Shiau \& Chem, 1993; Shiau \& Lin, 1993; Shiau $\&$ Liang, 1995; Shiau \& Shy, 1998). A estimativa da digestibilidade dos ingredientes foi baseada nos estudos e procedimentos descritos por De Silva \& Anderson (1995), em que 
uma dieta referência é utilizada em conjunto com dietas testes formuladas com base na substituição de proporções entre a dieta referência e os ingredientes.

Tabela 1. Análise química (matéria original) e valor econômico dos ingredientes utilizados na composição da ração referência e dietas testes (media de três repetições \pm erro padrão).

\begin{tabular}{|c|c|c|c|c|}
\hline \multirow{2}{*}{ Nutriente } & \multicolumn{4}{|c|}{ Ingredientes $\left({\left.\mathrm{g} 100 \mathrm{~g}^{-1}\right)}^{-1}\right.$} \\
\hline & $\begin{array}{c}\text { Farinha de } \\
\text { peixe }\end{array}$ & $\begin{array}{c}\text { Farinha de } \\
\text { vísceras }\end{array}$ & Farelo de soja & $\begin{array}{l}\text { Farelo de } \\
\text { glúten }\end{array}$ \\
\hline Matéria seca & $89,10 \pm 0,85$ & $88,88 \pm 1,12$ & $89,26 \pm 1,41$ & $89,51 \pm 2,03$ \\
\hline Proteína bruta & $67,47 \pm 1,01$ & $57,83 \pm 0,90$ & $46,90 \pm 0,49$ & $60,79 \pm 0,87$ \\
\hline Extrato etéreo & $8,48 \pm 3,89$ & $15,67 \pm 2,85$ & $1,30 \pm 3,21$ & $8,16 \pm 3,25$ \\
\hline Cálcio & $3,02 \pm 0,12$ & $3,40 \pm 0,53$ & $0,25 \pm 0,14$ & $0,07 \pm 0,29$ \\
\hline Fósforo & $2,18 \pm 1,74$ & $2,16 \pm 0,39$ & $0,55 \pm 0,11$ & $0,26 \pm 0,52$ \\
\hline Energia bruta $\left(\mathrm{kJ} \mathrm{g}^{-1}\right)$ & $19,98 \pm 1,51$ & $19,94 \pm 1,77$ & $19,88 \pm 2,41$ & $20,44 \pm 3,03$ \\
\hline Valor (U\$/tonelada) & 475,00 & 204,17 & 158,33 & 245,83 \\
\hline
\end{tabular}

\subsubsection{Dietas experimentais}

Foi adquirida uma ração referência (RR) comercial, extrusada (extrusora Wenger Mod. X-165, rosca única), formulada para peixes carnívoros (Tabela 2). As dietas-teste consistiam da mistura de $30 \%$ do ingrediente testado e $70 \%$ da RR, como recomendado por Hajen et al. (1993) e McGoogan \& Reigh (1996). A composição química da RR e dietas-teste estão apresentadas nas Tabelas 2 e 3.

Para obtenção das dietas-teste a RR era feita a trituração em granulometria inferior a $1,5 \mathrm{~mm}$. e adicionada de $0,5 \%$ do indicador inerte $\mathrm{Cr}_{2} \mathrm{O}_{3}$. A mistura era 
umedecida com $20 \%$ de água destilada e compactada em grânulos de $4,0 \mathrm{~mm}$ e seca em estufa com ventilação forçada a $45^{\circ} \mathrm{C}$ por 24 horas. Após secagem as rações eram armazenadas em recipientes plásticos sob refrigeração $\left(4^{\circ} \mathrm{C}\right)$ até sua utilização.

Tabela 2. Composição e análise química da ração referência.

\begin{tabular}{|c|c|c|}
\hline Ingrediente & $\begin{array}{l}\text { Ração Referência } \\
\qquad\left(\mathrm{g} 100 \mathrm{~g}^{-1}\right)\end{array}$ & $\begin{array}{c}\text { Valor } \\
\text { (U\$/ton.) }\end{array}$ \\
\hline Farinha de peixe chilena ("arenque") & 5,00 & 475,00 \\
\hline Farinha de vísceras de frango & 15,00 & 204,17 \\
\hline Farinha de pena hidrolizada & 7,00 & 154,17 \\
\hline Farelo de soja & 35,00 & 158,33 \\
\hline Farelo de glúten de milho & 2,53 & 245,83 \\
\hline Farinha de trigo & 9,53 & 87,50 \\
\hline Farinha de sorgo & 18,13 & 83,33 \\
\hline Óleo $^{1}$ & 6,23 & 625,00 \\
\hline Mistura mineral e vitamínica ${ }^{2}$ & 1,30 & $5.000,00$ \\
\hline \multicolumn{3}{|l|}{ Análise Química (matéria original) } \\
\hline Matéria seca & 93,66 & \\
\hline Proteína bruta & 41,85 & \\
\hline Lipídio & 10,36 & \\
\hline Cálcio & 0,93 & \\
\hline Fósforo & 0,90 & \\
\hline Energia $\left(\mathrm{kJ} \mathrm{g}^{-1}\right)$ & 19,85 & \\
\hline
\end{tabular}

'2/3 de óleo de soja e 1/3 de óleo de salmão do Atlântico;

${ }^{2}$ Suplementação/kg de ração: $30 \mathrm{mg}$ de $\mathrm{Mn} ; 120,0 \mathrm{mg}$ de $\mathrm{Fe} ; 150,0 \mathrm{mg}$ de $\mathrm{Zn} ; 17,0 \mathrm{mg}$ de $\mathrm{Cu} ; 0,2 \mathrm{mg}$ de $\mathrm{Co} ; 0,9 \mathrm{mg}$ de $\mathrm{I} ; 8.700$ UI de vitamina $A ; 20,0 \mathrm{mg}$ de $B_{6} ; 4.300$ UI de $D_{3} ; 170$ UI de vitamina $E ; 30,0$ $\mathrm{mcg}$ de $\mathrm{B}_{12} ; 10,0 \mathrm{mg}$ de $\mathrm{B}_{1} ; 20,0 \mathrm{mg}$ de $\mathrm{B}_{2} ; 4,3 \mathrm{mg}$ de $\mathrm{K} ; 2,0 \mathrm{mg}$ de Ácido fólico; $1,0 \mathrm{mg}$ de Biotina; 0,6 $\mathrm{mg}$ de Selênio; $40,0 \mathrm{mg}$ de Ácido pantotênico; $40,0 \mathrm{mg}$ de niacina; $1.500,00 \mathrm{mg}$ de Colina; $100,0 \mathrm{mg}$ de Inositol; $300,0 \mathrm{mg}$ de vitamina $\mathrm{C}$ (estabilizada com radicais fosfato). 
Tabela 3. Composição química (matéria original) das dietas testes $(70 \%$ da ração referência e $30 \%$ do ingrediente testado) utilizadas nos ensaios de digestibilidade.

\begin{tabular}{|c|c|c|c|c|}
\hline \multirow{2}{*}{ Nutrientes } & \multicolumn{4}{|c|}{ 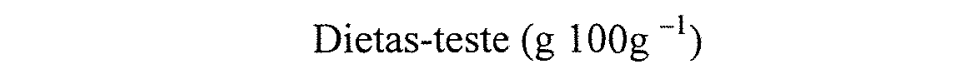 } \\
\hline & FP & FV & $\mathrm{FS}^{* *}$ & $\mathrm{FG}$ \\
\hline Proteína Bruta & $49,54 \pm 2,22^{*}$ & $46,64 \pm 1,77$ & $43,37 \pm 1,81$ & $47,53 \pm 0,90$ \\
\hline Extrato etéreo & $9,80 \pm 2,20$ & $11,95 \pm 3,60$ & $7,64 \pm 3,41$ & $9,70 \pm 1,39$ \\
\hline Cálcio & $1,56 \pm 0,10$ & $1,67 \pm 1,00$ & $0,73 \pm 0,21$ & $0,67 \pm 1,11$ \\
\hline Fósforo & $1,28 \pm 0,47$ & $1,28 \pm 0,03$ & $0,80 \pm 0,29$ & $0,71 \pm 0,71$ \\
\hline Energia bruta $\left(\mathrm{kJ} \mathrm{g}^{-1}\right)$ & $19,88 \pm 3,01$ & $19,87 \pm 3,50$ & $19,85 \pm 2,91$ & $20,02 \pm 1,99$ \\
\hline
\end{tabular}

$\mathrm{FP}=$ farinha de peixe; $\mathrm{FV}=$ farinha de vísceras; $\mathrm{FS}=$ farelo de soja $; \mathrm{FG}=$ farelo de glúten de milho

* desvio padrão da média

** $0,03 \%$ de atividade ureática e $80,93 \%$ de solubilidade em $\mathrm{KOH}$

\subsubsection{Procedimentos experimentais}

Os experimentos foram conduzidos em quatro aquários de digestibilidade cilindro-cônicos de fibra de vidro com capacidade de $200 \mathrm{~L}$, equipados com aerador, troca de água controlada e recipiente coletor de fezes refrigerado. Cada dieta-teste era administradas a 400 juvenis de black bass $(8,0 \pm 0,5 \mathrm{~g}$ e 10,0 $\pm 0,3 \mathrm{~cm})$, condicionados a aceitar alimento inerte e distribuídos em 4 gaiolas plásticas $(80 \mathrm{~L})$, rígidas, de fundo vazado, mantidas em tanques de polipropileno $(1.000 \mathrm{~L})$. Os peixes foram aclimatizados e submetidos a simulações de coleta de fezes durante 20 dias recebendo a $R R$ até que o volume de fezes fosse adequado para realização das análises e pudessem ser considerados uma repetição.

Completada a aclimatização, os peixes foram alimentados ad libitum em 5 refeições diárias entre $8 \mathrm{~h} 00 \mathrm{~m}$ e $18 \mathrm{~h} 00 \mathrm{~m}$ com as dietas-teste. Os peixes eram então anestesiados (benzocaína; $0,5 \mathrm{~g} 100 \mathrm{~L}^{-1}$ ) e as gaiolas transferidas para os aquários de digestibilidade permanecendo por um período de 10 horas, onde as fezes eram coletadas por sedimentação em recipiente refrigerado, centrifugadas $\left(4{ }^{\circ} \mathrm{C}\right)$, liofilizadas $\left(-55^{\circ} \mathrm{C}\right)$ e armazenadas em super congelador $\left(-10^{\circ} \mathrm{C}\right)$. 


\subsubsection{Análises Químicas}

As análises químico-bromatológicas das rações, ingredientes (Tabelas 1, 2 e 3) e fezes foram realizadas em triplicatas com base na matéria seca de acordo com procedimentos da "Official Methods of Analysis of the Association of Official Analytical Chemists" (AOAC, 1984), sob padronização do Compêndio Brasileiro de Nutrição Animal (MAA, 1998). A proteína bruta foi analisada pelo método Kjeldahl (N $x$ 6,25) em um auto-analisador LECO modelo FP-428. O extrato etéreo foi determinado após extração por éter de petróleo pelo método de Soxhlet. Cálcio, fósforo e o cromio foram determinados por espectrofotometria de absorção atômica (plasma) após mineralização e digestão ácida (Termo-Jarrell-Ash, Modelo Iris/AP). Os aminoácidos foram determinados após digestão ácida e básica e separados por cromatografia de troca iônica (Hitachi modelo L-8500A). A energia foi determinada em bomba calorimétrica adiabática (PARR, Modelo 1261) usando ácido benzóico como padrão.

\subsubsection{Análises dos Aminoácidos}

O método de preparação das amostras para análise seguiu metodologia da AOAC (2000): digestão ácida em tubos de vidro lacrados sob atmosfera de nitrogênio a $110{ }^{\circ} \mathrm{C}$ com $\mathrm{HCl} 6 \mathrm{~N}$ por 24 horas. Os aminoácidos cistina e metionina foram determinados após oxidação com ácido perfórmico antes da hidrólise ácida como descrito por Moore (1963). Após a hidrólise as soluções eram filtradas a vácuo, diluídas a 0,25 $\mathrm{M}$ com $\mathrm{HCl} 0,02 \mathrm{~N}$ para ajuste ao $\mathrm{pH} 8,5$ e filtradas em membrana Millipore $(0,45 \mu \mathrm{m})$. Para análise do aminoácido triptofano, foi realizada a hidroxilação de uma amostra com hidróxido de lítio - hidrólise alcalina. Os aminoácidos livres eram separados pela coluna de troca iônica do auto analisador e os resultados processados em aplicativo específico em computador acoplado (Tabela 4). 


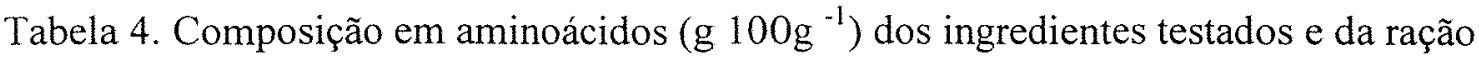
referência (matéria seca).

\begin{tabular}{llllll}
\hline Aminoácidos & RR & FP & FV & FS & FG \\
\hline Essenciais (AAE) & & & & & \\
Arginina (Arg) & 3,01 & 4,39 & 3,94 & 3,73 & 4,02 \\
Histidina (His) & 1,11 & 1,38 & 1,54 & 1,16 & 1,54 \\
Isoleucina (Ile) & 1,77 & 3,20 & 2,11 & 2,24 & 2,17 \\
Leucina (Leu) & 3,42 & 4,81 & 4,10 & 3,50 & 4,08 \\
Lisina (Lys) & 2,65 & 5,79 & 3,44 & 2,90 & 3,51 \\
Metionina (Met) & 0,55 & 1,62 & 0,83 & 0,50 & 0,81 \\
Fenilalanina (Phe) & 2,21 & 3,48 & 2,55 & 2,32 & 2,61 \\
Treonina (Thr) & 1,64 & 2,93 & 1,86 & 1,81 & 3,70 \\
Triptofano (Trp) & 0,38 & 0,42 & 0,63 & 0,65 & 0,48 \\
Valina (Val) & 1,99 & 3,93 & 3,36 & 2,29 & 3,41 \\
Total Essenciais (AAE) & 18,73 & 31,95 & 24,36 & 21,10 & 26,33
\end{tabular}

Não essenciais (AANE)

$\begin{array}{llllll}\text { Ácido Aspártico (Asp) } & 3,60 & 6,31 & 5,14 & 5,44 & 5,21 \\ \text { Ácido Glutâmico (Glu) } & 7,28 & 8,81 & 7,70 & 9,00 & 7,26 \\ \text { Alanina (Ala) } & 2,24 & 4,25 & 4,51 & 2,02 & 4,57 \\ \text { Cistina (Cys) } & 0,42 & 0,63 & 0,62 & 0,45 & 0,63 \\ \text { Glicina (Gly) } & 2,11 & 4,81 & 6,37 & 1,96 & 6,68 \\ \text { Serina (Ser) } & 1,99 & 3,77 & 2,60 & 2,31 & 2,67 \\ \text { Prolina (Pro) } & 2,72 & 4,43 & 3,97 & 2,38 & 4,21 \\ \text { Tirosina (Tyr) } & 0,67 & 2,71 & 1,81 & 1,27 & 1,59 \\ \text { Total Não Essenciais (AANE) } & 21,03 & 34,72 & 32,72 & 24,84 & 32,82 \\ & & & & & \\ \text { al de Aminoácidos (AA) } & 39,76 & 66,66 & 57,08 & 45,94 & 59,14\end{array}$

$\mathrm{RR}=$ ração referência; $\mathrm{FP}=$ farinha de peixe; $F V=$ farinha de visceras; $F S=$ farelo de soja; $F G=$ farelo de glúten de milho 
4.2.5 Determinação do coeficiente de digestibilidade aparente

As determinações dos coeficientes de digestibilidade aparente (\%) (Maynard \& Loosly, 1969) da matéria seca $\left(\mathrm{CDA}_{\mathrm{MS}}\right)$, nutrientes $\left(\mathrm{CDA}_{\mathrm{N}}\right)$, energia $\left(\mathrm{CDA}_{\mathrm{EB}}\right)$ da ração referência $\left(C D A_{R R}\right)$, dietas-teste e ingredientes protéicos foram calculados segundo Burel et al. (2000), De Silva et al. (2000) e De Silva e Anderson (1995), como segue:

$\mathrm{CDA}_{\mathrm{MS}}=100 x\left[1-\left(\frac{\mathrm{Cr}_{2} \mathrm{O}_{3} \text { dieta }}{\mathrm{Cr}_{2} \mathrm{O}_{3} \text { fezes }}\right)\right]$

$\mathrm{CDA}_{\mathrm{N} / \mathrm{EB}}=100 x\left[1-\left(\frac{\mathrm{Cr}_{2} \mathrm{O}_{3} \text { dieta }}{\mathrm{Cr}_{2} \mathrm{O}_{3} \text { fezes }}\right) x\left(\frac{\text { nutriente ou energia fezes }}{\text { nutriente ou energia dieta }}\right)\right]$

Uma vez determinado o $\mathrm{CDA}_{\mathrm{MS}}, \mathrm{CDA}_{\mathrm{N}}$ e $\mathrm{CDA}_{\mathrm{EB}}$ da ração de referência e das dietas-teste, foram então calculados os valores de $\mathrm{CDA}_{\mathrm{MS}}, \mathrm{CDA}_{\mathrm{N}}$ e $C D \mathrm{~A}_{\mathrm{EB}} \operatorname{dos}$ ingredientes protéicos isoladamente:

$\mathrm{CDA}_{\mathrm{MS}}=\left[\mathrm{CDA}_{\mathrm{MS}}\right.$ dieta-teste $\left.-\left(0,7 \times \mathrm{CDA}_{\mathrm{MS}} \mathrm{RR}\right) \div 0,3\right]$

$\mathrm{CDA}_{\mathrm{N} / \mathrm{EB}}=\left[\mathrm{CDA}_{\mathrm{N} / \mathrm{EB}}\right.$ dieta-teste $\left.-\left(0,7 \times \mathrm{CDA}_{\mathrm{N} / \mathrm{EB}} \mathrm{RR}\right) \div 0,3\right]$

\subsubsection{Análise Estatística}

Os valores de CDA dos diferentes ingredientes protéicos e RR foram submetidos a análise de variância (ANOVA; $\mathrm{P}<0,01)$ e ao teste de comparação de médias Tukey, pelo aplicativo estatístico SAS (SAS, 1985). 


\subsection{Resultados e Discussão}

A variação dos parâmetros de qualidade de água do laboratório monitorados durante a condução dos ensaios foi: pH 7,40 $\pm 0,2$; oxigênio dissolvido $6,0 \pm 0,5 \mathrm{mg} \mathrm{L}^{-1}$; amônia $<0,0009 \mathrm{mg} \mathrm{L}^{-1}$, considerados normais e dentro das condições de conforto para espécie. Independentemente dos tratamentos, as fezes coletadas apresentavam forma sólida e consistente. Não houve mortalidade de peixes alimentados com as diferentes rações durante o período de coleta de fezes e nem casos de recusa dos diferentes tipos de rações fornecidas.

Os resultados de $\mathrm{CDA}_{\mathrm{MS}}, \mathrm{CDA}$ da proteína bruta $\left(\mathrm{CDA} \mathrm{AB}_{\mathrm{PB}}\right)$, lipídios $\left(\mathrm{CDA}_{\mathrm{LP}}\right)$, energia bruta $\left(\mathrm{CDA}_{\mathrm{EB}}\right)$, cálcio $\left(\mathrm{CDA}_{\mathrm{Ca}}\right)$ e fósforo $\left(\mathrm{CDA}_{\mathrm{P}}\right)$ estão apresentados na Tabela 4. Os resultados da ANOVA revelam que o CDA de todos nutrientes dos ingredientes testados e da $R R$ apresentaram diferença entre si $(P<0,01)$. Os valores de $C_{D A}$ foram mais elevados para FV $(82,59 \pm 0,46)$ e FG $(75,29 \pm 1,33)$. Todos os valores de $\mathrm{CDA}_{\mathrm{MS}}$ dos ingredientes foram superiores em comparação aos valores de $C D A_{R R}$. Os valores de $\mathrm{CDA}_{\mathrm{PB}}$ foram bastante altos para todos os ingredientes, sendo maiores para $\mathrm{FS}$ e FG (Tabela 5).

Exceto para o FG, os lipídios presentes nos ingredientes e na RR apresentaram alto $\mathrm{CDA}$. Entretanto, o $\mathrm{CDA}_{\mathrm{EB}}$ da $\mathrm{FG}$ foi mais alto que o $\mathrm{CDA} \mathrm{AR}_{\mathrm{R}}$. A digestibilidade da EB foi alta também para FV e FP, sendo os valores mais baixos apresentados pelo FS e $\mathrm{RR}$ (Tabela 4). Considerando os dois ingredientes protéicos de origem animal, a FP

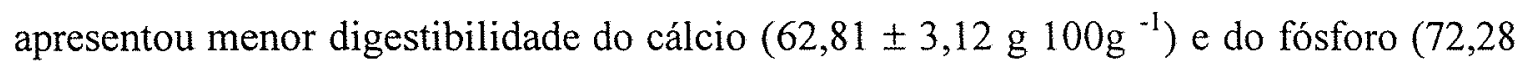

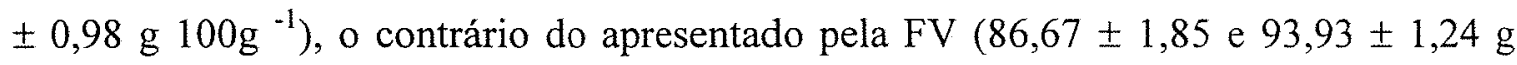
$100 \mathrm{~g}^{-1}$ ) para estes mesmo nutrientes (Tabela 4).

Foram observadas diferenças $(\mathrm{P}<0,01)$ para os $\mathrm{CDA}$ de todos os aminoácidos dos ingredientes testados. Os valores de CDA dos aminoácidos totais (CDA $\mathrm{CAAT}_{\mathrm{A}}$ ), aminoácidos essenciais $\left(\mathrm{CDA}_{\mathrm{AAE}}\right)$ e não essenciais $\left(\mathrm{CDA}_{\mathrm{AANE}}\right)$ foram diferentes entre as fontes protéicas testadas, com exceção da FP em comparação à $R R(P>0,01)$ (Tabela 6). 
Tabela 5. Coeficientes de digestibilidade (média de três repetições \pm erro padrão) da ração referência e ingredientes testados (valores seguidos do mesmo superscrito não diferem significativamente $\mathrm{P}>0,01$ ).

\begin{tabular}{lccccc}
\hline & RR & FP & FV & FS & FG \\
\cline { 2 - 6 } Digestibilidade & \multicolumn{5}{c}{$\left({\left.\mathrm{g} 100 \mathrm{~g}^{-1}\right)}\right.$} \\
\hline Matéria seca & $66,66^{\mathrm{d}} \pm 0,18$ & $69,99^{\mathrm{c}} \pm 0,83$ & $82,59^{\mathrm{a}} \pm 0,46$ & $70,42^{\mathrm{c}} \pm 0.82$ & $75,29^{\mathrm{b}} \pm 1,33$ \\
Proteína & $88,87^{\mathrm{b}} \pm 1,08$ & $87,69^{\mathrm{b}} \pm 1,27$ & $81,47^{\mathrm{c}} \pm 1,54$ & $94,30^{\mathrm{a}} \pm 1,23$ & $93,62^{\mathrm{a}} \pm 1,87$ \\
Lipídio & $95,22^{\mathrm{b}} \pm 0,72$ & $98,21^{\mathrm{a}} \pm 0,98$ & $98,19^{\mathrm{a}} \pm 1,21$ & $93,26^{\mathrm{b}} \pm 1,52$ & $83,35^{\mathrm{c}} \pm 2,02$ \\
Energia & $71,27^{\mathrm{c}} \pm 2,52$ & $78,36^{\mathrm{b}} \pm 1,23$ & $85,20^{\mathrm{a}} \pm 0,54$ & $75,37^{\mathrm{bc}} \pm 2,21$ & $76,48^{\mathrm{b}} \pm 1,87$ \\
Cálcio & $88,05^{\mathrm{a}} \pm 2,58$ & $62,81^{\mathrm{c}} \pm 3,12$ & $86,67^{\mathrm{a}} \pm 1,85$ & $81,06^{\mathrm{ab}} \pm 0,52$ & $74,50^{\mathrm{b}} \pm 0,89$ \\
Fósforo & $91,85^{\mathrm{ab}} \pm 1,12$ & $72,28^{\mathrm{d}} \pm 0,98$ & $93,93^{\mathrm{a}} \pm 1,24$ & $87,96^{\mathrm{bc}} \pm 1,74$ & $82,82^{\mathrm{c}} \pm 4,01$ \\
\hline
\end{tabular}

$R R=$ ração referência; $F P=$ farinha de peixe; $F V=$ farinha de vísceras; $F S=$ farelo de soja; $F G=$ farelo de glúten de milho 
Tabela 6. Coeficiente de digestibilidade individual dos aminoácidos essenciais $\left(\mathrm{CDA}_{\mathrm{AAE}}\right)$, não essencial $\left(\mathrm{CDA}_{\mathrm{AANE}}\right)$, total de aminoácidos essenciais $\left(\mathrm{CDA}_{\mathrm{AAET}}\right)$; total de aminoácidos não essenciais ( $\left(\mathrm{CDA}_{\mathrm{AANET}}\right)$ e total de aminoácidos $\left(\mathrm{CDA}_{\mathrm{AAT}}\right)$ da ração referência e ingredientes testados (média de 3 repetições \pm erro padrão, letras iguais não diferem significativamente $\mathrm{P}>0,01$ pelo teste Tukey).

\begin{tabular}{|c|c|c|c|c|c|c|c|}
\hline \multirow{2}{*}{ Aminoácidos } & \multicolumn{5}{|c|}{ Coeficientes de digestibilidade (CDA) } & \multirow{2}{*}{$\begin{array}{c}\text { Erro } \\
\text { padrão }\end{array}$} & \multirow{2}{*}{$\begin{array}{c}A N O V A \\
\operatorname{Pr}>\mathrm{F}\end{array}$} \\
\hline & RR & FP & FV & FS & PR & & \\
\hline \multicolumn{8}{|l|}{ AAE } \\
\hline Arg & $93,13^{a} \pm 2,45$ & $92,50^{\text {bc }} \pm 0,85$ & $91,21^{c} \pm 0,89$ & $97,77^{\mathrm{a}} \pm 0,21$ & $98,37^{\mathrm{a}} \pm 0,11$ & 0,49 & 0,0001 \\
\hline His & $90,10^{a b} \pm 0,32$ & $85,83^{b} \pm 0,41$ & $93,14^{a} \pm 0,11$ & $90,97^{a b} \pm 0,46$ & $91,87^{\mathrm{a}} \pm 0,31$ & 1,42 & 0,0042 \\
\hline Ile & $88,27^{\mathrm{b}} \pm 0,46$ & $88,85^{\mathrm{b}} \pm 0,32$ & $85,75^{b} \pm 0,78$ & $96,49^{\mathrm{a}} \pm 0,41$ & $94,88^{a} \pm 0,87$ & 1,40 & 0,0002 \\
\hline Leu & $89,37^{b} \pm 0,25$ & $85,68^{b} \pm 0,74$ & $88,62^{b} \pm 0,14$ & $97,62^{\mathrm{a}} \pm 0,47$ & $88,94^{b} \pm 0,85$ & 1,25 & 0,0001 \\
\hline Lys & $92,23^{b} \pm 0,41$ & $95,77^{\mathrm{a}} \pm 0,08$ & $90,82^{6} \pm 0,78$ & $96,14^{\mathrm{a}} \pm 0,24$ & $95,86^{a} \pm 0,73$ & 0,63 & 0,0001 \\
\hline Met & $86,35^{a} \pm 0,87$ & $82,65^{\mathrm{a}} \pm 1,03$ & $71,28^{b} \pm 0,41$ & $80,26^{a} \pm 0,55$ & $83,14^{a} \pm 0,19$ & 2,09 & 0,0006 \\
\hline Phe & $90,68^{\mathrm{bc}} \pm 0,85$ & $91,05^{\mathrm{b}} \pm 0,20$ & $87,47^{c} \pm 0,98$ & $94,70^{a} \pm 0,89$ & $93,06^{\text {ab }} \pm 1,42$ & 0,92 & 0,0003 \\
\hline Thr & $86,14^{b} \pm 0,33$ & $88,03^{b} \pm 0,85$ & $86,07^{b} \pm 0,19$ & $96,28^{a} \pm 1,23$ & $95,51^{\mathrm{a}} \pm 0,56$ & 1,89 & 0,0006 \\
\hline Trp & $92,84^{*} \pm 0,77$ & $82,24^{b} \pm 0,87$ & $51,52^{c} \pm 0,76$ & $86,57^{\mathrm{ab}} \pm 0,51$ & $79,97^{b} \pm 0,71$ & 1,95 & 0,0001 \\
\hline Val & $85,83^{c} \pm 0,21$ & $91,98^{b} \pm 0,44$ & $82,96^{\circ} \pm 1,23$ & $98,60^{a} \pm 0,54$ & $97,05^{a} \pm 0,87$ & 0,95 & 0,0001 \\
\hline$A A E T$ & $89,79^{c} \pm 0,74$ & $89,81^{c} \pm 0,81$ & $86,92^{d} \pm 0,93$ & $95,90^{\mathrm{a}} \pm 0,74$ & $93,55^{b} \pm 0,11$ & 0,56 & 0,0001 \\
\hline \multicolumn{8}{|l|}{ AANE } \\
\hline Asp & $88,19^{c} \pm 0,73$ & $84,95^{\text {cd }} \pm 0,19$ & $82,02^{\mathrm{d}} \pm 0,81$ & $99,56^{a} \pm 1,52$ & $93,75^{b} \pm 0,31$ & 1,22 & 0,0001 \\
\hline Glu & $93,04^{b} \pm 0,48$ & $91,06^{b} \pm 0,87$ & $87,46^{\mathrm{c}} \pm 0,55$ & $99,79^{a} \pm 0,71$ & $93,14^{b} \pm 0,89$ & 0,66 & 0,0001 \\
\hline Ala & $87,11^{b} \pm 0,77$ & $87,46^{b} \pm 0,16$ & $87,55^{b} \pm 0,45$ & $99,43^{a} \pm 0,44$ & $97,01^{a} \pm 0,12$ & 0,74 & 0,0001 \\
\hline Cys & $88,72^{a} \pm 0,42$ & $41,47^{c} \pm 1,01$ & $50,38^{d} \pm 0,53$ & $51,15^{b} \pm 0,99$ & $56,19^{b} \pm 0,75$ & 1,79 & 0,0001 \\
\hline Gly & $86,40^{c} \pm 0,19$ & $91,39^{\mathrm{bc}} \pm 1,89$ & $93,13^{b} \pm 0,14$ & $99,90^{\mathrm{a}} \pm 1,13$ & $99,35^{\mathrm{a}} \pm 0,87$ & 1,45 & 0,0001 \\
\hline Ser & $87,99^{c} \pm 0,71$ & $87,30^{c} \pm 0,09$ & $77,03^{d} \pm 0,93$ & $99,74^{a} \pm 0,44$ & $91,78^{\mathrm{b}} \pm 0,66$ & 0,97 & 0,0001 \\
\hline Pro & $90,43^{b} \pm 1,11$ & $92,79^{b} \pm 0,71$ & $89,17^{b} \pm 0,99$ & $99,86^{\mathrm{a}} \pm 0,49$ & $97,90^{\star} \pm 0,65$ & 1,07 & 0,0001 \\
\hline Tyr & $79,60^{\mathrm{b}} \pm 0,19$ & $95,93^{a} \pm 0,55$ & $96,21^{\sharp} \pm 1,13$ & $98,18^{a} \pm 0,73$ & $94,66^{a} \pm 0,61$ & 1,40 & 0,0001 \\
\hline AANET & $89,52^{c} \pm 0,91$ & $87,91^{c} \pm 1,26$ & $84,74^{d} \pm 0,85$ & $98,79^{3} \pm 0,88$ & $93,64^{b} \pm 0,79$ & 0,55 & 0,0001 \\
\hline AAT & $89,65^{c} \pm 0,29$ & $88,83^{c} \pm 0,32$ & $85,73^{d} \pm 0,91$ & $97,45^{a} \pm 0,85$ & $93,60^{b} \pm 1,01$ & 0,49 & $0,000 I$ \\
\hline
\end{tabular}

$\mathrm{RR}=$ ração referência; $\mathrm{FP}=$ farinha de peixe; $\mathrm{FV}=$ farinha de vísceras; $\mathrm{FS}=$ farelo de soja; $\mathrm{FG}=$ farelo de glúten de milho.

A acurácia na determinação dos CDA é definida pelo sistema ou método de coleta das fezes utilizados nos experimentos de digestibilidade com peixes. As fezes podem ser coletadas por diferentes métodos como a dissecação, compressão ou sucção anal (Small et al., 1999; Thodesen \& Storebakken, 1998; Storebakken et al., 2000; 
Spyridakis et al., 1989; Sullivan \& Reigh, 1995); filtração ou coleta contínua automática (Burel et al., 2000; Choubert et al., 1982, 1979); pipetagem das fezes no aquário (Spyridakis et al., 1989); ou por câmaras metabólicas (Smith et al., 1980). Todos estes métodos têm sido amplamente discutidos e revisados por diversos pesquisadores (Cho et al., 1982; De Silva \& Anderson, 1995; Steffens, 1989; Watanabe, 1988).

Segundo Anderson et al. (1992) é necessário minimizar ao máximo as perdas de nutrientes por lixiviação na água quando se utiliza dos métodos de coleta com o peixe dentro da água, a fim de evitar super estimativas dos valores de CDA dos nutrientes (Windell et al., 1978). Os métodos por sedimentação e compressão abdominal são os mais utilizados e discutidos em experimentos de digestibilidade (Alexis et al., 1995; Allan et al., 2000; Bureau et al., 1999; De Silva et al., 2000; Mu et al., 2000; Spyridakis et al., 1989). Entretanto, ambos estão também sujeitos a erros na determinação dos valores dos CDA dos nutrientes em função de falhas na metodologia (Bureau et al., 1999; De La Noüe \& Choubert, 1986; Hajen et al., 1993a; Vens Cappell, 1985; Windell et al., 1978).

O mesmo é verdade em relação ao marcador utilizado (Tacon \& Rodrigues, 1984; Kabir et al., 1998; Weatherup \& McCracken, 1998). A opção pelo uso do $\mathrm{Cr}_{2} \mathrm{O}_{3}$ neste estudo deve-se ao fato do mesmo ser amplamente utilizado em experimentos de digestibilidade em função da simplicidade de aplicação e precisão na metodologia de análise (Austreng, 1978; De Silva et al., 1997; Degani et al., 1987; Kabir et al., 1998).

Os valores de $\mathrm{CDA}_{\mathrm{MS}}$ determinados neste estudo contrapõem-se aos resultados publicados por Sullivan \& Reigh (1995) para "sunshine bass" (Morone saxatilis x M. chrysops), que apresentou $\mathrm{CDA}_{\mathrm{MS}}$ dos ingredientes de origem animal maiores que para os ingredientes de origem vegetal, sugerindo uma baixa digestibilidade dos carboidratos destes últimos. Trabalhando com "stripped bass" (Morone saxatilis), Small et al. (1999) demonstraram que o $\mathrm{CDA}_{\mathrm{MS}}$ dos ingredientes de origem vegetal eram maiores em comparação aos ingredientes de origem animal, estes resultados corroboram com os resultados observados neste estudo. Embora entre os objetivos deste estudo não esteja a determinação do CDA dos carboidratos dietéticos, através do resultado do CDA $\mathrm{MS}_{\mathrm{MS}}$ seria possível concluir que este nutriente apresentou alta digestibilidade em ambos 
ingredientes de origem vegetal testados. Os mecanismos fisiológicos de utilização dos carboidratos em peixes carnivoros ainda não é bem entendido e são poucos os estudos feitos nesta área (Erfanullah \& Jafri, 1999; Hillestad et al., 2001; Wilson, 1994).

Os CDA da proteína e energia da FP para o black bass mantiveram-se próximos aos valores relatados por Sullivan \& Reigh (1995) e Small et al. (1999). Em ambos os trabalhos foram determinados os CDA da FP respectivamente para o "stripped bass" e o "sunshine bass" através do método de compressão abdominal, utilizando o óxido de cromio como marcador.

O black bass digeriu eficientemente a proteína e a energia de todos os ingredientes testados. Os resultados de CDA dos nutrientes ficaram próximos aos apresentados por diversos trabalhos com peixes carnívoros (Alexis et al., 1995; Allan et al., 2000; De Silva et al., 2000; Hajen et al., 1993b; NRC, 1993; Small et al., 1999). Este fato demonstra que fontes protéicas de origem vegetal podem ser perfeitamente utilizadas na composição das rações utilizadas para criação de peixes carnívoros, diminuindo assim a dependência da farinha de peixe como fonte primária de proteína e o custo final da ração (Rumsey, 1993).

O CDA dos nutrientes da FV foi maior que aqueles apresentados por Cho \& Slinger (1979) e Cho et al. (1982), NRC (1993). Cho \& Slinger (1979) encontraram CDA de 68\% para FV quando as amostras de fezes foram coletadas pelo sistema de sedimentação. Os resultados do presente estudo (Tabela 4) são semelhantes aos encontrados por Pfeffer et al. (1995), que observaram CDA de 82 e $81 \%$ para proteína e energia da FV, respectivamente, trabalhando com truta arco-íris, com amostras de fezes coletadas pelo método de compressão abdominal. Hajen et al. (1993a) observaram CDA de $85 \%$ para FV em experimentos com salmão Chinook coletando amostras de fezes pelo sistema de sedimentação.

Cho et al. (1982), NRC (1993), Sargent et al. (1989) e Sullivan \& Reigh (1995) relataram altos CDA para o lipídio que compõe vários ingredientes protéicos testados na alimentação e nutrição de espécies carnívoras, corroborando resultados observados no presente estudo (Tabela 4). Steffens (1989) considera que a baixa digestibilidade da proteína em fontes protéicas de origem animal pode estar relacionada à formação de 
complexos oxidados de gordura e proteína. Este fato poderia explicar a menor digestibilidade protéica da FV já que este ingrediente apresentou um alto teor de lipídio (Tabela 3).

Fontes protéicas de origem vegetal normalmente apresentam baixa concentração dos aminoácidos lisina, metionina, treonina e triptofano em comparação a fontes protéicas de origem animal como a farinha de peixe. O farelo de glúten, em particular, apresenta baixas concentrações de arginina e lisina (Tabela 5).

Os resultados das análises conduzidas revelaram que os ingredientes testados e a RR apresentavam baixos conteúdos de cistina (Tabela 5); o CDA deste aminoácido também foi baixo (Tabela 6). Segundo Anderson et al. (1992) baixos conteúdos de cistina, além de outros aminoácidos, em um particular ingrediente podem ser atribuídos à ocorrência de super aquecimento durante o processamento, e oxidação durante o armazenamento das fontes protéicas em geral. De Silva \& Anderson (1995) citam que a cistina pode ser sintetizada a partir da serina ou da metionina, pela ação da enzima 3fosfoglicerato. Como a cistina não é um AAE, o reduzido conteúdo deste nutriente nos ingredientes testados possivelmente não interferiu no desempenho e metabolismo do black bass. Small et al. (1999) também determinaram baixos CDA para a cistina trabalhando com fontes protéicas idênticas àquelas utilizadas neste estudo em experimentos com "stripped bass" Morone saxatilis.

Os baixos CDA dos aminoácidos totais da FP e FV podem estar associados ao tipo de processamento utilizado na fabricação destas farinhas (Tabela 6). O tempo de estoque, quantidade de óleo extraído e qualidade da matéria prima utilizada - peixe inteiro, vísceras, escamas, pele, etc. - podem afetar a qualidade da proteína e, principalmente, a disponibilidade dos aminoácidos contidos nestes ingredientes (Anderson et al., 1992; Contreras, 1999).

A oxidação de lipídios pode causar a formação de peróxidos que podem complexar as proteínas através de ligações físicas e covalentes (Nelson \& Cox, 2000). Ligações covalentes entre produtos oxidados e proteínas podem destruir aminoácidos como o triptofano, oxidar a metionina e ligar a lisina a outros compostos fazendo destes aminoácidos indisponíveis (Nielsen et al., 1985). Isto pode explicar o baixo conteúdo de 


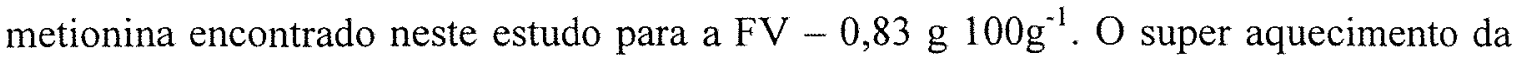
FP durante o processamento pode causar a perda de aminoácidos pela oxidação, pela complexação com peróxidos e também através da reação de Mailard (Davidek et al., 1990).

Anderson et al. (1992) citam que carboidratos contidos nas dietas-teste utilizadas para avaliação da digestibilidade de ingredientes também podem interferir na digestão ácida dos aminoácidos pelos peixes, resultando em uma baixa utilização dos aminoácidos originados da FP quando combinados aos carboidratos nas rações. Apesar do FS apresentar baixos conteúdos de aminoácidos totais (AAT) (Tabela 5), este ingrediente apresentou um dos melhores $\mathrm{CDA}_{\mathrm{AAT}}$ (Tabela 6). Aparentemente os resultados demonstram que não houve interferência de fatores antinutricionais (e.g. inibidores de tripsina, ácido fítico e hemaglutininas) na digestibilidade dos aminoácidos pelo black bass, o que não corrobora resultados encontrados em avaliações deste ingrediente na nutrição de outros peixes carnívoros (Anderson et al., 1992; Arnesen et al., 1989; De Silva et al., 2000).

Os altos $C_{D A} A_{A A E}, C D A_{A A N E}$ e $C D A_{A A T}$ e $C D A_{P B}$ para $F S$ e FG podem ser explicados pelo fato de os processos de fabricação destes ingredientes removerem grande quantidade do amido contido na matéria prima, indigerível para espécies carnívoras, aumentando a disponibilidade dos aminoácidos (Scott et al., 1982).Os CDA dos aminoácidos arginina, lisina, valina, alanina, glicina, e prolina, principalmente, da FS e FG foi de aproximadamente $100 \%$. Embora comum em espécies onívoras tropicais, normalmente este fenômeno não é observado em peixes carnívoros de águas temperadas (Bakke-McKellep et al., 2000) e podem, provavelmente, ser atribuídos a uma discreta superestimativa do CDA destes nutrientes em função da metodologia utilizada, combinação de nutrientes ou microflora presente no intestino do peixe (Austin \& AlZahrani, 1988; Muroga, et al., 1987; Ringø et al., 1995; Sugita, 1987; Sugita et al., 1989; Sugita et al., 1991).

Vegetais produzem fitatos que são estocados na forma de ácido fítico e podem permanecer nos ingredientes após o processamento das fontes protéicas de origem vegetal. Peixes que possuem uma fase de digestão ácida, como é o caso das espécies 
carnívoras, apresentam uma menor capacidade de digerir o fósforo na forma de fitato (Bransden \& Carter, 1999). Este fato poderia explicar a menor digestibilidade do fósforo nos ingredientes FS e FG. O fósforo na forma de fitato pode ainda formar complexos biologicamente indisponíveis aos peixes, normalmente ligados a aminoácidos e proteínas, que podem reduzir a biodisponibilidade da proteína e de alguns minerais tais como zinco, manganês, cobre, molibdênio, cálcio, magnésio e ferro (NRC, 1993). Uma forma de minimizar estes efeitos seria a inclusão de fontes de fitase nas dietas, visando desativar o ácido fítico e disponibilizar o nutriente complexado (Rodehutscord \& Pfeffer, 1995; Schäfer et al., 1995).

\subsection{Conclusões}

Estes resultados demonstram a necessidade e importância da determinação da digestibilidade dos ingredientes protéicos, visando maior precisão na formulação de rações de custo mínimo para peixes carnívoros. Em adição, este estudo mostra que a disponibilidade dos aminoácidos dos ingredientes protéicos é bastante variável, devido principalmente a qualidade de origem e processamento destas fontes protéicas. Pode-se concluir ainda que a o farelo de soja e o farelo de glúten podem ser utilizados como substitutos parciais das fontes protéicas de origem animal nas rações formuladas para o black bass. A farinha de vísceras pode ser considerada um boa opção como fonte protéica animal em rações de peixes carnívoros, uma vez que possui boa digestibilidade, padrão de aminoácidos adequado e alta disponibilidade do fósforo. 


\section{SUBSTITUIÇÃO DA FARINHA dE PEIXE PELA FARINHA dE VÍSCERAS EM RAÇÕES COMERCIAIS PARA O CARNÍVORO BLACK BASS Micropterus salmoides}

\section{RESUMO}

A produção mundial da farinha de peixes (FP) está comprometida pela drástica diminuição da pesca extrativa e a farinha de vísceras de abatedouro avícola (FV) surge como fonte protéica alternativa, de baixo custo e de alto valor biológico para a indústria da alimentação de peixes. Com o objetivo de avaliar o efeito da substituição da farinha de peixe pela farinha de vísceras em rações para peixes carnívoros, foram formuladas, com base no conceito de proteína ideal, seis dietas comerciais isonitrogenadas ( $43 \%$ proteína) e isocalóricas $(3.870 \mathrm{kcal} / \mathrm{kg})$ contendo proporções crescentes de FV 20FP:0FV; 0FP:20FV; 5FP:20FV; 10FP:15FV; 15FP:10FV; 20FP:5FV, e administradas a juvenis de black bass Micropterus salmoides $(21,0 \pm 1,5 \mathrm{~g})$, em dois ensaios desempenho e digestibilidade - em um delineamento experimental totalmente ao acaso $(n=4)$. As dietas que continham farinha de vísceras mostraram melhores resultados de ganho de peso, conversão alimentar, retenção protéica e energética $(P<0,05)$. Com exceção do fósforo, houve diferença significativa $(\mathrm{P}<0,05)$ para os coeficientes de digestibilidade aparente da matéria seca, proteína, extrato etéreo, fibra bruta, energia e cálcio. O presente estudo demonstrou que a inclusão de $20 \%$ de FV em substituição à FP em rações para peixes carnívoros é tecnicamente possível e economicamente viável. 


\section{SUMMARY}

Replacement of fish meal by poultry by-product meal in commercial diets for the carnivorous largemouth bass Micropterus salmoides

As the world production of the fish meal (FM) is hampered by the decrease of the capture fisheries, poultry by-product meal (PM) stars being use as a low cost, good quality alternative protein source for the fish feeding industry. This work aims to evaluate the effects of the substitution of FM by PM in carnivorous fish feeds, formulated by the concept of ideal protein. Six commercial, iso-nitrogenous ( $43 \%$ protein) and iso-energetic ( $3.870 \mathrm{kcal} / \mathrm{kg}$ ) diets, containing increasing contents of $\mathrm{PM}$ 20FM:0PM; 0FM:20PM; 5FM:20PM; 10FM:15PM; 15FM:10PM; 20FM:5PM, were fed to largemouth bass Micropterus salmoides $(21,0 \pm 1,5 \mathrm{~g})$, set up in two trials performance and digestibility - in a completely randomized design $(n=4)$. Diets containing PM led to better performance, feed conversion ratio, dietetic protein and energy retention $(\mathrm{P}<0,05)$. Except for the phosphorus, differences were detected $(\mathrm{P}<0,05)$ for the apparent digestibility of dry matter, protein, lipids, crude fiber, energy and calcium. Results allow to infer that the inclusion of $20 \%$ PM in substitution to FM in feeds for carnivorous fish is technically possible and economically feasible.

\subsection{Introdução}

Entre os ingredientes que compõem uma ração para espécies carnivoras, os alimentos protéicos são considerados os mais importantes, uma vez que estes peixes possuem uma capacidade inata de utilizar a proteína dietética como fonte de energia (Tacon \& Cowey, 1985). As rações representam o maior percentual no custo da produção de peixes carnívoros, normalmente produzidos em regime intensivo, afetando diretamente o desenvolvimento deste ramo da piscicultura (Naylor et al., 2000). O aumento dos custos de produção das farinhas e óleos de pescado observado nas últimas 
décadas pode comprometer em definitivo o desenvolvimento e a rentabilidade de grandes empreendimentos na área da piscicultura (Tacon, 1996).

Pesquisas para seleção de possíveis substitutos para farinha de peixe são tendenciosas, sempre relacionadas à soja ou farelo de soja, "commodities" que cujo preço está vinculado ao dólar americano; às farinhas de sangue, carne e osso e carne, que sofrem restrições em função de problemas sanitários (e.g. mal da vaca louca) e às proteínas microbianas, que ainda apresentam problemas de disponibilidade (Webster et al., 1999; Tacon, 1994). A utilização destas fontes protéicas alternativas, de origem animal ou vegetal, ainda demandam uma avaliação mais precisa do seu valor biológico para os peixes (Boonyaratpalin et al., 1998; Gomes et al., 1995; Kikuchi, 1999; Webster et al.,1999; Webster et al, 2000). As quantidades de farinha de peixe já foram bastante reduzidas na maioria das rações de peixes carnívoros. Restam, entretanto, várias dúvidas e problemas a serem equacionados em relação balanço em aminoácidos, presença de polissacarídeos amiláceos e estruturais e à baixa digestibilidade das fontes de proteína de origem vegetal (Ozório et al., 2001).

A farinha de vísceras é um subproduto da indústria avícola que vem sendo utilizado como fonte alternativa de proteína na indústria da alimentação animal, apresentando grande disponibilidade, preço accessível e alta qualidade (Maffi, 1993). Pesquisas vêm então sendo realizadas na tentativa de se utilizar com eficiência este ingrediente em dietas para peixes (Fowler, 1991; Webster et al., 1999; Giri et al., 2000; Webter et al., 2000).

Avaliando rações com diferentes fontes protéicas para o híbrido "sunshine bass" Morone chrysops x Morone saxatilis, Webster et al. (1999) observaram resultados de desempenho idênticos quando os peixes foram alimentados com dietas que tinham a composição protéica baseada em $32 \%$ de farelo de soja e $28 \%$ de farinha de vísceras ou $25,5 \%$ de farelo de soja e $30 \%$ de farinha de peixe; mesmo assim os autores consideraram que nem sempre a farinha de peixe pode ser substituída totalmente. Giri et al. (2000) demonstraram que o bagre africano Clarias batrachus Linn. apresenta redução no ganho de peso, conversão alimentar e retenção protéica quando o farinha de peixe é completamente substituída pela farinha de vísceras nas dietas para a espécie. 
O farelo de soja é considerado uma das mais nutritivas fontes de proteína de origem vegetal. Entretanto, vários autores observaram que quanto maior a porcentagem de inclusão desta fonte protéica em rações para peixes carnívoros, piores os resultados de desempenho, conversão alimentar, taxa de eficiência protéica e retenção protéica (Webster et al., 2000, Boonyaratpalin, et al., 1998; Kaushik et al., 1995).

Como forma de solucionar possíveis problemas na deficiência em aminoácidos, vários estudos citam a importância da suplementação de aminoácidos sintéticos nas rações. Mambrini et al. (1999) em experimentos com truta arco-íris (Oncorhynchus mykiss) suplementaram níveis crescentes de DL-metionina em rações que utilizavam o farelo de soja como única fonte protéica, e observaram uma melhora no desempenho das trutas devido ao aumento da taxa de consumo alimentar.

Webster et al. (1995) demonstraram que rações formuladas com farelo de soja em substituição à farinha de peixe, contendo $35 \%$ de proteína e suplementadas com fosfato bicálcico e L-metionina, podem ser utilizadas na alimentação de juvenis do bagre azul Ictalurus furcatus, sem que ocorram efeitos adversos no crescimento e na composição da carcaça. Entretanto, deve-se notar que a fim de atenuar possíveis problemas com a palatabilidade e equilibrar ácidos graxos essenciais nas dietas, Webster et al. (1995) equilibraram as fontes de energia das rações com óleo de fígado de peixe. Finalmente, estes autores recomendam que quando o nível protéico na ração é inferior a $30 \%$, as rações contenham um percentual mínimo de farinha de peixe, uma vez que, nestas condições, o valor biológico dos aminoácidos provenientes da soja fícaria abaixo do que é exigido pela espécie.

Em estudos com juvenis de "sea bass" alimentados com rações onde a proporção da substituição da farinha de peixe pelo farelo de soja foi de $37 \%$, não foram observadas redução no crescimento e na taxa de consumo alimentar. Quando a proporção de substituição era aumentada acima deste nível, foi observada uma redução no crescimento provavelmente devido a redução na taxa de consumo. Os autores do estudo, Boonyaratpalin et al, (1998), consideraram que a farinha de peixe foi melhor utilizada pelos juvenis de "sea bass" do que os produtos derivados da soja. Mais recentemente, em estudo de substituição de farinha de peixe por fontes protéicas 
vegetais, Burel et al. (2000) concluíram que, desde que tratadas por processo de extrusão, fontes vegetais podem substituir até $50 \%$ da farinha de peixe na dieta do tunídeo Psetta maxima sem afetar o desempenho, eficiência alimentar e qualidade da carcaça da espécie, mesmo que as dietas apresentem deficiência em lisina e metionina.

Para calcular o custo efetivo de uma ração são necessários conhecimentos sobre as exigências nutricionais dos peixes e principalmente sobre a digestibilidade dos nutrientes dos ingredientes envolvidos na formulação da ração (Tacon, 1994). Utilizando programas lineares de formulação de custo mínimo, Allan et al. (2000) apresentaram resultados sobre a viabilidade na utilização de fontes protéicas alternativas como farinhas de subprodutos animais e vegetais, normalmente adquiridas a um custo muito menor em comparação à farinha de peixe.

O objetivo deste estudo foi avaliar o efeito da substituição parcial e total da farinha de peixe no desempenho, composição corporal e digestibilidade de rações comerciais formuladas com base no conceito de proteína ideal para o black bass Micropterus salmoides, utilizando como fonte protéica alternativa base a farinha de vísceras de frango de alta qualidade.

\subsection{Material e Métodos}

O experimento foi conduzido no Laboratório de Nutrição de Peixes do Departamento de Produção Animal da Escola Superior de Agricultura Luiz de Queiroz, Campus Luiz de Queiroz da Universidade de São Paulo, em Piracicaba, SP $\left(22^{\circ} 42^{\prime} 30^{\prime \prime}\right.$; $47^{\circ} 38^{\prime} 00^{\prime \prime} \mathrm{W}$; altitude $546 \mathrm{~m}$ ). O laboratório conta com sistema fechado de recirculação de água com temperatura controlada por bomba de troca de calor $\left(26 \pm 0,5{ }^{\circ} \mathrm{C}\right)$, é iluminado por 8 lâmpadas de halogênio de $370 \mathrm{~W}$, controladas por temporizador, mantendo um fotoperíodo de 14L:10E, segundo recomendações de Heinen (1998). O monitoramento dos parâmetros de qualidade da água foi feito duas vezes ao dia através de equipamentos eletrônicos: medidor de pH marca Hanna HI 1280; medidor de 
oxigênio marca Mettler modelo MO 128; amônia e nitrito através do kit de análise de água modelo HACH/FF-2.

\subsubsection{Experimento 1 - Desempenho}

Com base nos valores de exigências nutricionais em aminoácidos calculados pelo conceito de proteína ideal (Tabela 1), foram formuladas seis dietas comerciais (Tabela 2) isonitrogenadas (43\% proteína) e isocalóricas (3.870 kcal $/ \mathrm{kg}$ ) (Portz et al; 2001). Os valores disponíveis de proteína, aminoácidos, energia, cálcio e fósforo da farinha de peixe, farinha de vísceras, farelo de soja e farelo de glúten de milho foram utilizados na matriz de formulação (Brill Formulations ${ }^{\circledR}$ ), a partir de dados originais de pesquisa de Portz \& Cyrino (em preparação).

Tabela 1. Perfil de aminoácidos essenciais do tecido muscular do black bass e

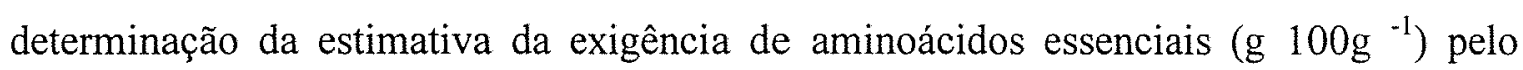
conceito de proteína ideal.

\begin{tabular}{lcccc}
\hline & $\begin{array}{c}\text { Aminoácidos essenciais } \\
\text { da carcaça }\end{array}$ & Taxa de aminoácidos essenciais & \multicolumn{2}{c}{ Exigéncias nutricionais } \\
\cline { 5 - 5 } & 6,0733 & & Determinado $^{1}$ & Estimado \\
\hline Arginina & 2,0643 & 74,2049 & - & 1,94 \\
Histidina & 3,4720 & 25,2220 & - & 0,65 \\
Isoleucina & 6,9369 & 42,4217 & 1,11 \\
Leucina & 8,1845 & 84,7565 & - & 2,21 \\
Lisina & 2,7541 & 100 & 2,61 & \\
Metionina & 3,6982 & 33,6501 & - & 0,89 \\
Fenilalanina & 4,1762 & 45,1854 & - & 1,19 \\
Treonina & 5,8233 & 51,0257 & - & 1,32 \\
Triptofano & 10,0592 & - & 0,26 \\
Valina & 3,8286 & 46,7787 & - & 1,22 \\
Ác. Aspártico & 9,5077 & 116,1671 & - & 3,03 \\
Ác. Glutâmico & 13,5343 & 165,3650 & - & 4,32 \\
Alanina & 5,6048 & 68,4807 & - & 1,79 \\
Cistina & 0,8849 & 10,8119 & - & 0,28 \\
Glicina & 5,7556 & 70,3231 & - & 1,83 \\
Serina & 3,8554 & 47,1061 & - & 1,23 \\
Prolina & 3,3554 & 40,9970 & - & 1,07 \\
Tirosina & 3,1095 & 37,9925 & - & 0,99 \\
\hline
\end{tabular}

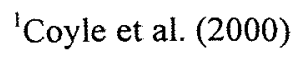


Os ingredientes protéicos de origem animal foram incluídos de forma fixa em proporções que variavam de 0 a $20 \%$, definindo os seis tratamentos - 20FP:0FV; 0FP:20FV; 5FP:20FV; 10FP:15FV; 15FP:10FV; 20FP:5FV. As fontes protéicas vegetais, a DL-metionina (98\%) e L-lisina (80\%) foram adicionadas automaticamente pelo programa de formulação no ajuste e balanceamento dos nutrientes e aminoácidos disponíveis. O óleo de salmão foi incluído com função palatabilizante e suplementação em 0,5\% dos ácidos graxos essenciais EPA e DHA (Tidwell et al., 1996).

Os ingredientes foram moídos em peneira de $1,5 \mathrm{~mm}$ e homogeneizados e misturados (misturador tipo " $\mathrm{Y}$ "), adicionados de $0,5 \%$ do indicador inerte $\mathrm{Cr}_{2} \mathrm{O}_{3}$, umedecidos com $20 \%$ de água destilada e granulados $(4,0 \mathrm{~mm})$. As rações foram secas em estufa de ventilação forçada a $45^{\circ} \mathrm{C}$ por 24 horas e armazenadas em recipientes plásticos, herméticos, sob refrigeração $\left(4^{\circ} \mathrm{C}\right)$ até sua utilização.

Trezentos e sessenta juvenis de black bass $(21,0 \pm 1,5 \mathrm{~g})$ já condicionados a aceitar o alimento artificial seco, flutuante, para peixes carnívoros (Lovshin \& Rushing, 1989), foram distribuídos em gaiolas de volume igual a 60 litros (15 peixes/gaiola), confeccionadas em tela de policroleto de vinila atóxico com abertura de malha de $5 \mathrm{~mm}$, alojadas em tanques de polipropileno de $1000 \mathrm{~L}$, em um delineamento experimental totalmente ao acaso $(n=4)$. Para montagem do experimento, os peixes foram submetidos a jejum por 24 horas, anestesiados em solução de benzocaína 1\%, pesados em balança semi-analítica com precisão de $0,001 \mathrm{~g}$ e aleatoriamente distribuídos nas parcelas. Um lote de 10 peixes foi sacrificado por superdosagem em benzocaína, enxaguado, triturado, congelado de imediato por imersão em nitrogênio líquido e armazenado em super congelador $\left(80^{\circ} \mathrm{C}\right)$, para determinação da composição corporal inicial (matéria original).

Os peixes foram alimentados em três refeições diárias $(07 \mathrm{~h} 30 \mathrm{~m}, 12 \mathrm{~h} 30 \mathrm{~m}$ e $17 \mathrm{~h} 30 \mathrm{~m}$ ) por 63 dias. Os grânulos da ração eram administrados um a um até a saciedade. As taxas de alimentação foram calculadas e expressas pela relação percentual entre o consumo de alimento diário e a biomassa de cada parcela. Houve $100 \%$ de sobrevivência durante todo período experimental.

No final do experimento, após jejum de 24 horas, os peixes foram anestesiados e foi obtido o peso final de cada parcela. Uma amostra de dez peixes de cada parcela foi 
aleatoriamente coletada. Seis peixes de cada parcela foram sacrificados e armazenados como descrito anteriormente para posterior análise da composição corporal (matéria original). Quatro peixes de cada parcela foram utilizados para registro do peso vivo e da víscera, para cálculo da relação víscero-somática. Após remoção do coração suas vísceras juntamente com a gordura acumulada na cavidade abdominal foram finamente trituradas, armazenadas em tubos de Falcon de $15 \mathrm{~mL}$, congelados por imersão em nitrogênio líquido e armazenados em super congelador $\left(-80^{\circ} \mathrm{C}\right)$, para posterior determinação da quantidade de lipídio.

As análises químico-bromatológicas dos ingredientes, dietas, carcaça e vísceras (Tabelas 2, 3 e 4), foram feitas em triplicatas com base na matéria original e seguiram os procedimentos metodológicos da "Official Methods of Analysis of the Association of Official Analytical Chemists" (AOAC, 1984), sob padronização do Compêndio Basileiro de Nutrição Animal (MAA, 1998). A proteína bruta foi analisada pelo método Kjeldahl $(\mathrm{N} \times 6,25)$ em auto-analisador LECO modelo FP-428. O extrato etéreo foi determinado após extração por éter de petróleo pelo método de Soxhlet e a fibra bruta pelo método de Weende. Cálcio, fósforo e cromio foram determinados por espectrofotometria de absorção atômica (plasma) após mineralização e digestão ácida (Termo-Jarrell-Ash, Modelo Íris/AP). A energia foi estimada em uma bomba calorimétrica adiabática (PARR Mod. 1261), usando ácido benzóico como padrão. Os aminoácidos das rações foram determinados após digestão ácida e básica e separados por cromatografia de troca iônica (Hitachi modelo L-8500A). 
Tabela 2. Ingredientes e níveis nutricionais analisados nas dietas experimentais (matéria seca).

\begin{tabular}{|c|c|c|c|c|c|c|c|}
\hline \multirow[b]{2}{*}{ Ingredientes } & \multicolumn{6}{|c|}{ Dietas } & \multirow{2}{*}{$\begin{array}{l}\text { Custo } \\
\text { (U\$/ton) }\end{array}$} \\
\hline & 20P:0V & $0 \mathrm{P}: 20 \mathrm{~V}$ & $5 \mathrm{P}: 20 \mathrm{~V}$ & $10 \mathrm{P}: 15 \mathrm{~V}$ & $15 \mathrm{P}: 10 \mathrm{~V}$ & 20P:5V & \\
\hline Farinha de peixe ${ }^{\mathrm{a}}$ & 20,00 & 0,00 & 5,00 & 10,00 & 15,00 & 20,00 & 660.80 \\
\hline Farinha de vísceras ${ }^{\mathrm{a}}$ & 0,00 & 20,00 & 20,00 & 15,00 & 10,00 & 5,00 & 233.60 \\
\hline Protenose $^{\mathrm{a}}$ & 25,00 & 21,35 & 13,29 & 12,58 & 11,87 & 15,51 & 262.80 \\
\hline Farelo de soja ${ }^{a}$ & 17,71 & 30,00 & 30,00 & 30,00 & 30,00 & 23,40 & 161.60 \\
\hline Milho & 2,88 & 5,08 & 0,00 & 0,00 & 0,00 & 0,00 & 79.20 \\
\hline Farelo de trigo & 14,04 & 15,00 & 15,00 & 15,00 & 15,00 & 11,98 & 70.40 \\
\hline Farinha de trigo & 14,88 & 3,55 & 11,66 & 12,10 & 12,55 & 18,57 & 74.80 \\
\hline Óleo ${ }^{b}$ & 4,00 & 3,00 & 3,12 & 3,52 & 3,93 & 4,00 & 754.40 \\
\hline DL-Metionina (98\%) & 0,23 & 0,42 & 0,39 & 0,36 & 0,32 & 0,28 & $2,583.60$ \\
\hline L-Lisina $(80 \%)$ & 0,15 & 0,50 & 0,44 & 0,34 & 0,23 & 0,15 & $1,932.80$ \\
\hline Mistura mineral e vitamínica ${ }^{c}$ & 0,60 & 0,60 & 0,60 & 0,60 & 0,60 & 0,60 & $4,724.00$ \\
\hline Óxido de cromio & 0,50 & 0,50 & 0,50 & 0,50 & 0,50 & 0,50 & - \\
\hline Custo de formulação (U\$/ton) & 324 & 240 & 252 & 272 & 292 & 312 & - \\
\hline \multicolumn{8}{|l|}{ Composição em nutrientes } \\
\hline Proteína bruta & 46,07 & 46,26 & 46,27 & 45,79 & 45,77 & 45,70 & \\
\hline Extrato etéreo & 8,34 & 8,62 & 8,60 & 8,69 & 8,35 & 8,41 & \\
\hline Fibra bruta & 4,54 & 4,81 & 5,33 & 5,28 & 5,23 & 4,87 & \\
\hline Cinzas & 6,63 & 9,00 & 7,83 & 7,14 & 6,94 & 7,97 & \\
\hline Cálcio & 1,17 & 1,95 & 1,60 & 1,28 & 1,48 & 1,50 & \\
\hline Fósforo & 1,00 & 1,16 & 1,13 & 1,12 & 1,08 & 1,07 & \\
\hline Energia bruta $(\mathrm{kcal} / \mathrm{kg})$ & 4.884 & 4.779 & 4.745 & 4.772 & 4.785 & 4.825 & \\
\hline
\end{tabular}

${ }^{a}$ Composição das fontes protéicas em $\mathrm{g} 100 \mathrm{~g}^{-1}$ na matéria seca: (Farinha de peixe chilena: proteina bruta, 71,52; extrato etéreo, 13,22); (Farinha de vísceras: proteína bruta, 63,27; extrato etéreo, 11,08); (Protenose: proteína bruta, 71,24; extrato etéreo, 3,60); (Farelo de soja: proteína bruta, 51,40; extrato etéreo, 6,71).

${ }^{\mathrm{b}} 2 / 3$ de óleo de soja e 1/3 de óleo de salmão do Atlântico;

' Suplementação/kg de ração: $30 \mathrm{mg}$ de $\mathrm{Mn} ; 120,0 \mathrm{mg}$ de Fe; $150,0 \mathrm{mg}$ de $\mathrm{Zn} ; 17,0 \mathrm{mg}$ de $\mathrm{Cu} ; 0,2 \mathrm{mg}$ de Co; 0,9 mg de I; 8.700 UI de vitamina $A ; 20,0 \mathrm{mg}$ de $B_{6} ; 4.300$ UI de $D_{3} ; 170$ UI de vitamina $E ; 30,0$ $\mathrm{mcg}$ de $\mathrm{B}_{12} ; 10,0 \mathrm{mg}$ de $\mathrm{B}_{1} ; 20,0 \mathrm{mg}$ de $\mathrm{B}_{2} ; 4,3 \mathrm{mg}$ de $\mathrm{K} ; 2,0 \mathrm{mg}$ de Ácido fólico; $1,0 \mathrm{mg}$ de Biotina; 0,6 $\mathrm{mg}$ de Selênio; 40,0 mg de Ácido pantotênico; 40,0 mg de niacina; $1.500,00 \mathrm{mg}$ de Colina; $100,0 \mathrm{mg}$ de Inositol; $300,0 \mathrm{mg}$ de vitamina $\mathrm{C}$ (estabilizada com radicais fosfato). 
Tabela 3. Composição de aminoácidos das dietas experimentais (expressos na matéria seca como porcentagem de cada dieta) ${ }^{1}$

\begin{tabular}{|c|c|c|c|c|c|c|c|}
\hline \multirow[b]{2}{*}{ Aminoácidos } & \multirow[b]{2}{*}{ Exigência ${ }^{2}$} & \multicolumn{6}{|c|}{ Dietas } \\
\hline & & $20 \mathrm{P}: 0 \mathrm{~V}$ & $0 \mathrm{P}: 20 \mathrm{~V}$ & $5 \mathrm{P}: 20 \mathrm{~V}$ & $10 \mathrm{P}: 15 \mathrm{~V}$ & $15 \mathrm{P}: 10 \mathrm{~V}$ & $20 \mathrm{P}: 5 \mathrm{~V}$ \\
\hline \multicolumn{8}{|l|}{ Essenciais (AAE) } \\
\hline Arginina (Arg) & 1,94 & 2,49 & 2,95 & 3,01 & 3,08 & 2,84 & 2,73 \\
\hline Histidina (His) & 0,65 & 0,94 & 0,98 & 0,97 & 0,99 & 0,93 & 0,92 \\
\hline Isoleucina (Ile) & 1,11 & 1,69 & 1,72 & 1,73 & 1,68 & 1,64 & 1,58 \\
\hline Leucina (Leu) & 2,21 & 4,36 & 4,07 & 3,72 & 3,62 & 3,96 & 3,54 \\
\hline Lisina (Lys) & 2,61 & 2,76 & 2,79 & 2,62 & 2,60 & 2,67 & 2,73 \\
\hline Metionina (Met) & 0,89 & 0,90 & 0,84 & 0,82 & 0,84 & 0,89 & 0,86 \\
\hline Fenilalanina (Phe) & 1,19 & 2,03 & 2,09 & 2,01 & 1,99 & 1,84 & 1,88 \\
\hline Treonina (Thr) & 1,32 & 1,50 & 1,60 & 1,58 & 1,63 & 1,50 & 1,51 \\
\hline Triptofano (Trp) & 0,26 & 0,27 & 0,29 & 0,25 & 0,29 & 0,26 & 0,41 \\
\hline Valina (Val) & 1,22 & 1,98 & 2,06 & 2,05 & 2,01 & 1,93 & 1,91 \\
\hline Total Essenciais (AAE) & & 18,92 & 19,39 & 18,76 & 18,73 & 18,46 & 18,07 \\
\hline \multicolumn{8}{|l|}{ Não essenciais (AANE) } \\
\hline Ácido Aspártico (Asp) & 3,03 & 3,42 & 3,84 & 3,84 & 3,94 & 3,63 & 3,54 \\
\hline Ácido Glutâmico (Glu) & 4,32 & 8,11 & 7,16 & 8,01 & 8,02 & 8,39 & 8,59 \\
\hline Alanina (Ala) & 1,79 & 2,99 & 3,06 & 2,84 & 2,84 & 2,61 & 2,73 \\
\hline Cistina (Cys) & 0,28 & 0,46 & 0,54 & 0,54 & 0,55 & 0,50 & 0,50 \\
\hline Glicina (Gly) & 1,83 & 2,22 & 2,66 & 2,71 & 2,77 & 2,58 & 2,51 \\
\hline Serina (Ser) & 1,23 & 2,00 & 2,07 & 1,98 & 2,07 & 1,87 & 1,92 \\
\hline Prolina (Pro) & 1,07 & 3,14 & 3,18 & 3,03 & 3,02 & 2,74 & 2,89 \\
\hline Tirosina (Tyr) & 0,99 & 1,14 & 1,27 & 1,18 & 1,17 & 1,09 & 1,07 \\
\hline Total Não Essenciais (AANE) & & 23,48 & 23,78 & 24,13 & 24,38 & 23,41 & 23,75 \\
\hline Total de Aminoácidos (AA) & & 42,40 & 43,17 & 42,89 & 43,11 & 41,87 & 41,82 \\
\hline
\end{tabular}

${ }^{1}$ Média de três repetições.

${ }^{2}$ Calculado com base no conceito de proteína ideal (Tabela 1) 
Tabela 4. Peso, ganho de peso (GP), consumo alimentar diário (CAD), conversão alimentar (CA), taxa de eficiência protéica (TEP), taxa de crescimento específico (TCE), retenção protéica $(\mathrm{RP})$, retenção energética $(\mathrm{RE})$, composição da carcaça ${ }^{1}$ e coeficiente de digestibilidade aparente (CDA) dos nutrientes nas dietas experimentais (média \pm erro padrão de quatro repetições). Valores seguidos pelo mesmo superscrito não diferem significativamente $\mathrm{P}>0,05$.

\begin{tabular}{|c|c|c|c|c|c|c|}
\hline & \multicolumn{6}{|c|}{ Dietas } \\
\hline & $20 \mathrm{P}: 0 \mathrm{~V}$ & $0 \mathrm{P}: 20 \mathrm{~V}$ & $5 \mathrm{P}: 20 \mathrm{~V}$ & $10 \mathrm{P}: 15 \mathrm{~V}$ & $15 \mathrm{P}: 10 \mathrm{~V}$ & $20 \mathrm{P}: 5 \mathrm{~V}$ \\
\hline \multicolumn{7}{|l|}{ Desempenho } \\
\hline Peso final $(\mathrm{g})$ & $33,68 \pm 4,00^{\mathrm{bc}}$ & $35,68 \pm 3,01^{\mathrm{ab}}$ & $39,11 \pm 2,30^{\mathrm{a}}$ & $33,98 \pm 1,08^{b c}$ & $32,70 \pm 3,31^{b c}$ & $30,10 \pm 1,15^{\mathrm{c}}$ \\
\hline $\mathrm{GP}(\%)$ & $50,20 \pm 7,45^{b}$ & $66,81 \pm 6,55^{\mathrm{ab}}$ & $77,87 \pm 8,66^{\mathrm{a}}$ & $64,39 \pm 9,41^{\mathrm{ab}}$ & $62,37 \pm 8,99^{\mathrm{ab}}$ & $56,80 \pm 6,97^{\mathrm{ab}}$ \\
\hline $\operatorname{CAD}\left(\% \mathrm{dia}^{-1}\right)$ & $7,91 \pm 0,32^{\mathrm{a}}$ & $6,22 \pm 0,21^{\mathrm{ab}}$ & $5,21 \pm 0,29^{\mathrm{b}}$ & $6,75 \pm 0,19^{\mathrm{ab}}$ & $7,49 \pm 0,08^{\mathrm{a}}$ & $7,69 \pm 0,12^{\mathrm{a}}$ \\
\hline $\mathrm{CA}(\mathrm{kg} / \mathrm{kg})$ & $2,37 \pm 0,09^{\mathrm{a}}$ & $1,87 \pm 0,02^{\mathrm{ab}}$ & $1,54 \pm 0,04^{b}$ & $2,02 \pm 0,08^{\mathrm{ab}}$ & $2,24 \pm 0,04^{\mathrm{a}}$ & $2,30 \pm 0,07^{\mathrm{a}}$ \\
\hline $\operatorname{TEP}(\%)$ & $2,61 \pm 0,12$ & $3,32 \pm 0,11$ & $3,63 \pm 0,12$ & $3,09 \pm 0,14$ & $2,92 \pm 0,11$ & $2,53 \pm 0,10$ \\
\hline $\operatorname{TCE}\left(\% \mathrm{dia}^{-1}\right)$ & $0,68 \pm 0,01$ & $0,85 \pm 0,01$ & $0,91 \pm 0,01$ & $0,82 \pm 0,01$ & $0,80 \pm 0,01$ & $0,74 \pm 0,01$ \\
\hline \multicolumn{7}{|l|}{ Retenção de Nutrientes } \\
\hline $\mathrm{RP}(\%)$ & $22,46 \pm 5,04^{\mathrm{ab}}$ & $26,68 \pm 4,01^{\mathrm{ab}}$ & $30,28 \pm 3,37^{\mathrm{a}}$ & $24,03 \pm 2,87^{\mathrm{ab}}$ & $20,18 \pm 3,55^{b}$ & $22,50 \pm 4,28^{\mathrm{ab}}$ \\
\hline $\operatorname{RE}(\%)$ & $12,39 \pm 3,58^{\mathrm{b}}$ & $15,28 \pm 4,56^{\mathrm{ab}}$ & $18,76 \pm 4,13^{a}$ & $13,91 \pm 4,21^{\mathrm{ab}}$ & $16,04 \pm 5,14^{\mathrm{ab}}$ & $14,11 \pm 4,68^{\mathrm{ab}}$ \\
\hline \multicolumn{7}{|l|}{ Composição corporal } \\
\hline Umidade (\%) & $76,78 \pm 0,57^{\mathrm{a}}$ & $74,90 \pm 0,23^{b}$ & $73,58 \pm 0,18^{b}$ & $73,78 \pm 0,55^{\mathrm{b}}$ & $73,20 \pm 0,51^{b}$ & $73,40 \pm 0,34^{b}$ \\
\hline Proteína $(\%)$ & $15,91 \pm 0,04^{\mathrm{c}}$ & $16,10 \pm 0,01^{b c}$ & $16,70 \pm 0,06^{\mathrm{ab}}$ & $16,53 \pm 0,04^{\mathrm{bc}}$ & $16,57 \pm 0,04^{b c}$ & $17,33 \pm 0,09^{\mathrm{a}}$ \\
\hline Extrato etéreo $(\%)$ & $4,38 \pm 0,08^{c}$ & $5,05 \pm 0,08^{\mathrm{bc}}$ & $6,04 \pm 0,09^{\mathrm{a}}$ & $5,72 \pm 0,10^{\mathrm{ab}}$ & $6,01 \pm 0,08^{\mathrm{a}}$ & $5,29 \pm 0,07^{\mathrm{abc}}$ \\
\hline Cinzas $(\%)$ & $2,93 \pm 0,03$ & $3,95 \pm 0,01$ & $3,67 \pm 0,04$ & $3,96 \pm 0,02$ & $4,21 \pm 0,01$ & $3,97 \pm 0,04$ \\
\hline \multicolumn{7}{|l|}{ Digestibilidade (CDA) } \\
\hline Matéria seca (\%) & $62,48 \pm 1,13^{b c}$ & $62,53 \pm 0,75^{b c}$ & $68,02 \pm 0,78^{a}$ & $63,56 \pm 0,98^{b}$ & $61,33 \pm 0,88^{c}$ & $67,57 \pm 0,61^{\mathrm{a}}$ \\
\hline Proteína $(\%)$ & $90,05 \pm 0,99^{\mathrm{a}}$ & $87,75 \pm 1,05^{b}$ & $89,60 \pm 1,12^{\mathrm{ab}}$ & $88,58 \pm 0,87^{\mathrm{ab}}$ & $87,44 \pm 1,09^{b}$ & $89,50 \pm 0,78^{\mathrm{ab}}$ \\
\hline Disponivel (\%) & 41,49 & 40,63 & 41.46 & 40,56 & 40,02 & 40,90 \\
\hline Extrato etéreo (\%) & $77,97 \pm 5,21^{b}$ & $77,69 \pm 4,27^{b}$ & $87,69 \pm 7,40^{\mathrm{a}}$ & $89,18 \pm 6,85^{\mathrm{a}}$ & $80,60 \pm 3,85^{\mathrm{ab}}$ & $86,27 \pm 4,12^{\mathrm{ab}}$ \\
\hline Fibra Bruta (\%) & $63,23 \pm 3,66^{\mathrm{b}}$ & $64,22 \pm 2,74^{b}$ & $75,62 \pm 9,23^{\mathrm{a}}$ & $68,72 \pm 5,74^{\mathrm{ab}}$ & $67,10 \pm 4,01^{\mathrm{ab}}$ & $71,29 \pm 5,11^{\mathrm{ab}}$ \\
\hline Energia (\%) & $69,82 \pm 1,54^{b}$ & $70,40 \pm 1,57^{b}$ & $72,85 \pm 1,32^{\mathrm{a}}$ & $70,39 \pm 4,74^{b}$ & $67,57 \pm 3,07^{\mathrm{c}}$ & $74,17 \pm 0,51^{\mathrm{a}}$ \\
\hline Disponivel ( $\left.k c a l \mathrm{~kg}^{-1}\right)$ & 3.410 & 3.364 & 3.457 & 3.359 & 3.233 & 3.578 \\
\hline Cálcio (\%) & $83,29 \pm 7,24^{\mathrm{ab}}$ & $87,69 \pm 6,25^{a}$ & $83,15 \pm 5,23^{\mathrm{ab}}$ & $78,04 \pm 6,06^{b}$ & $85,19 \pm 4,89^{\mathrm{ab}}$ & $83,81 \pm 7,32^{\mathrm{ab}}$ \\
\hline Fósforo (\%) & $87,47 \pm 6,65$ & $89,48 \pm 4,78$ & $87,43 \pm 6,50$ & $86,30 \pm 2,01$ & $89,10 \pm 6,30$ & $87,49 \pm 3,95$ \\
\hline
\end{tabular}

'base úmida.

O método de preparação das amostras para análise seguiu metodologia da AOAC (2000): digestão ácida em tubos de vidro lacrados sob atmosfera de nitrogênio a $110{ }^{\circ} \mathrm{C}$ com $\mathrm{HCl} 6 \mathrm{~N}$ por 24 horas. Os aminoácidos cistina e metionina foram 
determinados após oxidação com ácido perfórmico antes da hidrólise ácida como descrito por Moore (1963). Após a hidrólise as soluções eram filtradas a vácuo, diluídas a $0,25 \mathrm{M}$ com $\mathrm{HCl} 0,02 \mathrm{~N}$ para ajuste ao $\mathrm{pH} 8,5$ e filtradas em membrana Millipore $(0,45 \mu \mathrm{m})$. Para análise do aminoácido triptofano, foi realizada a hidroxilação de uma amostra com hidróxido de lítio - hidrólise alcalina. Os aminoácidos livres eram separados em um auto analisador de aminoácidos Hitachi modelo L-8500A e os resultados processados em aplicativo específico em computador acoplado.

As determinações dos parâmetros de desempenho e análises avaliados seguem descrições e recomendações de Takeuchi (1988) e Tacon (1990) considerando os seguintes parâmetros:

Ganho de peso - GP (\%)

$\mathrm{GP}=($ peso corporal final - peso corporal inicial $/$ peso corporal inicial $) \times 100$

Consumo alimentar diário - CAD $(\%)$

$\mathrm{CAD}=[$ alimento consumido $\div($ dias de alimentação $\times$ peso corporal $/ 2)] \times 100$

Conversão alimentar - CA $(\mathrm{kg} / \mathrm{kg})$

$\mathrm{CA}=$ alimento ingerido / ganho de peso

Taxa de eficiência protéica - TEP $(\%)$

TEP $(\%)=$ ganho de peso $(\mathrm{g}) /$ proteína na dieta $(\mathrm{g})$

Taxa de crescimento específico - TCE (\%)

$\mathrm{TCE}=[(\ln$ peso corporal final $-\ln$ peso corporal inicial $) /$ dias experimentais $] \times 100$

Retenção protéica - RP (\%)

$\mathrm{RP}=[($ peso corporal final $\times$ proteína corporal final - peso corporal inicial $\times$ proteína corporal inicial) $/$ total de proteína ingerida] $\times 100$

Retenção energética - RE (\%)

$\mathrm{RE}=[$ (peso corporal final $\times$ energia corporal final - peso corporal inicial $\times$ energia corporal inicial) $/$ total de energia ingerida] $\times 100$

Relação víscero-somática - RVS (\%)

RVS $=($ peso das vísceras $*$ peso corporal $) \times 100$

*figado, gônadas, trato gastro intestinal vazio e gordura mesentérica 
Os resultados de desempenho e composição corporal das quatro repetições das diferentes dietas experimentais foram submetidos a análise de variância (ANOVA) e depois submetidos ao teste de comparação de médias Tukey $(\mathrm{P}<0,05)$, pelo aplicativo estatístico SAS (1985).

\subsubsection{Experimento 2 - Digestibilidade}

A determinação dos coeficientes de digestibilidade aparente (CDA) foi feita pelo método indireto utilizando o marcador inerte óxido de cromio $\left(\mathrm{Cr}_{2} \mathrm{O}_{3}\right)$, recomendado para estudos de digestibilidade com peixes (Brisson, 1956; Furukawa \& Tsukahara, 1966; Gaylord \& Gatlin III, 1996; Lied, 1982; NRC, 1993; Shiau \& Chem, 1993; Shiau \& Lin, 1993; Shiau \& Liang, 1995; Shiau \& Shy, 1998). A estimativa da digestibilidade das rações foi baseada nos estudos e procedimentos descritos por De Silva \& Anderson (1995).

Os experimentos foram conduzidos em quatro aquários de digestibilidade cilindro-cônicos de fibra de vidro com capacidade de $200 \mathrm{~L}$, equipados com aerador, aquecedor e termostato, troca de água parcial e recipiente coletor de fezes refrigerado.

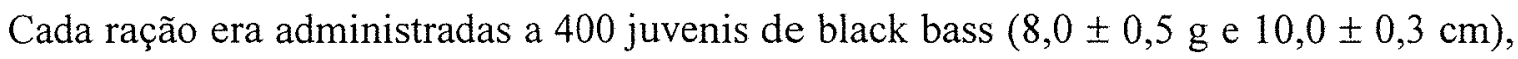
condicionados a aceitar alimento inerte e distribuídos em 4 gaiolas plásticas $(80 \mathrm{~L})$, rígidas, de fundo vazado, mantidas em tanques de polipropileno $(1.000 \mathrm{~L})$. Os peixes foram alimentados ad libitum em 5 refeições diárias entre $8 \mathrm{~h} 00 \mathrm{~m}$ e $18 \mathrm{~h} 00 \mathrm{~m}$ com as rações. Os peixes eram então anestesiados (benzocaína; 0,5\%) e as gaiolas transferidas para os aquários de digestibilidade permanecendo por um período de 10 horas, onde as fezes eram coletadas por sedimentação em recipiente refrigerado, centrifugadas $\left(4^{\circ} \mathrm{C}\right)$, liofilizadas $\left(-55^{\circ} \mathrm{C}\right)$ e armazenadas em super congelador $\left(-10^{\circ} \mathrm{C}\right)$. As análises seguiram os mesmos procedimentos descritos para o Experimento 1.

As determinações dos coeficientes de digestibilidade aparente (CDA - \%) (Maynard \& Loosly, 1969) da matéria seca $\left(\mathrm{CDA}_{\mathrm{MS}}\right)$, nutrientes $\left(\mathrm{CDA}_{\mathrm{N}}\right)$, energia $\left(\mathrm{CDA}_{\mathrm{EB}}\right)$ das dietas experimentais foram calculados segundo Burel et al. (2000), De Silva et al. (2000) e De Silva \& Anderson (1995), como segue: 
$\mathrm{CDA}_{\mathrm{MS}}=100 x\left[1-\left(\frac{\mathrm{Cr}_{2} \mathrm{O}_{3} \text { dieta }}{\mathrm{Cr}_{2} \mathrm{O}_{3} \text { fezes }}\right)\right]$
$\mathrm{CDA}_{\mathrm{N} / \mathrm{EB}}=100 x\left[1-\left(\frac{\mathrm{Cr}_{2} \mathrm{O}_{3} \text { dieta }}{\mathrm{Cr}_{2} \mathrm{O}_{3} \text { fezes }}\right) \times\left(\frac{\text { nutriente ou energia fezes }}{\text { nutriente ou energia dieta }}\right)\right]$

Os valores das quatro repetições dos CDA das diferentes dietas experimentais foram submetidos a análise de variância (ANOVA) e depois submetidos ao teste de comparação de médias Tukey $(\mathrm{P}<0,05)$, pelo aplicativo estatístico SAS (1985).

\subsection{Resultados e Discussão}

Os parâmetros de qualidade da água monitorados nos tanques de alimentação e aquários de digestibilidade permaneceram normais e dentro das condições de conforto para espécie. A composição e análise dos nutrientes das dietas experimentais deste estudo são apresentadas nas Tabelas 2 e 3 . O perfil de aminoácidos essenciais e não essenciais totais permaneceu constante em todas as dietas, sendo que a adição de DLmetionina (98\%) e L-lisina (80\%) foi necessária para o balanceamento dos aminoácidos digestíveis provenientes das fontes protéicas utilizadas. Quanto maiores foram as proporções da farinha de vísceras em substituição a farinha de peixe, menores foram os custos de formulação das dietas (Tabela 2).

O ganho de peso, consumo alimentar diário e conversão alimentar foram diferentes entre os tratamentos $(\mathrm{P}<0,05)$, o mesmo não sendo observado para a taxa de eficiência protéica (TEP) e taxa de crescimento específico (TCE), sendo o tratamento 5FP:20FV a apresentar os valores mais elevados para estes dois parâmetros (Tabela 4). Peixes deste mesmo tratamento apresentaram o maior peso final $(\mathrm{g})$ e melhores índices de ganho de peso percentual (GP), conversão alimentar $(\mathrm{CA})(\mathrm{P}<0,05)$ (Tabela 4). 
Foram observada diferenças $(\mathrm{P}<0,05)$ nas taxas de retenção de nutrientes para proteína e energia. As melhores taxas de retenção protéica $(30,28 \%)$ e energética $(18,76 \%)$ foram observadas para os peixes alimentados com a dieta 5FP:20FV (Tabela 4). Exceto para a matéria mineral, foram detectadas diferenças $(\mathrm{P}<0,05)$ na composição corporal dos peixes submetidos aos vários tratamentos (Tabela 4).

A relação víscero-somática não diferiu entre os tratamentos $(\mathrm{P}>0,05)$, ao contrário do observado em relação aos níveis de lipídio visceral, que apresentaram teores mais elevados nos tratamentos que apresentavam farinha de vísceras na composição da dieta $(\mathrm{P}<0,05)$ (Figura 1). Peixes alimentados com as dietas com maiores proporções de farinha de vísceras na composição apresentaram índices de desempenho iguais ou superiores àqueles que receberam dietas isentas deste ingrediente em relação à retenção de nutrientes e composição corporal $(\mathrm{P}<0,05)$ (Tabela 4).

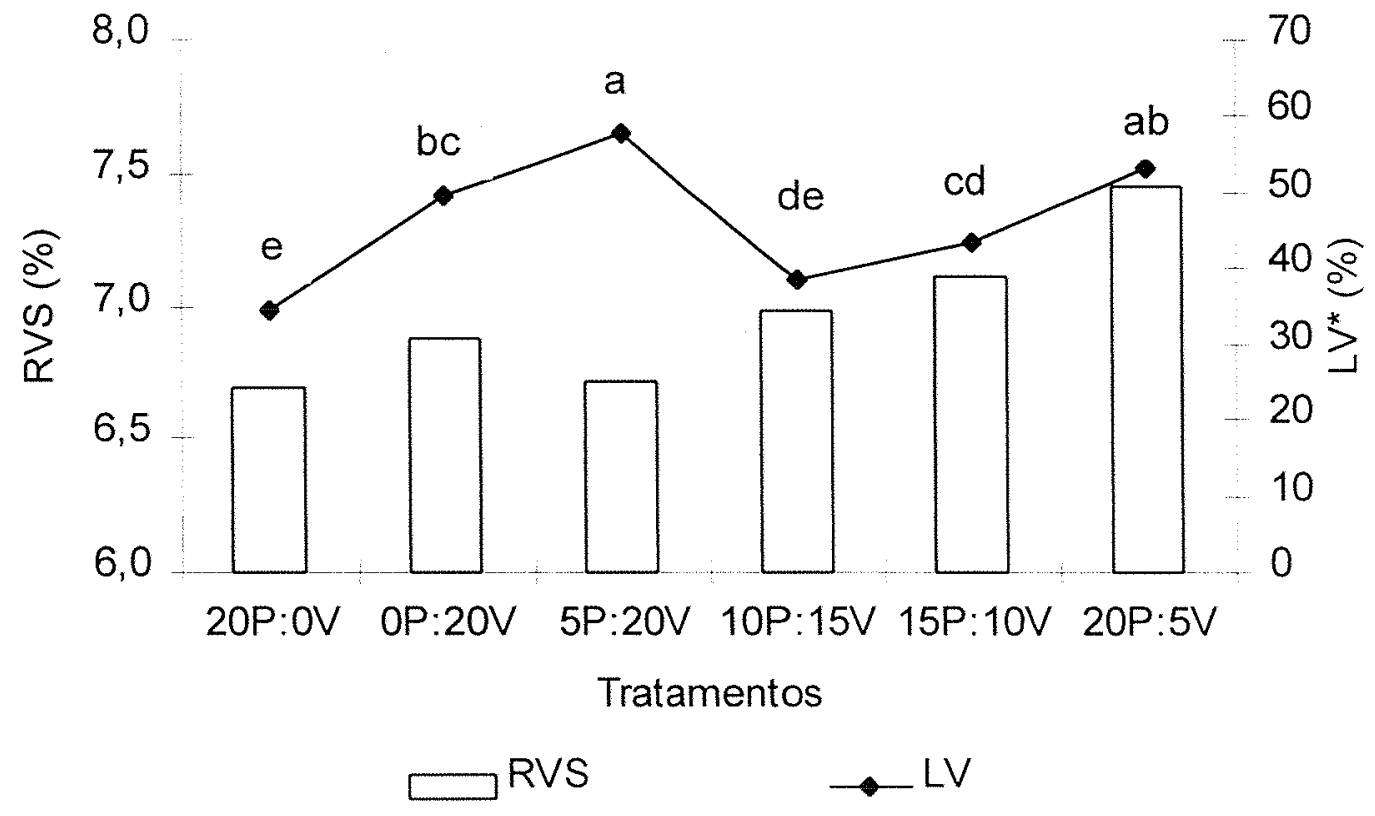

Figura 1 - Relação víscero-somática e níveis de lipídio visceral. Letras iguais não diferem significativamente $\mathrm{P}>0,05$ pelo teste Tukey ( ${ }^{*}$ na matéria seca). 
A Tabela 4 mostra o CDA das dietas experimentais. Com exceção do fósforo, houve diferença significativa $(\mathrm{P}<0,05)$ para os $\mathrm{CDA}$ da matéria seca, proteína, extrato etéreo, fibra bruta, energia e cálcio. Apesar das dietas apresentarem altos teores de fósforo $(\geq 1,00 \%)$ em suas composições, a digestibilidade deste nutriente para o black bass fọi superior a $85 \%$ em todos tratamentos. Uma vez que todos os tratamentos apresentaram alta digestibilidade da proteína, o mesmo deve ser observado em relação ao nitrogênio (Tabela 4).

Os teores de cálcio nas dietas variaram de 1,17 a $1,95 \%$. Os teores mais altos foram observados nas dietas que continham a farinha de vísceras em sua composição, porém a disponibilidade deste nutriente também foi alta. Os maiores valores de CDA para lipídio foram apresentados pelos tratamentos 5FP:20FV e 10FP:15FV (Tabela 4). Os melhores CDA da matéria seca e fibra bruta foram observados nos tratamentos 5FP:20FV e 20FP:5FV (Tabela 4).

Segundo Coyle et al. (2000) a suplementação de lisina e metionina em dietas para black bass podem diminuir a conversão alimentar e melhorar as características da composição corporal para esta espécie. A lisina normalmente é considerado o aminoácido mais limitante em dietas para peixes e sua deficiência normalmente pode reduzir o crescimento e baixar a conversão alimentar (Wilson, 1991). Entretanto, não somente a exigência, como também a digestibilidade dos aminoácidos, são fatores de extrema importância no desempenho e ganho de peso dos peixes. Quando dietas são formuladas com base no conceito de proteína ideal e conteúdos de aminoácidos digestíveis, observa-se que muitas vezes é necessário o aumento nas proporções da farinha de peixe ou inclusão de aminoácidos sintéticos para o balanceamento da dieta.

A metionina é considerado um importante doador de grupamento metil e os níveis de exigência para peixes são apresentados de acordo com as concentrações de cistina na dieta, podendo este último ser substituído por uma porção de quantidades de metionina não exigidos pelo peixe (De Silva \& Anderson, 1995). No presente estudo, foi necessário a suplementação de metionina sintética nos tratamentos que apresentavam maiores inclusões de farinha de vísceras, que se mostrou deficiente neste aminoácido. 
Segundo Lovell (1989b) a inclusão de aminoácidos sintéticos a uma dieta aumenta os custos de produção, mas leva também a um aumento bastante compensador na conversão alimentar. A redução na eficiência da conversão alimentar pode ser um indicativo da deficiência em aminoácidos (Wilson, 1991). Neste experimento, uma vez que as dietas eram isonitrogenadas e isocalóricas, todas diferenças observadas, tanto em relação ao desempenho como à composição corporal dos animais, podem ser atribuídos às diferentes proporções ou combinações de cada ingrediente na dieta.

Os valores médios de ganho de peso dos peixes alimentados com as dietas contendo farinha de vísceras foram superiores ou semelhantes ao da dieta controle (20FP:0FV), que apresentava apenas farinha de peixe em sua composição. Webster et al. (1999) testaram a inclusão de até $28 \%$ da farinha de vísceras isoladamente ou associada à farinha de peixe em dietas experimentais com $40 \%$ de proteína para juvenis de "sunshine bass" (Morone chrysops x M. saxatilis) e observaram os mesmos efeitos de aumento no ganho de peso e melhoras na conversão alimentar. Valores altos de ganho de peso também foram observados para o "Chinook salmon" (Fowler, 1991) e para a enguia européia Anguilla anguilla (Gallagher \& Degani, 1988) alimentados com dietas contendo até $20 \%$ de farinha de vísceras.

A pequena diferença observada no consumo alimentar diário (CAD) nos tratamentos 0FP:20FV e 5FP:20FV pode ter sido causada pela menor palatabilidade das dietas, resultante das menores concentrações de farinha de peixe (Hughes, 1985; McGoogan \& Gatlin III, 1997). Webster et al. (1997) observou que a palatabilidade de dietas para peixes carnívoros influencia muito o consumo alimentar e pode afetar o desempenho dos peixes. Entretanto, apesar da ocorrência de diferenças no consumo diário de alimento, os resultados de ganho de peso não foram afetados no presente estudo (Tabela 4).

A combinação FP/FV trouxe resultados surpreendentes quanto ao ganho de peso e conversão alimentar diária nos tratamentos propostos neste estudo, corroborando relatos de Fowler (1991) que, em estudos com "Chinook salmon" Oncorhynchus tshawytcha, concluiu que a adição de $20 \%$ de farinha de vísceras poderia substituir em até $50 \%$ a farinha de peixes na dieta, mas níveis superiores a $30 \%$ reduziriam o 
crescimento do salmão. Da mesma maneira, Gallagher \& LaDouceur (1995) observou que juvenis de "palmetto bass" alimentados com dietas contendo $12 \%$ de farinha de peixe e $36 \%$ de farinha de vísceras apresentaram ganho de peso semelhantes a peixes alimentados com uma dieta controle contendo $47 \%$ de farinha de peixe.

Webster et al. (1999) trabalhando com "sunshine bass", concluiu que peixes alimentados com dietas contendo $28 \%$ FV e $32 \%$ FS apresentavam índices de desempenho idênticos a peixes alimentados com dietas contendo apenas 30\% FP, mostrando que a combinação da FV/FS poder ser utilizada em substituição a $100 \%$ da farinha de peixe em dietas para peixes carnívoros. Segundo Arruda et al. (2001), seria necessário manter pelo menos uma pequena quantidade de farinha de peixe ou de outro sub-produto, como a silagem de pescado, como atrativa nas dietas para peixes carnívoros, a fim de não prejudicar o consumo da ração e o desempenho dos peixes. McGoogan \& Gatlin III (1997) também sugerem que os atrativos além de melhorarem o desempenho em peixes carnívoros, diminuem o efeito de restrição no consumo causado pela adição do farelo de soja.

As fontes protéicas de origem vegetal freqüentemente apresentam baixos níveis de certos minerais em comparação às fontes protéicas de origem animal; contêm ainda altas quantidades de fósforo na forma de fitato, normalmente indisponivel para os peixes. Apesar de fontes protéicas de origem vegetal serem de menor custo, deve-se observar limites de inclusão destas fontes nas dietas formuladas para peixes, a fim de que as mesmas não apresentem, além da deficiência de alguns aminoácidos, problemas de disponibilidade e absorção de fósforo, aumentando a eliminação deste mineral para o ambiente (Allan et al., 2000).

A inclusão da FV em dietas para peixes pode levar ao aumento do conteúdo de gordura visceral, o que, talvez, possa ser considerado uma desvantagem (Fowler, 1991). No presente estudo, peixes alimentados com as dietas que apresentavam maiores proporções de FV apresentaram maiores conteúdos de gordura visceral, fato que pode ser atribuído à alta digestibilidade dos lipídios saturados presentes na farinha de vísceras (Fowler, 1991). 


\subsection{Conclusões}

À luz dos resultados relatados, pode-se recomendar a inclusão de $20 \%$ de farinha de vísceras na produção de rações mais econômicas e nutricionalmente completas para indústria de rações para peixes carnívoros. A manutenção de um conteúdo mínimo de $5 \%$ de farinha de peixe nas rações garantiu a otimização do desempenho do black bass nas condições experimentais. 


\section{CONCLUSÕES GERAIS}

O perfil de aminoácidos no tecido muscular e na carcaça do black bass é, aparentemente, um índice muito melhor do que o padrão das ovas para determinação das exigências nutricionais em aminoácidos pela espécie. As pequenas diferenças encontradas na composição de aminoácidos da carcaça do black bass com peso vivo variando entre 0,53 e $844,0 \mathrm{~g}$, pode servir como uma indicação de que as exigências em aminoácidos da espécie, quando expressas como porcentagem da proteína dietética, diferem com o aumento do tamanho do peixe. As relações entre aminoácidos apresentadas neste estudo indicam que as exigências em aminoácidos do black bass e do surubim, espécies ictiófagas, não apresentam maiores variações, ao contrário da tilápia, espécie herbívora; e estas poderiam ser utilizadas como uma ferramenta de auxílio no ajuste do balanceamento de aminoácidos em formulações de rações para estas espécies.

Os resultados dos ensaios demonstram ainda a necessidade e importância da determinação da digestibilidade dos ingredientes protéicos, visando maior precisão na formulação de rações de custo mínimo para peixes carnívoros. Em adição, mostram que a disponibilidade dos aminoácidos dos ingredientes protéicos é bastante variável, devido principalmente a qualidade destas fontes protéicas. Pode-se concluir ainda que a o farelo de soja e o farelo de glúten podem ser utilizados como substitutos parciais das fontes protéicas de origem animal nas rações formuladas para o black bass. A farinha de vísceras pode ser considerada um boa opção como fonte protéica animal em rações de peixes carnívoros, uma vez que possui boa digestibilidade, padrão de aminoácidos adequado e alta disponibilidade do fósforo.

À luz dos resultados relatados, pode-se recomendar a inclusão de $20 \%$ de farinha de vísceras na produção de rações mais econômicas e nutricionalmente 
completas para indústria de rações para peixes carnívoros. A manutenção de um conteúdo mínimo de $5 \%$ de farinha de peixe nas rações garantiu a otimização do desempenho do black bass nas condições experimentais. 


\section{REFERÊNCIAS BIBLIOGRÁFICAS}

AKENSON, W.R.; STAHMAN, M.A. A pepsin pancreatic digest index of protein quality evaluation. The Journal of Nutrition, v.83, v.3, p.257-261, 1964.

AKIYAMA, T.; OOHARA, I.; YAMAMOTO, T. Comparison of essential amino acid requirements with A / E ratio among fish species. Fisheries Science, v.63, n.6, p. 963-970, 1997.

AKSNES, A. Growth, feed efficiency and slaughter quality of Atlantic salmon, Salmo salar, L., given feeds with different ratios of carbohydrate and protein. Aquaculture Nutrition, v.1, p.241-248, 1995.

ALEXIS, M.N.; NENGAS, I.; DAVIES, S.J.; PETICHAKIS, G. Investigation to determine digestibility coefficients of various raw materials in diets for gilthead sea bream, Sparus auratus L. Aquaculture Research, v.26, p.185-194, 1995.

ALSTED, N.S. Studies on the reduction of discharges from fish farms by modification of the diet. In: INTERNATIONAL SYMPOSIUM ON FEEDING FISH IN OUR WATER: NUTRITIONAL STRATEGIES IN MANEGEMENT OF AQUACUlTURE WASTE, Ontario, 1991. Proceedings. Ontario, 1991. p. $77-90$.

ALVAREZ, M.J.; LÓPEZ-BOTE, C.J.; DIEZ, A.; CORRAZE, G.; ARZEL, J.; DIAS, J.; KAUSHIK, S.J.; BAUTISTA, J.M. The partial substitution of digestible protein with gelatinized starch as an energy source reduces susceptibility to lipid oxidation in rainbow trout (Oncorhynchus mykiss) and sea bass (Dicentrarchus labrax) muscle Journal of Animal Science, v.77, p.33223329, 1999. 
ALLAN, G.L.; PARKINSON, S.; BOOTH M.A.; STONE, D.A.J.; ROWLAND, S.J.; FRANCES, J.; WARNER-SMITH, R. Replacement of fish meal in diets for Australian silver perch, Bidyanus bidyanus: I. digestibility of alternative ingredients. Aquaculture, v.186, p.293-310, 2000.

ALLIOT, E.; PASTOREAUDT, A.; PELAEZ HUDLET, J.; MÉTAILLER, R. Utilisation des farines végétales et des levedures cultivées sur alcanes pour l'alimentation du bar (Dicentrarchus labrax). In: WORLD SYMPOSIUM FINFISH NUTRITION FISHFEED TECHNOLOGY, Hambur, 1978. Proceedings. Berlin: Heenemann, 1978. v.2, p. 229-238.

ANDERSON, J.S.; LALL, S.P.; ANDERSON, D.M.; CHANDRASOMA, J. Apparent and true availability of amino acids from common feed ingredients for Atlantic salmon (Salmo salar) reared in sea water. Aquaculture, v.108, p.111124, 1992.

ANDERSON, R.J.; KIENHOLZ, E.W.; FLICKINGER, S.A. Protein requirements of small mouth bass and largemouth bass. Journal of Fish Nutrition, v.111, p.1085-1097, 1981.

ARAI, S. A purified test diet for Coho salmon, Oncorhynchus kisutch, fry. The Journal of the Nippon Suisan Gakkaishi, v. 47, p. 547-550, 1981.

ARAI, S.; OGATA, H. Quantitative amino acid requirements of fingerling Coho salmon. In: US-JAPAN SYMPOSIUM ON AQUACULTURE NUTRITION, 20. Japan, 1993. Proceedings. Newport, OR: UJNR Department of Commerce, 1993. p.19-28.

ARNESEN, P.; BRATTAS, L.E.; OLLI, J.; KROGDAHL, A. Soybean carbohydrates appear to restrict the utilization of nutrients by Atlantic salmon (Salmo salar L.). In: TAKEDA, M.; WATANABE, T. The Current Status of Fish Nutrition in Aquaculture. Tokyo: Tokyo University Fisheries, 1989. p. $273-280$. 
ARRUDA, L.F.; BORGHESI, R.; OETTERER, M.; PORTZ, L. Silagem de pescado. Panorama da Aqüicultura, v.11, n.65, p. 34-36, 2001.

ASSOCIATION OF OFFICIAL ANALYTICAL CHEMISTS, Methods of Analysis, 14. ed. Washington, 1984. p.152-160:

ASSOCIATION OF OFFICIAL ANALYTICAL CHEMISTS, Methods of Analysis, 17. ed., Maryland, 2000. v.1, p.5-20.

ATKINSON, J.L.; HILTON J.W.; SLINGER, S.J. Evaluation of acid-insoluble ash as an indicator of feed digestibility in rainbow trout (Salmo gairdneri). Canadian Journal Fishery Aquatic Science, v.41, p.1384-1386, 1984.

AUSTIN, B.; AL-ZAHRANI, A.M.J. The effect of antimicrobial compounds on the gastrointestinal microflora of rainbow trout, Salmo gairdneri Richardson. Journal of Fish Biology, v.33, p.1-14, 1998.

AUSTRENG, E. Digestibility determination in fish using chromic oxide marking and analysis of contents from different segments of gastro-intestinal tract. Aquaculture, v.13, p.265-272, 1978.

AUSTRENG, E.; SKREDE, A.; ELDEGARD, A. Effect of dietary fat source on the digestibility of fat and fatty acids in rainbow trout and mink. Acta Agricola Scandinavian, v.29, p.119-126, 1979.

BAKER, D.H. Partitioning of nutrients for growth and other metabolic functions: efficiency and priority considerations. Journal of Poultry Science, v.70, p.1797$1805,1991$.

BAKER, D.H.; HAN, Y. Ideal amino acid profile for chicks during the first three weeks post hatching. Journal of Poultry Science, v.73, p.1441-1447, 1994a.

BAKER, D.H.; HAN, Y. Ideal protein and amino acid requirements of broiler chicks. In: DEGUSSA TECHNICAL SYMPOSIUM \& CALIFORNIA 
NUTRITION CONFERENCE, Fresno, 1994. Proceedings. California: Fresno, 1994b. p.21-24.

BAKKE-McKELLEP, A.M.; NORDRUM, S.; KROGDAHL, Å.; BUDDINGTON, R.K. Absorption of glucose, amino acid, and peptides by intestines of Atlantic salmon (Salmo salar L.). Fish Physiology and Biochemistry, v.22, p.33-44, 2000 .

BALARIN, J.D.; HALLER, R.D. Requirements of Nile tilapia (Oreochromis niloticus). In: MUIR, J.F.; ROBERTS, R.J. (Ed.) Recent Advances in Aquaculture. London: Croom Helm, 1982. p.265-356.

BELAL, I.E.H.; ASSEM, H. Substitution of soybean meal and oil for fish meal in practical diets fed to channel catfish, Ictalurus punctatus (Rafinesque): effects on body composition. Aquaculture Research, v.26, p.141-145, 1995.

BERGOT, F.; BREQUE J. Digestibility of starch by rainbow trout: effects of the physical state of starch and of the intake level. Aquaculture, v.34, p.213-222, 1983.

BLINCOE, C.; THEISEN, M.O.; STODDARD-GILBERT, K. Sample oxidation procedures for the determination of chromium and nickel in biological material. Communications in Soil Science and Plant Analysis, v.18, p.687-692, 1987.

BOONYARATPALIN, M. ; SURANEIRANAT, P. ; TUNPIBAL, T. Replacement of fish meal with various types of soybean products in diets for the Asian sea bass, Lates calcarifer. Aquaculture. v. 161, p.67-78, 1998.

BORLONGAN, I.G.; COLOSO, R.M. Requirements of juvenile milkfish (Chanos chanos Forsskal) for essential amino acids. Journal of Nutrition, v.123, p.125$132,1993$.

BOWEN, S.H. Digestion and assimilation of periphytical detrital aggregate by Tilapia mossambica. Transactions of the American Fisheries Society, v.110, p.239-245, 1981. 
BRANSDEN, M.P.; CARTER, C.G. Effect of processing soybean meal on the apparent digestibility of practical diets for the greenback flounder Rhombosolea tapirina (Günther). Aquaculture Research, v.30, p.719-723, 1999.

BRECKA, B.J.; WAHL, D.H.; HOOE, M.L. Growth, survival and body composition of largemouth bass fed various commercial diets and protein concentrations. The Progressive Fish Culturist, v.58, p.104-110, 1996.

BRISSON, G.J. On the routine determination of chromic oxide in feces. Canadian Journal of Agriculture Science, v.36, p.210-212, 1956.

BROWN, B.P.; STRANGE, R.J.; ROBBINS, K.R. Protein digestibility coefficients for yearling channel catfish fed high protein feedstuffs. The Progressive Fish Culturist, v.54, p.44-49, 1985.

BROWN, M.L.; NEMATIPOUR, G.R.; GATLIN, D.M. Dietary protein requirement of juvenile sunshine bass at different salinities. The Progressive of Fish Culturist, v.54, p.148-156, 1992.

BROWN, P.B. Using whole-body amino acid patterns and quantitative requirements to rapidly develop diets for new species such as striped bass (Morone saxatilis). Journal of Applied Ichthyology, v.11, p.342-346, 1995.

BRUCKENTAL, I. The ratio of naturally occurring ${ }^{13} \mathrm{C}$ and ${ }^{12} \mathrm{C}$ isotopes in sheep diet and faces as a measurement for direct determination of Lucerne hay and maize grain digestibilities in mixed diets. Journal Agriculture Science, v.104, p.271-274, 1985.

BUENTELLO, J.A.; GATLIN III, D.M. The dietary arginine requirement of channel catfish (Ictalurus punctatus) is influenced by endogenous synthesis of arginine from glutamic acid. Aquaculture, v.188, p.311-321, 2000.

BUREAU, D.P.; HARRIS, A.M.; CHO, C.Y. Apparent digestibility of rendered animal protein ingredients for rainbow trout (Oncorhynchus mykiss). Aquaculture, v.180, p.345-358, 1999. 
BUREL, C.; BOUJARD, T.; TULLI, F.; KAUSHIK, S.J. Digestibility of extruded peas, extruded lupin, and rapeseed meal in rainbow trout (Oncorhynchus mykiss) and turbot (Psetta maxima). Aquaculture, v.188, p.285-298, 2000.

CARNEIRO, P.C.F.; CYRINO, J.E.P.; CASTAGNOLlI, N. Produção da tilápia vermelha da Flórida em tanques-rede. Scientia Agricola, v.56, n.3, p.673-679, 1999.

CARTER, C.G.; HAULER, R.C. Fish meal replacement by plant meals in extruded feeds for Atlantic salmon, Salmo salar L. Aquaculture, v.185, p.299-311, 2000.

CARTER, C.G.; OWEN, S.F.; HE-Z, Y.; WATT, P.W. SCRIMGEOUR, C.; HOULIHAN, D.F.; RENNIE, M.J. Determination of protein synthesis in rainbow trout, Oncorhynchus mykiss, using a stable isotope. Journal of Experimental Biology, v.189, p.279-284, 1994.

CARVAlHo FILHO. Ah, vida dura: A febre dos pesque-pagues. Panorama da Aquicultura, v.39, n.7, p.20-21, 1997.

CHANCE, R.E.; MERTZ, E.T.; HALVER, J.E. Nutrition of salmonid fishes, XII. Isoleucine, leucine, valine and phenylalanine requirements of Chinook salmon and interrelations between isoleucine and leucine for growth.. Journal of Nutrition, v.83, p.177-185, 1964.

CHO C.Y.; COWEY, C.B.; WATANABE T. Finfish Nutrition in Asia. Methodological approaches to research and development. Canada: International Development Research Center, 1985. 132p.

CHO, C.Y. Effects of dietary protein and lipid levels on energy metabolism of rainbow trout (Salmo gairdneri). In: EKERN, A.; SUNDSTL, F. Energy Metabolism of Farm animals. London: European Association for Animal Production, 1982. p.175-183. 
$\mathrm{CHO}, \mathrm{C} . \mathrm{Y}$. Feeding for rainbow trout and other salmonids, with reference to current estimates of energy and protein requirement. Aquaculture, v.100, p.107-123, 1992.

CHO, C.Y. Fish nutrition, feeds, and feeding: with special emphasis on salmonid aquaculture. Food Reviews International, v.6, p.333-357, 1990.

CHO, C.Y.; SLINGER, S.J. Apparent digestibility measurements in feedstuffs for rainbow trout. In: HALVER, J.E; TIEWS, K. Finfish Nutrition and Fish Feed Technology. Berlin: Heinemann, 1979. p.239-247.

CHO, C.Y; KAUSHIK, S.J. Nutrition energetic in fish: energy and protein utilization in rainbow trout - Salmo gairdneri. World Reviews Nutrition Diets, v.61, p.132-172, 1990.

CHOUBERT, G.; DE LA NOÜE, J.; LUQUET, P. Continuous quantitative automatic collector for fish feces. The Progressive Fish Culturist, v.41, p.64$67,1979$.

CHOUBERT, G.; DE LA NOÜE, J.; LUQUET, P. Digestibility in fish: Improved device for the automatic collection of feces. Aquaculture, v.29, p.185-189, 1982.

CHUNG, T.K.; BAKER, D.H. Ideal amino acid pattern for 10-kilogram pigs. Journal of Animal Science, v. 70, p.3102-3111, 1992.

COLE, D.J.A. Amino acid nutrition of the pig. In: HARESING, W.; LEWIS, D. (Ed.) Recent Advances in Animal Nutrition. London: Butterwoth, 1978. p.5972.

COLIN, B.; COWEY, C.B.; YOUNG, D.C.; CHO, C. Nutrition requirement of fish. Proceedings of the Nutrition Society, v.52, p.417-426, 1993.

COLT, J.; MONTGOMERY, J.M. Aquaculture production systems. Journal of Animal Science, v.69, p.4183 - 4192. 1991. 
CONTRERAS G., E. A new approach to the evaluation of fish meal quality by reaction with 2, 4, 6-trinitrobenzenesulfonic acid. In: CHANG, Y.K; WANG, S.S. Advances in Extrusion Technology. Lancaster: Technomic Publ., 1999. p.179-189.

COWEY, C.B. Amino acids requirement of fish: a critical appraisal of present values. Aquaculture,, v.124, p.1-11, 1994.

COWEY, C.B.; LUQUET, P. Physiological basis of protein requirements of fishes. Critical analysis of allowances. In: INTERNATIONAL SYMPOSIUM OF PROTEIN METABOLISM AND NUTRITION, 4., Paris, 1983. Proceedings France: INRA, 1983. p. 363-384.

COWEY, C.B.; LUQUET, P. Physiological basis of protein requirements of fishes. Critical analysis of allowances. In: PION, R.; ARNAL, M.; BONIN, D. (Ed.) Protein Metabolism and Nutrition. Paris: I.N.R.A., 1983. v.1, p.365-384.

COWEY, C.B.; TACON, A.G.J. Fish nutrition-relevance to invertebrates. In: INTERNATIONAL CONFERENCE ON AQUACULTURE NUTRITION: BIOCHEMICAL AND PHYSIOLOGICAL APPROACHES TO SHELLFISH NUTRITION, 2., Baton Rouge, 1983. Proceedings. Baton Rouge: Louisiana State University, Division of Continuing Education, 1983 . p.13-30.

COYLE, S.D.; TIDWELL, J.H.; WEBSTER, C.D. Response of largemouth bass Micropterus salmoides to dietary supplementation of lysine, methionine, and highly unsaturated fatty acids. Journal of World Aquaculture Society, v.31, n.1, p.89-95, 2000.

CRAIG, S.R.; GATLIN III, D.M. Dietary lysine requirement of juvenile red drum Sciaenops ocellatus. Journal of the World Aquaculture Society, v.23, n.2, p.133-137, 1992.

CYRINO, J.E.P. Condicionamento alimentar e exigências nutricionais de espécies carnívoras - Desenvolvimento de uma linha de pesquisa. Piracicaba, 2000. 
200p. Tese (Livre docência) - Escola Superior de Agricultura "Luiz de Queiroz", Universidade de São Paulo.

DABROWSKY, K.; DABROWSKA, H. Digestion of protein by rainbow trout and absorption of amino acids within the alimentary tract. Comparative Biochemistry Physiology, v.69a, p.99-111, 1981.

DANIELS, W.H.; ROBINSON, E.H. Protein and energy requirement of red drum. Aquaculture, v.53, p.232-243, 1986.

DAVIDEK, J.; VELISEK, J.; POKORNY, J. Proteins, peptides and amino acids. In: Chemical Changes During Food Processing. Amsterdam: Elsevier, 1990, p. 151.

DE LA NOÜE, J.; CHOUBERT, G. Digestibility in rainbow trout: Comparison of the direct and indirect methods of measurement. The Progressive Fish Culturist, v.48, p. 190-195, 1986.

De SILVA, S.S.; ANDERSON, T.A. Fish Nutrition in Aquaculture. London: Chapman \& Hall, 1995. 319p.

De SILVA, S.S.; DENG, D.F.; RAJENDRAM, V. Digestibility in goldfish fed diets with and without chromic oxide and exposed to sublethal concentrations of cadmium. Aquaculture Nutrition, v.3, p.109-114, 1997.

De SILVA, S.S.; GUNASEKERA, R.M.; GOOLEY, G. Digestibility and amino acid availability of three protein-rich ingredient-incorporated diets by Murray cod Maccullochella peelii peelii (Mitchell) and the Australian shortfin eel Anguilla australis Richardson. Aquaculture Research, v.31, p.195-205, 2000.

De SILVA, S.S.; PERERA, M.K. Digestibility of an aquatic macrophyte by the cichlid Etroplus suratersis (Bloch) with observations on the relative merits of three indigenous markers and daily changes in protein digestibility. Journal of Fish Biology, v.23, p.675-684, 1983. 
DEGANI, G. Effect of replacement of fish and chicken meal by soybean meal in a purified diet on growth and body composition of juvenile European eel Anguilla anguilla. Indian Journal of Fisheries, v.34, p.213-217, 1987.

DeLONG, D.C.; HALVER, J.E.; MERTZ, E.T. Nutrition of salmonid fishes, X. quantitative threonine requirements of Chinook salmon at two water temperatures. Journal of Nutrition, v.76, p.174-178, 1962.

DeLONG, D.C.; HALVER, J.E; MERTZ, E.T. Nutrition of salmonid fishes VI. Protein requirement of Chinook salmon at two water temperatures. Journal of Nutrition, v.65, p.589-599, 1958.

DIANA; J.S.; SZYPER, J.P.; BATTERSON, T.R.; BOYD, C.E.; PIEDRAHITA, R.H. Water quality in ponds. In: EGNA, H.S.; BOYD, C.E. (Ed.). Dynamics of Pond Aquaculture. Boca Ratón: CRC Press, Inc., 1997. p.53-71.

EINEN, O. ASGÅRD, T.; HOLMEFJORD, I.; TALBOT, C. Auditing nutrient discharges from fish farms: theoretical and practical considerations. Aquaculture Research, v.26, p.701-713, 1995.

ELANGOVAN, A., SHIM, K.F. The influence of replacing fish meal partially in the diet with soybean meal on growth and body composition of juvenile tin foil barb (Barbodes altus). Aquaculture, v. 189, p.133-144, 2000.

FANGBENRO, O.A. Validation of the essential amino acid requirements of Nile tilapia, Oreochromis niloticus (Linnaeus 1758), assessed by the ideal protein concept. In: INTERNATIONAL SYMPOSIUM ON TILAPIA AQUACUlTURE, 5., Rio de Janeiro, 2000. Proceedings. Rio de Janeiro: Panorama da Aqüicultura, 2000. v.1, p.154-156.

FISH AND WILDLIFE SERVICE OF THE UNITED STATES DEPARTAMENT OF THE INTERIOR. National Survey of Fishing, Hunting, and Wildlifeassociated Recreation. Washington, DC: U.S. Department of Interior/Fish and Wildlife Service, 16p., 1992. 
FOOD AND AGRICULTURE ORGANIZATION. Aquaculture production statistics. FAO Fisheries Circular No. 815, Revision 9. Rome: FAO Fisheries Department. 1997.

FOWLER, L.G. Poultry by-product meal as a dietary protein source in full Chinook salmon diets. Aquaculture, v.99, p.309-321, 1991.

FURUKAWA, A.; TSUKAHARA, H. On the acid digestion method for the determination of chromic oxide as an index substance in the study of digestibility of fish feed. Bulletin of the Japanese Society of Scientific Fisheries, v.32, p.502-506, 1966.

FURUYA, W.M. Digestibilidade aparente de aminoácidos e substituição da proteína da farinha de peixe pela do farelo de soja com base em proteína ideal em rações para a tilápia do Nilo (Oreochromis niloticus). Botucatu, 2000. 69p. Tese (Doutorado) - Faculdade de Medicina Veterinária e Zootecnia, Universidade Estadual Paulista "Júlio de Mesquita Filho".

GALLAGHER, M.L.; DEGANI, G. Poultry meal and poultry oil as sources of protein and lipid in the diet of European eels (Anguilla anguilla). Aquaculture, v.73, p.177-187, 1988 .

GALLAGHER, M.L; LaDOUCEUR, M. The use of blood meal and poultry products as partial replacements for fish meal in diets for juvenile palmetto bass (Morone saxatilis x M. chrysops). Journal of Applied Aquaculture, v.5, n.3, p.57-65, 1995.

GALLEGUILLOS, M.; ROMO, D. Un parámetro de calidad para harina de pescado. In: INTERNATIONAL SYMPOSIUM ON FISH NUTRITION AND FEEDING, 5., Santiago, 1992. Anais. Santiago.61p.

GATLIN III, D.M. Nutrient requirement of fish and crustaceans with application to diets development in aquaculture. In: CHANG, Y.K; WANG, S.S. Advances in Extrusion Technology. Lancaster: Technomic Publishing Co., 1999a. p.29-33. 
GAYLORD, T.G.; GATLIN, D.M. III. Determination of digestibility coefficients of various feedstuffs for red drum (Sciaenops ocellatus). Aquaculture, v.139, p.303-314, 1996.

GIRI, S.S., SAHOO, S.K., SAHU A.K., MUKHOPADHYAY, P.K. Growth, feed utilization and carcass composition of catfish Clarias batrachus (Linn.) fingerlings fed on dried fish and chicken viscera incorporated diets. Aquaculture Research.. v. 30, p. 767-771, 2000.

GODOY, M.P. Observações sobre a adaptação do "black bass" (Micropterus salmoides) em Pirassununga, Estado de São Paulo. Revista Brasileira de Biologia, v.14, n.2, p.32-38, 1954.

GOMES, E.F. ; REMA, P. ; KAUSHISK, S. J. Replacement of fish meal by plant proteins in the diet of rainbow trout (Oncorhynchus mykiss): digestibility and performance. Aquaculture. v. 130, p. 177-186, 1995.

GRIFFIN, M.E.; BROWN, P.B.; GRANT, A.L. The dietary lysine requirement of juvenile hybrid striped bass. Journal of Nutrition, v. 122, p.1332-1337, 1992.

HAJEN, W.E.; HIGGS, D.A.; BEAMES, R.M.; DOSANJH, B.S. Digestibility of various foodstuffs by post-juvenile Chinook salmon (Oncorhychus tshawytscha) in sea water. 2. Measurement of digestibility. Aquaculture, v.112, p.333-348, 1993a.

HAJEN, W.E.; HIGGS, D.A.; BEAMES, R.M.; DOSANJH, B.S. Digestibility of various feedstuffs by pos-juvenile Chinook salmon (Oncorhychus tshawytscha) in sea water. 1. Validation of technique. Aquaculture, v.112, p.321-332, 1993b.

HALVER, J.E. Fish Nutrition. San Diego: Academic Press, 1989. 256p.

HALVER, J.E. Nutrition of salmonid fishes, IV. An amino acid test diet for Chinook salmon. Journal of Nutrition, v.62, p. 245-254, 1957. 
HEINEN, J.M. Light control for fish tanks. The Progressive Fish Culturist, v.60, p.323-330, 1998.

HENKEN, A.M.; KLEINGELD, D.W.; TIJSSEN, P.A.T. The effect of feeding level on apparent digestibility of dietary dry matter, crude protein and gross energy in the African catfish Clarias gariepinus (Burchell, 1822). Aquaculture, v.51, p.1$11,1985$.

HILTON, J.W.; CHO, C.Y.; SLINGER, S.J. Effect of extrusion processing and steam pelleting diets on pellet durability, pellet water absorption, and the physiological response of rainbow trout (Salmo gairdneri R.). Aquaculture. v.25, p.185-194, 1981.

HUGHES, S.G. Single-feeding response of Chinook salmon fry to potential feed intake modifiers. Progressive Fish Culturist, v.55, p.40-42, 1985.

HUGHES, S.G.; RUMSEY, G.L.; NESHEIM, M.C. Branched-chain amino acid aminotransferase activity in the tissue of lake trout (Salvelinus namaycush). Comparative Biochemistry Physiology B. v.76, n.3, p.429-431, 1983.

HUNG, S.S.O.; BERGE, G.M.; STOREBAKKEN, T. Growth and digestibility effects of soya lecithin and choline on juvenile Atlantic salmon. Aquaculture Nutrition, v.3, p.141-144, 1997.

INABA, D.; OGINO, C.; TAKAMATSU, S.; SUGAMO, S.; HATA, H. Digestibility of dietary components in fish. I. Digestibility of dietary proteins in rainbow trout. Bulletin of the Japanese Society of Scientific Fisheries, v.28, p.367-371, 1962.

JARAMILLO, M.P.S. Nutrientes esenciales. In: JARAMILLO, M.P.S.; GÓMEZ, H.R.; DAZA, P.V. (Ed.) Fundamentos de Nutrición y Alimentación en Acuicultura. Bogotá; I.N.P.A., Instituto Nacional de Pesca y Acuicultura, 1996. p.53-63.

JOBLING, M. Fish Bioenergetics. London: Chapman \& Hall, 1994. 309p. 
JOHNSEN, F; WANDSVIK, A. The impact of high energy diets on pollution control in the fish farming industry. In: INTERNATIONAL SYMPOSIUM ON FEEDING FISH IN OUR WATER: NUTRITIONAL STRATEGIES IN MANAGEMENT OF AQUACUlTURE WASTE, Ontario, 1991. Proceedings. Ontario, 1991. p.51-64.

KABIR, N.M.J.; WEE, K.L.; MAGUIRE, G. Estimation of apparent digestibility coefficients in rainbow trout (Oncorhynchus mikyss) using different markers: 1. Validation of microtracer F-Ni as marker. Aquaculture, v.167, p.259-272, 1998.

KAUSHICK, S.J.; CRAVEDI, J.P.; LALLES, J.P.; SUMPTER, J.; FAUCONNEAU, B.; LAROCHE, M. Partial or total replacement of fish meal by soybean protein on growth, protein utilization, potential estrogenic or antigenic effects, cholesterolemia and flesh quality in rainbow trout, Oncorhynchus mykiss. Aquaculture. v.133, p.257-274, 1995.

KAUSHIK, S. Effect of salinity for rainbow trout on arginine deficiency. In: HALVER, J.E.; TIEWS, K. (Ed.) Finfish Nutrition and Fishfeed Technology. Berlin; Heemann, 1979. v.1, p.197-207.

KEEMBIYEHETTY, C.N.; GATLIN III, D.M. Total sulfur amino acid requirement of juvenile hybrid striped bass (Morone chrysops x M. saxatilis). Aquaculture, v.110, p.331-339, 1993.

KETOLA, H.G. Amino acid nutrition of fishes: requirements and supplementation of diets. Comparative Biochemistry and Physiology, v.73B, p.17-24, 1982.

KETOLA, H.G. Requirement for dietary lysine and arginine by fry of rainbow trout. Journal of Animal Science, v.56, n.1, p.103-107, 1983a.

KETOLA, H.G. Requirement for dietary lysine and arginine by fry of rainbow trout Salmo gairdneri. Journal of Animal Science, v.56, n.1, p.101-107, 1983b. 
KIAERSKOW, J. Production and economics of "low pollutions diets" for the aquaculture industry. In: INTERNATIONAL SYMPOSIUM ON FEEDING FISH IN OUR WATER: NUTRITIONAL STRATEGIES IN MANAGEMENT OF AQUACUlTURE WASTE, Ontario, 1991. Proceedings. Ontario, 1991. p. $65-76$.

KIKUCHI,K. Partial replacement of fish meal with corn gluten meal in diets for Japanese flounder Paralichthys olivaceus. Journal of the World Aquaculture Society. v. 30, p.357-363, 1999.

KIM, J.D.; LALL, S.P. Amino acid composition of whole body tissue of Atlantic halibut (Hippoglossus hippoglossus), yellowtail flounder (Pleuronectes ferruginea) and Japanese flounder (Paralichthys olivaceus). Aquaculture, v.187, p.367-373, 2000.

KUBITZA, F. Intensive culture of largemouth bass Micropterus salmoides: production of advanced juveniles and food-size fish. Alabama, 1995. 145p. Thesis (Ph.D.) - Auburn University.

KUBITZA, F.; LOVSHIN, L.L. Pond production of pellet-fed advanced juvenile and food-size largemouth bass. Aquaculture, v.149, p.253-262, 1997.

KUBITZA, F.; LOVSHIN, L.L.; LOVELL, R.T. Identification of feed enhancers for juvenile largemouth bass Micropterus salmoides. Aquaculture, v.148, p.191$200,1997$.

LEYVA, G.A. Avances en el cultivo comercial de lobina (Micropterus salmoides). Panorama Acuicola, v.3, n.5, p.10, 1998.

LIED, E. Determination of protein digestibility in Atlantic cod (Gadus morhua) with internal and external indicators. Canadian Journal Fish Aquatical Science, v.39, p.854-861, 1982.

LOSORDO, T.M. Recirculating Aquaculture Production Systems: The Status and the Future. Aquaculture Magazine, v.24, p.38-45, 1998. 
LOVELL, R.T. Canola meal in catfish feeds. Aquaculture Magazine, v.5, p.68-70, 1989.

LOVELL, R.T. Nutrition and Feeding of Fish. Boston: Kluwer Academic Publishers. 1998.

LOVELL, R.T. Nutrition and Feeding of Fish. New York, USA: Van Nostrand Reinhold, 1989.

LOVSHIN, L.L.; RUSHING, J.H. Acceptance by largemouth bass fingerlings of pelleted feed with a gustatory additive. The Progressive of Fish Culturist, v.51 p.73-78, 1989.

LUSAS, E. Replacement of animal proteins by defatted and full-fat soybean meals in aquaculture feeds. In: CHANG, Y.K; WANG, S.S. Advances in Extrusion Technology. Lancaster: Technomic Publ., 1999. p.167-177.

MAFFI, G.L. Graxarias e subprodutos. In: CONFERENCIA APINCO DE CIÊNCIA E TECNOLOGIA AVÍCOLAS. Chapecó, 1993. Anais. São Paulo: FACTA, 1993. p. 191-193.

MAMBRINI, M. ; ROEM, A. J. ; CRAVÉDI, J. P. ; LALLÉS, J.P.; KAUSHIK, S.J. Effects of replacing fish meal with soy protein concentrate and of Dl-methionine supplementation in high-energy, extruded diets on the growth and nutrient utilization of rainbow trout, Oncorhynchus mykiss. Journal of Animal Science. v.77, p.2990-2999, 1999.

MAMBRINI, M.; KAUSHIK, S.J. Indispensable amino acid requirements of fish: correspondence between quantitative data and amino acid profiles of tissue proteins. The Journal of Applied Ichthyology, v.11, p.24-247, 1995.

MAYNARD, L.A.; LOOSLY, J.K. Animal Nutrition. New York: McGraw-Hill, 1969. p.56. 
McGOOGAN, B.B.; GATLIN III, D.M. Effects of replacing fish meal with soybean meal in diets for red drum Sciaenops ocellatus and potential for palatability enhancement. Journal of the World Aquaculture Society, v.28, n.4, p.374-385, 1997.

McGOOGAN, B.B.; REIGH, R.C. Apparent digestibility of selected ingredients in red drum (Sciaenops ocellatus) diets. Aquaculture, v.141, p.233-244, 1996.

MEYERS, S. P. Aquaculture: current status and future developments. In: CHANG, Y.K; WANG, S.S. Advances in Extrusion Technology. Lancaster: Technomic Publ., 1999. p.3-10.

MILLIKIN, M.R. Effects of dietary protein concentration on growth, feed efficiency, and body composition of age- 0 striped bass. Transactions of the American Fisheries Society, v.111, p.373-378, 1982.

MILLIKIN, M.R. Interactive effects of dietary protein and lipid on growth and protein utilization of age- 0 striped bass. Transactions of American Fisheries Society, v.112, p.185-193, 1983.

MILLWARD, D. J. The nutritional regulation of muscle growth and protein turnover. Aquaculture, v.79, p.1-28, 1989.

MINISTÉRIO DA AGRICULTURA E ABASTECIMENTO. Compêndio Brasileiro de Alimentação Animal. Brasília: Departamento de Fiscalização e Fomento Animal, 1998.

MOON, H.Y.; GATLIN III, D.M. Total sulfur amino acid requirement of juvenile red drum, Sciaenops ocellatus. Aquaculture, v.95, p.97-106, 1991.

MOORE, S. On the determination of cystine as cysteic acid. Journal of Biology Chemistry, v.238, p.235-237, 1963.

MOORE, S. On the determination of cystine as cysteic acid. Journal of Biology Chemistry, v.238, p.235-237, 1963. 
MORALES, A.E.; CARDENETE, G.; DE LA HIGUERA, M.; SANZ, A. Effects of dietary protein source on growth, feed conversion and energy utilization in rainbow trout, Oncorhynchus mykiss. Aquaculture, v.124, p.117-126, 1994.

MOUAWAD, A. No sul do país: boas opções para a pesca do bass. Bíblia do Pescador, a.13, n.13, p.122-130. 1996.

MU, Y.Y.; LAM, T.J.; GUO, J.Y.; SHIM, K.F. Protein digestibility and amino acid availability of several protein sources for juvenile Chinese hairy crab Eriocheir sinensis H. Milne-Edwards (Decapoda, Grapsidae). Aquaculture Research, v.31, p.757-765, 2000.

MUROGA, K.; HIGASHI, M.; KEITOKU, H. The isolation of intestinal microflora of farmed red seabream (Pagrus major) and black seabream (Acanthopagrus schelegeli) at larval and juvenile stages. Aquaculture, v.65, p.79-88, 1987.

NATIONAL RESEARCH COUNCIL Nutrient Requirement of Coldwater Fishes. Washington: National Academic Press, 1981. 75p.

NATIONAL RESEARCH COUNCIL Nutrient Requirement of Fish. Washington: National Academic Press, 1993. 105p.

NATIONAL RESEARCH COUNCIL Nutrient Requirement of Trout, Salmon and Catfish. Washington: National Academic Press, 1977. 57p.

NAYLOR, R.L.; GOLDBURG, R.J.; PRIMAVERA, J.H.; KAUTSKY, N.; BEVERIDGE, M.C.M.; CLAY, J.; FOLKE, C.; LUBCHENCO, J.; MOONEY, H.; TROELL, M. Effect of aquaculture on world fish supplies. Nature, v.405, n.29, p.1017-1024, 2000.

NELSON, D.L.; COX, M.M. Lehninger Principles of Biochemistry. New York: Worth Publ., 2000. 145p. 
Ng, W.K.; HUNG, S.S.O. Estimating the ideal dietary essential amino acid pattern for growth of white sturgeon, Acipenser transmontanus (Richardson). Aquaculture nutrition, v.1, p.85-94, 1995.

NORDRUM, S.; ÅSHILD, K.; RØSJØ, C.; OLLI, J.J.; HOLM, H. Effects of methionine, cysteine and medium chain triglycerides on nutrient digestibility, absoption of amino acids along the intestinal tract and nutrient retention in Atlantic salmon (Salmo salar L.) under pair-feeding regime. Aquaculture, v.186, p.341-360, 2000 .

NOSE, $T$. On the metabolic fecal nitrogen in young rainbow trout. Bulletin Freshwater Fish, v.17, n.2, p.97-105, 1967.

NOSE, T. Summary report on the requirements of essential amino acids for carp. In: HALVER, J.E.; TIEWS, K. (Ed.) Finfish Nutrition and Fishfeed technology. Berlin: Heenemmann, 1979. p.145-156.

OGATA, H.; ARAI, S.; NOSE, T. Growth responses of cherry salmon, Oncorhynchus masou, and amigo salmon, O. rhodurus, fry fed purified casein diets supplemented with amino acids. Bulletin of Japanese Science Fisheries, v.49, p.1381-1385, 1983.

OGINO, C. Requirements of carp and rainbow trout for essential amino acids. Bulletin of Japanese Society of Scientific Fisheries, v.42, p.71-75, 1980.

OZÓRIO, R.O.A.; UKTOSEJA, J.L.A.; HUISMAN E.A.; VERRETH J.A.A. Changes in fatty acid concentrations in tissues of African catfish, Clarias gariepinu, Burchell, as a consequence of dietary carnitine, fat and lysine supplementation. British Journal of Nutrition, v.86 (in press), 2001.

PAGE, J.W.; ANDREWS, J.W. Interactions of dietary levels of protein and energy on channel catfish (Ictalurus punctatus). Journal of Nutrition, v.103, p.1339$1346,1973$. 
PARSONS C.M.; BAKER, D.H. The concept and use of ideal proteins in the feeding of non ruminants. In: REUNIÃO ANUAL DA SOCIEDADE BRASILEIRA DE ZOOTECNIA, 31., Maringá, 1994. Anais. Maringá: SBZ, 1994. p.119-128.

PFEFFER, E.; KINZINGER, S.; RODENHUTSCORD, M. Influence of the proportion of poultry slaughter by-products and of untreated or hydrothermically treated legume seeds in diets for rainbow trout, Oncorhynchus mykiss (Walbaum), on apparent digestibilities of their energy and organics components. Aquaculture Nutrition, v.1, p.111-117, 1995.

PIKE, I. Future role of fish meal and oil in salmon diets. Salmon News, v.4, n..5, p.3-5, 1996.

PORTZ, L.; CYRINO, J.E.P.; MARTINO, R.C. Growth and body composition of juvenile largemouth bass Micropterus salmoides in response to dietary protein and energy levels. Aquaculture Nutrition, v.7, (in press), 2001.

RAVI, J.; DEVARAJ, K.V. Quantitative essential amino acid requirements for growth of catla, Catla catla (Hamilton). Aquaculture, v.96, p.281-291, 1991.

REFSTIE, S.; HELLAND, S.J.; STOREBAKKEN, T. Adaption to soybean meal diets for rainbow trout, Oncrohynchus myliss. Aquaculture, v.153, p.263-272, 1997.

REFSTIE, S.; STOREBAKKEN, T.; ROEM, A.J. Feed comsuption and conversion in Atlantic salmon (Salmo salar) fed diets with fish meal, extracted soybean meal or soybean meal with reduced content of oligosaccharides, trypsin inhibitors, lectin and soya antigens. Aquaculture, v.162, p.301-312, 1998.

RINGØ, E. Does chromic oxide $\left(\mathrm{Cr}_{2} \mathrm{O}_{3}\right)$ affect faecal lipid and intestinal basterial flora in Arctic charr, Salvelinus alpinus. Aquaculture Fisheries Management, v.24, p.767-776, 1993.

RINGØ, E.; STRØM, E.; TABACHEK, J-A. Intestinal microflora of salmonids: a review. Aquaculture Research, v.26, p.773-789, 1995. 
ROBINSON, E.H.; WILSON, R.P. Arginine requirement and apparent absence of a lysine-arginine antagonist in fingerling channel catfish. Journal of Nutrition, v.111, p.46-52, 1981.

ROBINSON, E.H.; WILSON, R.P.; POE, W.E. Total aromatic amino acid requirement, phenylalanine requirement and tyrosine replacement value for fingerling channel catfish. Journal of Nutrition, v.110, p.1805-1812, 1980.

RODEHUTSCORD, M.; BORCHERT, F.; GREGUS, Z.; PACK, M.; PFEFFER, E. Availability and utilisation of free lysine in rainbow trout (Oncorhynchus mykiss) 1. Effect of dietary crude protein level. Aquaculture, v.187, p.163-176, 2000.

RODEHUTSCORD, M.; PFEFFER, E. Effects of supplemental microbial phytase on phosphorus digestibility and utilization in rainbow trout (Oncorhynchus mykiss). Water Science and Technology, v.31, p.143-147, 1995.

RUMSEY, G.L.; HUGHES, S.G.; WINFREE, R.A. Chemical and nutritional evaluation of soya protein preparations as primary nitrogen sources for rainbow trout (Oncorhynchus mykiss) Journal of Animal Feed Science of Technology, v.40, p.135-151, 1993.

RUMSEY, G.L.; KETOLA, H.G. Amino acid supplementation of casein diets of Atlantic salmon (Salmo salar) fry and of soybean meal for rainbow trout (Salmo gairdnerii) fingerlings. Journal of Fisheries Research Board Canadian, v.32, p.422-426, 1975.

RUMSEY, G.L.; PAGE, J.W.; SCOTT, M.L. Methionine and cystine requirements of rainbow trout. The Progressive Fish Culturist, v.45, p.139-143, 1983.

SADIKU, S.O.; JAUNCEY K. Digestibility, apparent amino acid availability and waste generation potential of soybean flour: poultry meat meal blend based diets for tilapia, Oreochromis niloticus (L.), fingerlings. Aquaculture Research, v.26, p.651-657, 1995. 
SAMANTARY, K.; MOHANTY, S.S. Interactions of dietary levels of protein and energy on fingerling snakehead, Channa striata. Aquaculture, v.156, p.241$249,1997$.

SANTIAGO, C.B.; LOVELL, R.T. Amino acid requirements for growth of Nile tilapia. Journal of Nutrition, v.118, p.1540-1546, 1988.

SANTOS, G.B.; MAIA-BARBOSA, P.M.; VIEIRA, F.; LOPEZ, C.M. Fish and zooplankton community structure in reservoirs of Southeastern Brazil: Effects of the introduction of exotic predatory fish. In: PINTO-COELHO, R.M.; GIANI, A.; VON SPERLING, E. (Ed.). Reservoirs in Minas Gerais with Special References to Future Development and Management Strategies. Belo Horizonte: Universidade Federal de Minas Gerais. p.155-132. 1994.

SARGENT, J.; HENDERSON, R.J.; TOCHER, D.R. The lipids. In: HALVER, J. (Ed.) Fish Nutrition. Washington: Academic Press, 1989. cap.4, p.153-217.

SAS INSTITUTE. SAS User's Guide: Statistics. 5.ed. Cary, 1985.

SCORVO FILHO, J.D.; AYROSA, L.M.S. São Paulo: A situação da piscicultura no Estado. Panorama da Aquicultura, v.6, n.35, p.18-19, 1996.

SCOTT, M.L.; NESHEIM, M.C.; YOUNG, R.J. Feedstuffs for poultry. In: SCOTT, M.L.; NESHEIM, M.C.; YOUNG, R.J. (Ed.). Nutrition of the Chicken. New York: M.L. Scott and Associates, 1982. p.431-549.

SCHÄFER, A.; KOPPE, W.M.; MEYER-BURGDORFF, K.H.; GÜNTHER, K.D. Effects of a microbial phytase on the utilization of native phosphorus by carp in a diet based on soybean meal. Water Science and Technology, v.31, p.149-155, 1995.

SEIM, W.K; BOYD, C.E.; DIANA; J.S. Environmental considerations. In: EGNA, H.S.; BOYD, C.E. (Ed.). Dynamics of Pond Aquaculture. Boca Ratón: CRC Press, Inc., 1997. p.179-182. 
SHIAU, S.Y.; CHEM, M.J. Carbohydrate utilization of tilapia (Oreochromis niloticus $\mathrm{x} O$. aureus) as influenced by different chromium sources. Aquaculture, v.123, p.1747-1753, 1993.

SHIAU, S.Y; LIANG, H-S. Carbohydrate utilization and digestibility by Tilapia, Oreochromis niloticus $\mathrm{X} O$. aureus, are affected by chromic oxide inclusion in the diet. Journal of Nutrition, v.125, p.976-983, 1995.

SHIAU, S.Y.; SHY, S.M. Dietary chromic oxide inclusion level required to maximize glucose utilization in hybrid tilapia, Oreochromis niloticus $\mathrm{x} O$. aureus. Aquaculture, v.161, p.357-364, 1998.

SHIAU, S.Y; LIN, S.F. Effect of supplemental dietary chromium and vanadium of the utilization of different carbohydrate in tilapia, Oreochromis niloticus $\mathrm{x} O$. aureus. Aquaculture, v.110, p.321-330, 1993.

SHIAU, S-Y; LIANG, H-S. Carbohydrate utilization and digestibility by tilapia, Oreochromis niloticus $\mathrm{x} O$. aureus, are affected by chromic oxide inclusion in the diet. Journal of Nutrition, v.125, p.976-983, 1995.

SIDRANSKY, H.; VERNEY, E.; MURTY, C.N. Effect of elevated dietary tryptophan on protein synthesis in rat liver. Journal of Nutrition, v.111, n.11, p.1942-1948, 1981.

SLOANE, M.B. Performance of training and grow-out diets for largemouth bass. Alabama, 1993. 66.p M.S. (Thesis) - Auburn University.

SMALL, B.C.; AUSTIC, R.E.; JOSEPH Jr., H.S. Amino acid availability of four practical feed ingredients fed to striped bass Morone saxatilis. Journal of the World Aquaculture Society, v.30, n.1, p.58-64, 1999.

SMALL, B.C.; SOARES JR, J.H. Estimating the quantitative essential amino acid requirements of striped bass Morone saxatilis, using fillet $\mathrm{A} / \mathrm{E}$ ratios. Aquaculture Nutrition, v.4, p.225-232, 1998. 
SMITH, B.W.; LOVELL, R.T. Determination of apparent protein digestibility in feeds for channel catfish. Transactions of the American Fisheries Society, v.102, n.4, p.831-835, 1973.

SMITH, B.W.; LOVELL, R.T. Digestibility of nutrients in semipurifed rations by channel catfish in stainless steel troughs. Proceedings Annual Conference Southeast Association Game Fish Community, v.25, p.425-459, 1971.

SMITH, R.R. Nutritional energetics. In: HALVER J. E. (Ed.) Fish Nutrition. Washington: Academic Press, 1989. p.8-17.

SMITH, R.R.; PETERSON, M.C.; ALEED, A.C. Effect of leaching on apparent digestion coefficients of feedstuffs for salmonids. The Progressive Fish Culturist, v.42, n.4, p.195-199, 1980.

SNOW, J.R. An exploratory attempt to rear largemouth black bass fingerlings in a controlled environment. In: ANNUAL MEETING OF THE SOUTHEASTERN ASSOCIATION OF GAME AND FISH COMMISSIONERS, 17., Mississippi, 1960. Proceedings. Mississippi: Biloxi, 1960, p.253-257.

SNOW, J.R. Results of further experiments on rearing largemouth bass fingerlings under controlled conditions. In: ANNUAL CONFERENCE OF THE SOUHTEASTERN ASSOCIATION OF GAME AND FISH COMMISSIONERS, 17., Arkansas, 1963. Proceedings. Arkansas: Hot Springs, 1963. p.191-203.

SPYRIDAKIS, R.; METAILlER, R.; GABAUDAN, J.; RIAZA, A. Studies on nutrient digestibility in European sea bass (Dicentrarchus labrax). I. Methodological aspects concerning faeces collection. Aquaculture, v.77, p.61$70,1989$.

STEFFENS, W. Principles of Fish Nutrition. Chichester, England, UK: Ellis Harwood, 1989. p. 184-208. 
STONE, D.A.J.; ALLAN, G.L.; PARKINSON, S.; ROWLAND, S.J. Replacement of fish meal in diets for Australian silver perch, Bidyanus bidyanus III. Digestibility and growth using meat meal products. Aquaculture, v.186, p.311326,2000 .

STOREBAKKEN, T.; SHEARER, K.D.; BAEVERFJORD, G.; NIELSEN, B.G.; ÅSGÅRD, T.; SCOTT, T.; De LAPORTE, A. Digestibility of macronutrients, energy and amino acids, absorption of elements and absence of intestinal enteritis in Atlantic salmon, Salmo salar, fed diets with wheat gluten. Aquaculture, v.184, p.115-132, 2000.

STOREBAKKEN, T.; SHEARER, K.D.; ROEM, A.J. Availability of protein, phosphorus and other elements in fish meal, soy protein concentrate and phytatetreated soy protein concentrate based diets to Atlantic salmon, Salmo salar. Aquaculture, v.161, p.365-379, 1998.

SUGITA, H.; MIYAJIMA, C.; FUKUMOTO, M.; KOYAMA, H.; DEGUCHI, Y. Effect of oxolinic acid on fecal microflora of gold-fish (Carassius auratus). Aquaculture, v.80, p.163-174, 1989.

SUGITA, H.; MIYAJIMA, C; DEGUCHI, Y. The vitamin $\mathrm{B}_{12-}$ producing ability of the intestinal microflora of freshwater fish. Aquaculture, v.92, p.267-276, 1991.

SUGITA, H.; TSUNOHARA, M.; FUKUMOTO, M.; DEGUCHI, Y. Comparison of microflora between intestinal contents and fecal pellets of freshwater fishes. Nippon Suisan Gakkaishi, v.53, p.287-290, 1987.

SUGIURA, S.H.; DONG, F.M.; HARDY, R.W. Effect of dietary supplements on the availability of mineral in fish meal: preliminary observation. Aquaculture, v. 160, p.283-303, 1998.

SULLIVAN, J.A; REIGH, R.C. Apparent digestibility of selected feedstuffs in diets for hybrid striped bass (Morone saxatilis x Morone chrysops). Aquaculture, v.138, p.313-322, 1995. 
TACON G.J.; DOMINI, W.G. Overview of world aquaculture and aquafeed production. In: WORLD OF AQUACULTURE, 26., Sidney, 1999. Proceedings. Baton Rouge, 1999. p.853.

TACON, A.G J.; COWEY C.B. Protein and amino acid requirement. In: TYTLER, P.; CALOW, P. Fish Energetics: new perspectives. London: Croom Helm, 1985. p.155-193.

TACON, A.G.J Contribution to Food Fish Supplies. Food fish supplies $<$ www.fao.org $>(06 / 07 / 2001)$.

TACON, A.G.J. Feeding tomorrow's fish. World Aquaculture, v.27, p.20-32, 1996.

TACON, A.G.J. Standard Methods for the Nutrition of Farmed Fish and Shrimp. Washington: Argent Laboratories Press, 1990. p.2-20.

TACON, A.G.J. Feed ingredients for carnivorous fish species. Alternatives to fish meal and other fisheries resources. FAO Fisheries Circular FAO, Rome. n. 881, 35 p., 1994.

TACON, A.G.J.; DE SILVA, S.S. Feed preparation and feed management strategies within semi-intensive fish farming systems in the tropics. Aquaculture, v.151, p.379-404, 1997.

TACON, A.G.J.; RODRIGUES, A.M.P. Comparison of chromic oxide, crude fiber, polyethylene and acid-insoluble ash as dietary markers for the estimation of apparent digestibility coefficients in rainbow trout. Aquaculture, v.43, p.391$399,1984$.

TAKEUCHI, T. Laboratory work - chemical evaluations of dietary nutrients. In: WATANABE, T. Fish Nutrition and Mariculture. Tokyo: Aquatic Biosciences, 1988. Cap.3, p.179-233. 
THEBAUld, H.; ALliot, E.; PASTOUREAUD, A. Quantitative methionine requirement of juvenile sea bass (Dicentrarchus labrax). Aquaculture, v.50, p.75-87, 1985.

THODESEN, J.; STOREBAKKEN, T. Digestibility of diets with precooked rye or wheat by Atlantic salmon, Salmo salar, L. Aquaculture Nutrition, v.4, p.123126, 1998.

TIBALDI, E.; LANARI, D. Optimal dietary lysine levels for growth and protein utilization of fingerling sea bass (Dicentrarchus labrax L.) fed semi purified diets. Aquaculture, v.95, p.297-304, 1991.

TIBALDI, E.; TULLI, F.; LANARI, D. Arginine requirement and effect of different dietary arginine and lysine levels for fingerling sea bass (Dicentrarchus labrax). Aquaculture, v. 127, p.2017-218, 1994.

TIDWELL, J.H.; WEBSTER, C.D.; COYLE, S.D. Effects of dietary protein level on second year growth and water quality for largemouth bass (Micropterus salmoides) raised in ponds. Aquaculture, v.145, p. 213-223, 1996.

VAL, A.L.; ROLIN, P.R.; RABELO, H. Situação atual da aqüicultura na região norte. In: VALENTI, W.C.; POLI, C.R.; PEREIRA, J.A.; BORGHETTI, J.R. Aqüicultura no Brasil. Brasília: CNPq/Ministério da Ciência e Tecnologia, 2000. p.247-266.

VALENTI, W.C. Aquaculture for sustainable development. In: VALENTI, W.C.; POLI, C.R.; PEREIRA, J.A.; BORGHETTI, J.R. Aqüicultura no Brasil. Brasília: CNPq/Ministério da Ciência e Tecnologia, 2000. p.17-24.

VENS-CAPPELL, B. Methodical studies on digestion in trout. 1. Reliability of digestion coefficients in relation to methods for faeces collection. Aquaculture Engineering, v.4, p.33-49, 1985. 
WALTON, M.J.; COLOSO, R.M.; COWEY, C.B.; ADRON, J.W.; KNOX, D. The effect of dietary tryptophan levels on growth and metabolism of rainbow trout (Salmo gairdneri). British Journal of Nutrition, v.51, p.279-287, 1984.

WANG, T.C.; FULLER, M.F. The optimum dietary amino acid pattern for growing pigs. 1. Experiments by amino acid deletion. British Journal of Nutrition, v.62, p.77-89, 1989.

WATANABE, T. Fish nutrition. In: TAKEUCHI, T. Fish Nutrition and Mariculture. Tokyo: Aquatic Biosciences, 1988. cap.1, p.179-233.

WEATHERUP, R.M.; McCRACKEN, K.J. Comparision of estimates of digestibility of two diets for rainbow trout Oncorhynchus mykiss (Walbaum), using two markers and two methods of feaces collection. Aquaculture Research, v.29, p.527-533, 1998.

WEBSTER C. D. ; THOMPSON, K. R.; MORGAN, A. M.; GRISBY, E. J.; GANNAM, A. L. Use of hempseed meal, poultry by-product meal, and canola meal in practical diets without fish meal for sunshine bass (Morone chrysops $x$ M. saxatilis). Aquaculture. v. 188, p. 299-309, 2000.

WEBSTER C.D.; TIDWELL J.H.; GOODGAME, L.S.; YANCEY, D.H.; MACKEY, L. Use of soybean meal and distillers grains with solubles as partial or total replacement of fish meal in diets for channel catfish Ictalurus punctatus. Aquaculture, v.106, p.301-309, 1992.

WEBSTER, C.D. ; GOODGAME - TIU ,L.S. ; TIDWELL, J.H. Total replacement of fish meal by soy bean meal, with various percentages of supplemental Lmethionine, in diets for blue catfish, Ictalurus furcatus (Lesueur). Aquaculture Research,. v. 26, p. 299-306, 1995.

WEBSTER, C.D., TIU, L.G., MORGAN, A.M. Effect of partial and total replacement of fish meal on growth and body composition of Sunshine Bass Morone chrysops x $M$. saxatilis fed practical diets. Journal of the World Aquaculture Society. v. 30, n. 4, 443-453, 1999. 
WEBSTER, C.D.; TIU, L.G.; TIDWELL, J.H. Effects of replacing fish meal in diets on growth and body composition of palmetto bass (Morone saxatilis $\mathrm{x}$ Morone chrysops) raised in cages. Journal of Applied Aquaculture, v.7, n.1, p.53-67, 1997.

WEE, K.L.; TACON, A.G.J. A preliminary study on the dietary protein requirement of juvenile snakehead. Bulletin of Japanese Society of Scientific Fisheries, v.48, p. 1463-1468, 1982.

WILSON, R.E.; ROBINSON, E.H.; POE, W.E. Apparent and true availability of aminoacids from common feed ingredients for channel catfish. Journal of Nutrition, v.111, p.923-929, 1981.

WILSON, R.P. Amino acids and proteins. In: HALVER, J.E. (Ed.). Fish Nutrition. London: Academic Press, 1989. cap.3, p.111-151.

WILSON, R.P. Handbook of nutrient requirements of fish. In: HALVER, J.E. Fish Nutrition. San Diego, California, USA: Academic Press Inc., 1991. p.161-168.

WILSON, R.P.; COWEY, C.B. Amino acid composition of whole body tissue of rainbow trout and Atlantic salmon. Aquaculture, v.48, p.373-376, 1985.

WILSON, R.P.; POE, W.E. Relationship of whole body and egg essential amino acid patterns in channel catfish, Ictalurus punctatus. Comparative Biochemistry and Physiology, v.80B, p.385-389, 1985.

WINDELL, J.R.; FOLITZ, J.W.; SAROKON, J.P. Methods of fecal collection and nutrient leaching in digestibility studies. The Progressive Fish Culturist, v.40, p.51-55, 1978.

WOOD, L.C.; SOARES, J.H. Nutritional requirements of domestic striped bass broodstock. In: WORLD FISHERIES CONGRESS, 2., Australia, 1996. Proceedings. Australia: Brisbane, 1996. p.107. 
WU, G.; MORRIS, S.M. Arginine metabolism: nitric oxide and beyond. Journal of Biochemistry, v.336, p.1-17, 1998.

YEHUDA, Y.; DEGANI, G.; VIOLA, S. The digestibility of nutrient sources for common carp, Cyprinus carpio Linnaeus. Aquaculture Research, v.28, p.575$580,1997$.

ZEITOUN, I.H.; UllREY, D.E.; HALVER, J.E.; TACK, P.I.; MAGEE, W.T. Influence of salinity on protein requeriments of coho salmon (Oncorhynchus kisutch) smolts. Journal of Fisheries Research Board Canadian, v.31, p.11451148, 1974. 